Prepared in cooperation with the Bureau of Land Management

\title{
Assessment of Soil and Water Resources in the Organ Mountains-Desert Peaks National Monument, New Mexico
}



Scientific Investigations Report 2019-5142 
Cover photograph. Organ Mountains in south-central New Mexico. Photograph courtesy of Bob Wick, Bureau of Land Management. File:Organ Mountains WSA (9472360902).jpg. (2017, February 19). Wikimedia Commons, the free media repository, accessed February 3, 2020, at https://commons.wikimedia.org/w/index.php?title=File:Organ_Mountains_WSA_(9472360902).jpg\&oldid=234168871. 


\section{Assessment of Soil and Water Resources in the Organ Mountains-Desert Peaks National Monument, New Mexico}

By Johanna M. Blake, Aurelia C. Mitchell, Zachary Shephard, Grady Ball, Shaleene Chavarria, and Kyle R. Douglas-Mankin

Prepared in cooperation with the Bureau of Land Management

Scientific Investigations Report 2019-5142 


\title{
U.S. Department of the Interior DAVID BERNHARDT, Secretary
}

\author{
U.S. Geological Survey \\ James F. Reilly II, Director
}

\section{U.S. Geological Survey, Reston, Virginia: 2020}

For more information on the USGS - the Federal source for science about the Earth, its natural and living resources, natural hazards, and the environment-visit https://www.usgs.gov or call 1-888-ASK-USGS.

For an overview of USGS information products, including maps, imagery, and publications, visit https://store.usgs.gov.

Any use of trade, firm, or product names is for descriptive purposes only and does not imply endorsement by the U.S. Government.

Although this information product, for the most part, is in the public domain, it also may contain copyrighted materials as noted in the text. Permission to reproduce copyrighted items must be secured from the copyright owner.

Suggested citation:

Blake, J.M., Mitchell, A.C., Shephard, Z., Ball, G., Chavarria, S., and Douglas-Mankin, K.R., 2020, Assessment of soil and water resources in the Organ Mountains-Desert Peaks National Monument, New Mexico: U.S. Geological Survey Scientific Investigations Report 2019-5142, 64 p., https://doi.org/10.3133/sir20195142.

Associated data for this publication:

Mitchell, A.C., Shephard, Z.M., Blake, J.M., Ball, G.P., Chavarria, S.B., and Douglas-Mankin, K.R., 2019, Database associated with the assessment of soil and water resources in the Organ Mountains-Desert Peaks National Monument: U.S. Geological Survey data release, https://doi.org/10.5066/P9JVHA4Z.

ISSN 2328-0328 (online) 


\section{Acknowledgments}

This study was conducted in cooperation with the Bureau of Land Management. The authors thank the following Bureau of Land Management employees for their assistance with this study: Ray Hewitt, Mara Weisenberger, Marilyn Walker Cunningham, Gordon Michaud, Colin Dunn, Corey Durr, Patrick Alexander, William Childress, Jesarey Barela, Jennifer Montoya, and John Barnitz, Jr. 


\section{Contents}

Acknowledgments ....................................................................................................................ii

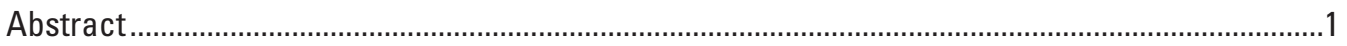

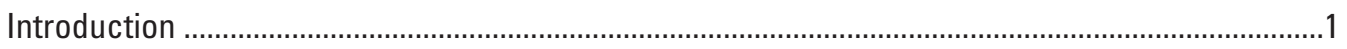

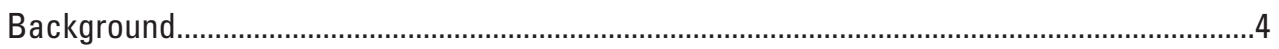

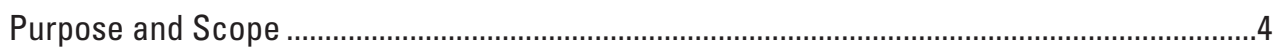

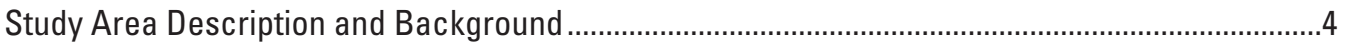

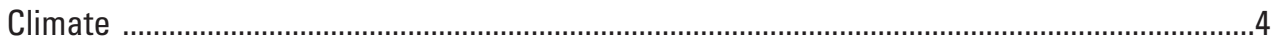

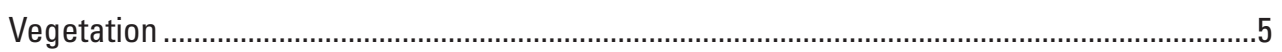

Soils

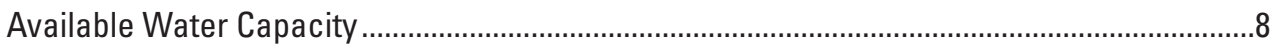

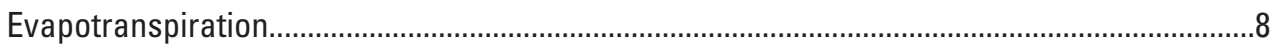

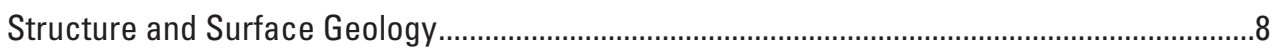

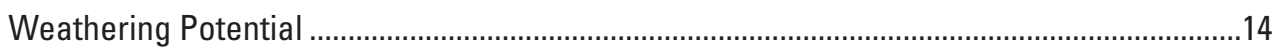

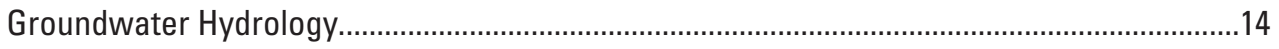

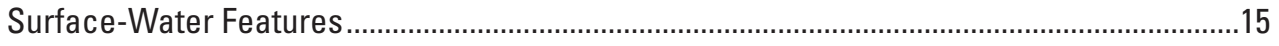

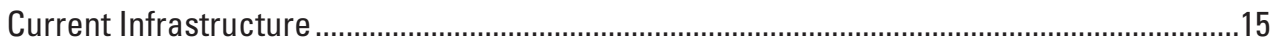

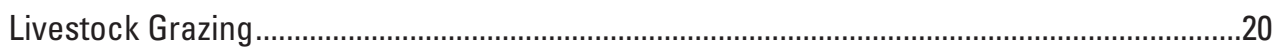

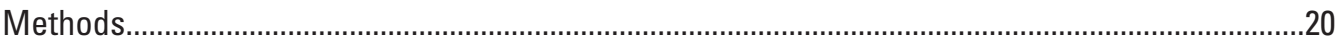

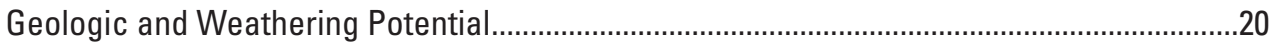

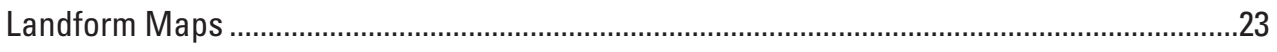

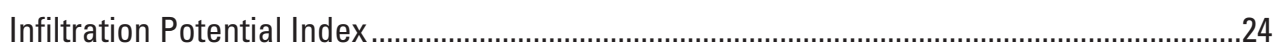

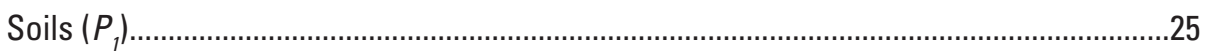

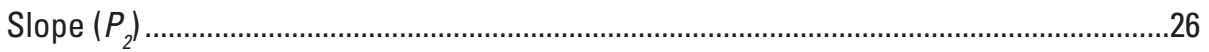

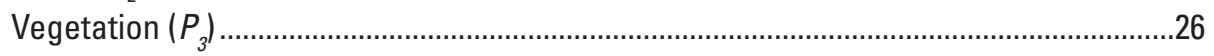

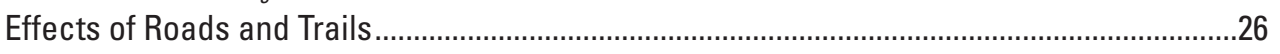

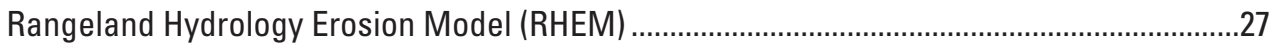

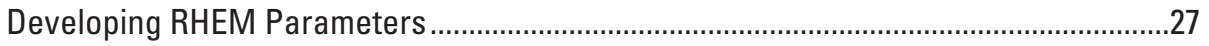

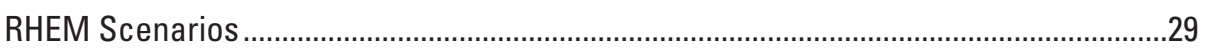

Scenario 1: Baseline Conditions, 2016 ................................................................29

Scenario 2: Vegetation Sensitivity Analysis-20-Percent Increase in Vegetation Cover 30

Scenario 3: Vegetation Sensitivity Analysis-20-Percent Decrease in Vegetation

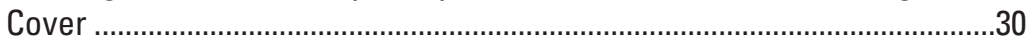

Scenario 4: Drought, Heavy Grazing, or Land-Use Pressure ...................................30

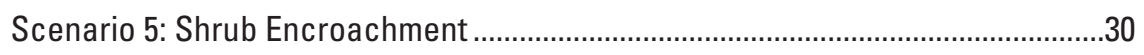

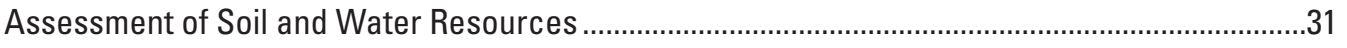

Assessment of Geology and Weathering Potential ..............................................................

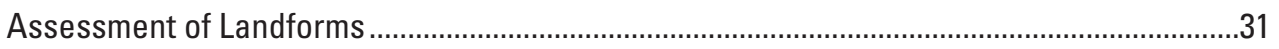

Assessment of Infiltration Potential Across the Landscape .....................................................33

Assessment of Runoff and Erosion Across the Landscape-RHEM Results...........................44

Estimated Runoff from RHEM Scenarios .......................................................................

Simulated Soil Loss and Runoff from RHEM Scenarios ...................................................49

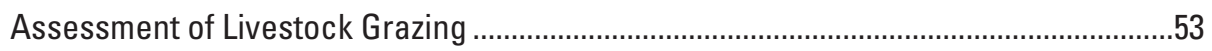

Assessment of Arroyo Location and Infiltration Potential ........................................................53 


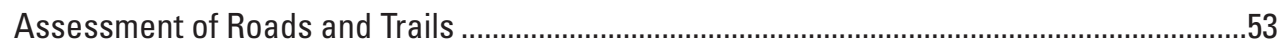

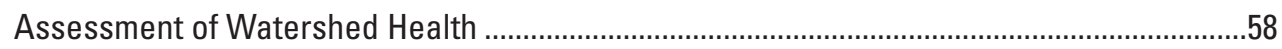

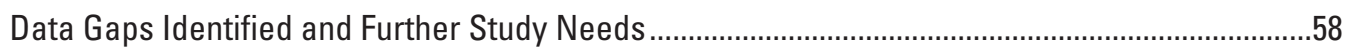

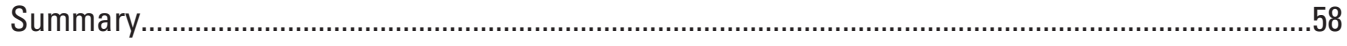

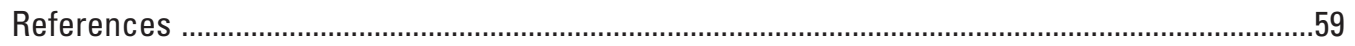

\section{Figures}

1. Map showing the location of the Organ Mountains-Desert Peaks National Monument subunits, New Mexico...

2. Map showing land administered by the Bureau of Land Management within and surrounding the Organ Mountains-Desert Peaks National Monument, New Mexico .....3

3. Map showing vegetation macrogroups in the Organ Mountains-Desert Peaks National Monument, New Mexico.

4. Map showing the total percentage of vegetation cover within and surrounding the Organ Mountains-Desert Peaks National Monument, New Mexico.

5. Map showing soil texture classes in the Organ Mountains-Desert Peaks National Monument, New Mexico, according to the Natural Resources Conservation Service soil survey.

6. Map showing available water capacity of soils in the Organ Mountains-Desert Peaks National Monument, New Mexico.

7. Average evapotranspiration rates for 2015, Organ Mountains-Desert Peaks National Monument, New Mexico

8. Map showing the geology of the area within and surrounding the Organ Mountains-Desert Peaks National Monument, New Mexico

9. Map showing U.S. Geological Survey and New Mexico Office of the State Engineer wells and test holes near the Organ Mountains-Desert Peaks National Monument, New Mexico.

10. Map showing locations of surface-water features in and near the Organ Mountains-Desert Peaks National Monument, New Mexico

11. Map showing recreational infrastructure for the Desert Peaks and Doña Ana subunits of the Organ Mountains-Desert Peaks National Monument, New Mexico .....18

12. Map showing recreational infrastructure for the Organ Mountains subunit of the Organ Mountains-Desert Peaks National Monument, New Mexico..

13. Map showing locations of grazing allotments and troughs in the Organ Mountains-Desert Peaks National Monument, New Mexico.

14. Map showing surface geology by major rock type for qualitative understanding of physical weathering potential in the Organ Mountains-Desert Peaks National Monument, New Mexico.

15. Maps showing distribution of potential for rock weathering in the Organ Mountains-Desert Peaks National Monument, New Mexico, based on five chemical weathering indices.

16. Hammond-Dikau method landforms map, Desert Peaks subunit, Organ Mountains-

Desert Peaks National Monument, New Mexico..

17. Geomorphon method landforms map, Desert Peaks subunit, Organ Mountains-

Desert Peaks National Monument, New Mexico...

18. Hammond-Dikau method landforms map, Doña Ana subunit, Organ MountainsDesert Peaks National Monument, New Mexico. 
19. Geomorphon method landforms map, Doña Ana subunit, Organ Mountains-

Desert Peaks National Monument, New Mexico.

20. Hammond-Dikau method landforms map, Organ Mountains subunit, Organ Mountains-Desert Peaks National Monument, New Mexico.

21. Geomorphon method landforms map, Organ Mountains subunit, Organ Mountains-Desert Peaks National Monument, New Mexico.

22. Hammond-Dikau method landforms map, Potrillo subunit, Organ MountainsDesert Peaks National Monument, New Mexico.

23. Geomorphon method landforms map, Potrillo subunit, Organ MountainsDesert Peaks National Monument.

24. Graph showing infiltration potentials for individual subunits and for the entire Organ Mountains-Desert Peaks National Monument, New Mexico

25. Graphs showing RHEM-simulated annual average runoff response to soil texture and total foliar cover and soil texture for 168,276 cells in the Organ Mountains-Desert Peaks National Monument, New Mexico.

26. Graphs showing Rangeland Hydrology and Erosion Model simulated annual average soil loss response to slope and soil texture and relation between slope and soil texture for 168,276 cells in the Organ Mountains-Desert Peaks National Monument, New Mexico.

27. Maps showing soil loss and change from baseline scenario, Organ MountainsDesert Peaks National Monument, New Mexico.

28. Maps showing soil loss and change from baseline scenario, Organ MountainsDesert Peaks National Monument, New Mexico.

29. Maps showing runoff and change from baseline scenario, Organ MountainsDesert Peaks National Monument, New Mexico.

30. Maps showing runoff and percent change from baseline scenario, Organ Mountains-Desert Peaks National Monument, New Mexico.

31. Map showing watering trough locations and baseline soil loss conditions simulated by the Rangeland Hydrology and Erosion Model, Organ MountainsDesert Peaks National Monument, New Mexico.

32. Map showing watering trough locations and baseline runoff conditions simulated by the Rangeland Hydrology and Erosion Model, Organ MountainsDesert Peaks National Monument, New Mexico.

33. Map showing location of arroyos of concern and infiltration potential in the Organ Mountains-Desert Peaks National Monument, New Mexico 56

34. Map showing location of major roads and roads within 300 feet of an ephemeral drainage in the Organ Mountains-Desert Peaks National Monument, New Mexico.....57

\section{Tables}

1. Vegetation macrogroups and common species within the Organ MountainsDesert Peaks National Monument, New Mexico, and the area covered by each macrogroup

2. Soil texture classes, area covered by each texture class, and percentage of total monument area covered by each texture class in the Organ MountainsDesert Peaks National Monument, New Mexico, according to the Natural Resources Conservation Service soil survey

3. Summary of data used in the assessment of soil and water resources in the Organ Mountains-Desert Peaks National Monument, New Mexico.

4. Common landforms found in the southwestern United States and their definitions ......24 
5. GRASS GIS geomorphons associated with common landforms.

6. Classification of the soils parameter in the infiltration potential index used to identify areas of relatively high or low land-surface infiltration potential in the Organ Mountains-Desert Peaks National Monument, New Mexico.

7. Classification of the slope parameter in the infiltration potential index used to identify areas of relatively high or low land-surface infiltration potential in the Organ Mountains-Desert Peaks National Monument, New Mexico.

8. Soil texture correspondence between RHEM and NRCS STATSGO/gSSURGO categories

9. Vegetation macrogroups in the Organ Mountains-Desert Peaks National Monument, areas covered by each, and number of plots used to develop RHEM parameters

10. Average percent foliar cover plus or minus standard deviations for plot data and ratios of each foliar category to total foliar cover by vegetation macrogroup ........30

11. Average percent ground cover plus or minus standard deviations for plot data by vegetation macrogroup

12. Multiple linear regression equations and statistics for estimating total foliar cover, litter cover, and rock cover as a function of selected independent variables

13. Summary of weathering indices ...

14. Slope percentage, cover percentage, soil loss, and runoff for the Organ Mountains-Desert Peaks National Monument, New Mexico, and for vegetation macrogroups with plots within the Monument. 


\section{Conversion Factors}

U.S. customary units to International System of Units

\begin{tabular}{lcl}
\hline & Multiply & \multicolumn{1}{c}{ To obtain } \\
\hline inch (in.) & Length & \\
inch (in.) & 2.54 & centimeter $(\mathrm{cm})$ \\
foot (ft) & 25.4 & millimeter $(\mathrm{mm})$ \\
mile (mi) & 0.3048 & meter $(\mathrm{m})$ \\
\hline & 1.609 & kilometer $(\mathrm{km})$ \\
\hline acre & Area & \\
acre & 4,047 & square meter $\left(\mathrm{m}^{2}\right)$ \\
acre & 0.4047 & hectare $($ ha) \\
acre & 0.4047 & square hectometer $\left(\mathrm{hm}^{2}\right)$ \\
square foot $\left(\mathrm{ft}^{2}\right)$ & 0.004047 & square kilometer $\left(\mathrm{km}^{2}\right)$ \\
square foot $\left(\mathrm{ft}^{2}\right)$ & 929.0 & square centimeter $\left(\mathrm{cm}^{2}\right)$ \\
square mile $\left(\mathrm{mi}{ }^{2}\right)$ & 0.09290 & square meter $\left(\mathrm{m}^{2}\right)$ \\
\hline & 2.590 & square kilometer $\left(\mathrm{km}^{2}\right)$ \\
\hline inch per hour $(\mathrm{in} / \mathrm{h})$ & Flow rate & \\
inch per year $(\mathrm{in} / \mathrm{yr})$ & 0.0254 & meter per hour $(\mathrm{m} / \mathrm{h})$ \\
\hline
\end{tabular}

International System of Units to U.S. customary units

\begin{tabular}{|c|c|c|}
\hline Multiply & By & To obtain \\
\hline \multicolumn{3}{|c|}{ Length } \\
\hline centimeter $(\mathrm{cm})$ & 0.3937 & inch (in.) \\
\hline millimeter $(\mathrm{mm})$ & 0.03937 & inch (in.) \\
\hline meter $(\mathrm{m})$ & 3.281 & foot $(\mathrm{ft})$ \\
\hline meter $(\mathrm{m})$ & 1.094 & yard (yd) \\
\hline \multicolumn{3}{|c|}{ Area } \\
\hline square meter $\left(\mathrm{m}^{2}\right)$ & 0.0002471 & acre \\
\hline hectare (ha) & 2.471 & acre \\
\hline square meter $\left(\mathrm{m}^{2}\right)$ & 10.76 & square foot $\left(\mathrm{ft}^{2}\right)$ \\
\hline hectare (ha) & 0.003861 & square mile $\left(\mathrm{mi}^{2}\right)$ \\
\hline \multicolumn{3}{|c|}{ Flow rate } \\
\hline meter per hour $(\mathrm{m} / \mathrm{h})$ & 39.37 & inch per hour (in/h) \\
\hline millimeter per year (mm/yr) & 0.03937 & inch per year (in/yr) \\
\hline \multicolumn{3}{|c|}{ Mass } \\
\hline metric ton $(\mathrm{t})$ & 1.102 & ton, short $[2,000 \mathrm{lb}]$ \\
\hline metric ton $(\mathrm{t})$ & 0.9842 & ton, long $[2,240 \mathrm{lb}]$ \\
\hline
\end{tabular}

Temperature in degrees Celsius $\left({ }^{\circ} \mathrm{C}\right)$ may be converted to degrees Fahrenheit $\left({ }^{\circ} \mathrm{F}\right)$ as ${ }^{\circ} \mathrm{F}=\left(1.8 \times{ }^{\circ} \mathrm{C}\right)+32$.

Temperature in degrees Fahrenheit $\left({ }^{\circ} \mathrm{F}\right)$ may be converted to degrees Celsius $\left({ }^{\circ} \mathrm{C}\right)$ as ${ }^{\circ} \mathrm{C}=\left({ }^{\circ} \mathrm{F}-32\right) / 1.8$. 


\section{Datum}

Vertical coordinate information is referenced to elevation, the height above the North American Vertical Datum of 1988 (NAVD 88).

Horizontal coordinate information is referenced to the North American Datum of 1983 (NAD 83).

Elevation, as used in this report, refers to the distance above the vertical datum.

\section{Abbreviations}

$\begin{array}{ll}> & \text { greater than } \\ < & \text { greater than or equal to } \\ \text { BLM } & \text { less than } \\ \text { CIA } & \text { Bureau of Land Management } \\ \text { CIW } & \text { chemical index of alteration } \\ \text { DEM } & \text { chemical index of weathering } \\ \text { ET } & \text { digital elevation model } \\ F_{t} & \text { evapotranspiration } \\ \text { GIS } & \text { friction factor } \\ \text { GNIS } & \text { geographic information system } \\ \text { gSSURG0 } & \text { Geographic Names Information System } \\ \text { HUC 10 } & \text { Gridded Soil Survey Geographic Database } \\ \text { IPI } & \text { hydrologic unit code 10 } \\ K_{e} & \text { infiltration potential index } \\ K_{\text {sat }} & \text { effective hydraulic conductivity } \\ K_{s s} & \text { saturated hydraulic conductivity } \\ \text { Monument } & \text { splash and sheet erosion factor } \\ \text { MWPI } & \text { Organ Mountains-Desert Peaks National Monument } \\ \text { NASA } & \text { modified weathering potential index } \\ \text { NDVI } & \text { National Aeronautics and Space Administration } \\ \text { NMOSE/ICE } & \text { normalized difference vegetation index } \\ \text { NOAA } & \text { New Mexico Office of the State Engineer/lnterstate Stream Commission } \\ \text { NRCS } & \text { National Oceanic and Atmospheric Administration } \\ \text { NWIS } & \text { Natural Resources Conservation Service } \\ R^{2} & \text { National Water Information System (USGS database) } \\ \text { RHEM } & \text { coefficient of determination } \\ \text { STATSG02 } & \text { U.S. General Soil Map dataset } \\ & \end{array}$




$\begin{array}{ll}\text { SSURGO } & \text { Soil Survey Geographic Database } \\ \text { UAS } & \text { unmanned aerial system } \\ \text { USDA } & \text { U.S. Department of Agriculture } \\ \text { USDA-ARS } & \text { U.S. Department of Agriculture, Agricultural Research Service } \\ \text { USGS } & \text { U.S. Geological Survey } \\ \text { USNVC } & \text { U.S. National Vegetation Classification } \\ \text { V } & \text { Vogt ratio } \\ \text { WCC } & \text { watershed condition classification } \\ \text { WEPP } & \text { Water Erosion Prediction Project } \\ \text { WIP } & \text { weathering index of Parker }\end{array}$




\title{
Assessment of Soil and Water Resources in the Organ Mountains-Desert Peaks National Monument, New Mexico
}

\author{
By Johanna M. Blake, Aurelia C. Mitchell, Zachary Shephard, Grady Ball, Shaleene Chavarria, and \\ Kyle R. Douglas-Mankin
}

\section{Abstract}

The Organ Mountains-Desert Peaks National Monument (Monument) in southern New Mexico was established in 2014. Given anticipated future demands in the Monument for recreation, livestock grazing, and maintenance of rights-ofway (for example, pipelines and powerlines), the Bureau of Land Management (BLM) needs a better understanding of the current soil and water resources and how infrastructure improvements could affect these resources and the watershed. Specifically, the BLM is concerned with infiltration and erosion and their relations to existing or planned infrastructure, such as roads, campgrounds, location of livestock grazing, and rights-of-way. Alternatives to the current land-use conditions, land-management practices, and infrastructure will be assessed by BLM to best protect Monument resources. The U.S.

Geological Survey, in cooperation with the BLM, conducted a study to assess the soil and water resources within the Monument to provide an inventory and compilation of naturalresource information needed by resource managers for the BLM's land-use planning process for this new national monument. The overall objectives of this study were to (1) compile and interpret existing soil- and water-resource data for the Monument and (2) provide a basic assessment of the surface hydrological effects of selected alternatives to current land use and infrastructure. Data were compiled by using geographic information system software and evaluated for hydrologic and landscape properties that influence infiltration, runoff, and erosion. The effects of changing vegetation were simulated by using different scenarios in the Rangeland Hydrology and Erosion Model. Results of this model indicate areas where soil loss or runoff may occur.

\section{Introduction}

The U.S. Geological Survey (USGS), in cooperation with the Bureau of Land Management (BLM), conducted a study to assess the soil and water resources within the Organ
Mountains-Desert Peaks National Monument (Monument) in southern New Mexico (fig. 1). Established in 2014, the Monument includes 775 square miles ( $\mathrm{mi}^{2}$; 496,330 acres) of BLM-administered land (fig. 2) within Doña Ana and Luna Counties and encompasses five mountain ranges: Organ, Doña Ana, Sierra de las Uvas, Robledo, and Potrillo Mountains (fig. 1) (BLM, 2018a). These mountain ranges are grouped into four Monument subunits that are administered as a single unit of the BLM's National Conservation Lands system (BLM, 2018a). The four subunits are the Organ Mountains, the Doña Ana Mountains, the Desert Peaks (includes the Sierra de las Uvas and Robledo Mountains), and the Potrillo Mountains (includes the East and West Potrillo Mountains) (BLM, 2018a) (fig. 1).

The charge of the BLM related to the Monument is to protect significant prehistoric, historic, geologic, and biologic resources of scientific interest within the Monument (BLM, 2018a). In desert landscapes, soil erosion is a concern and is related to soil type, geology, monsoonal moisture, or infrastructure. Vegetation and local topography are known to affect overland flow (Bergkamp, 1998), and rainfall intensity and runoff can affect the rate of infiltration into soil (Dunne and others, 1991). Low permeability soils, either naturally occurring or resulting from overgrazing or installation of infrastructure such as roads or pipelines, can decrease infiltration potential and increase runoff. An inventory and a compilation of natural-resource information are essential to provide information needed by resource managers for the BLM's land-use planning process for this new national monument. Of most immediate concern to the BLM are the current and potential future hydrologic characteristics of the Monument's landscape, including the effects of soil types, vegetative cover, location and quantity of livestock grazing, road locations, pipeline locations, and other potential development features on infiltration, runoff, and erosion.

The overall objectives of this study were to (1) compile and interpret existing soil- and water-resource data within the Monument and (2) provide a basic assessment of the potential surface hydrological effects of selected alternatives to current land use and infrastructure. The effects of changing vegetation 


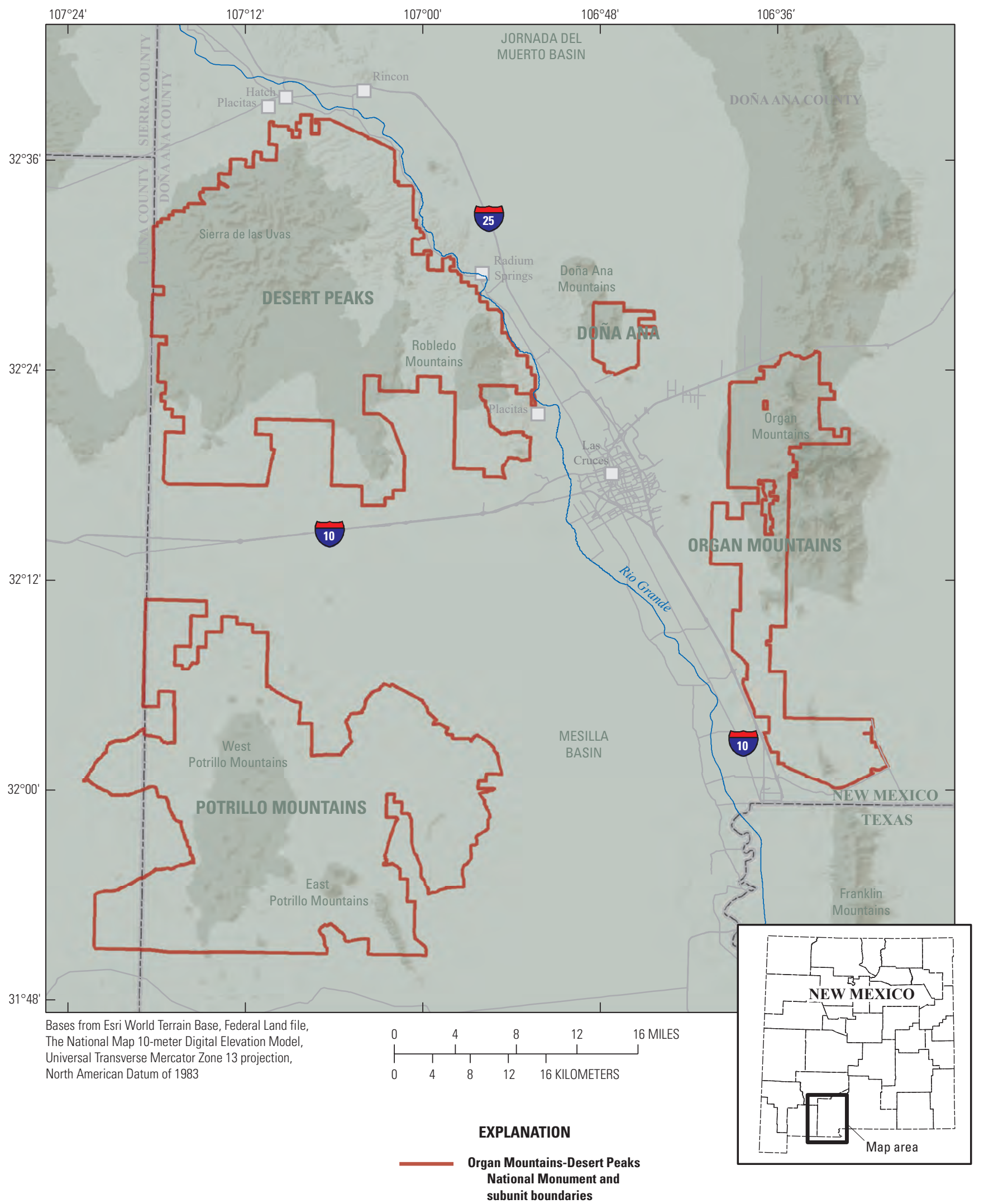

Figure 1. Location of the Organ Mountains-Desert Peaks National Monument subunits, New Mexico. 


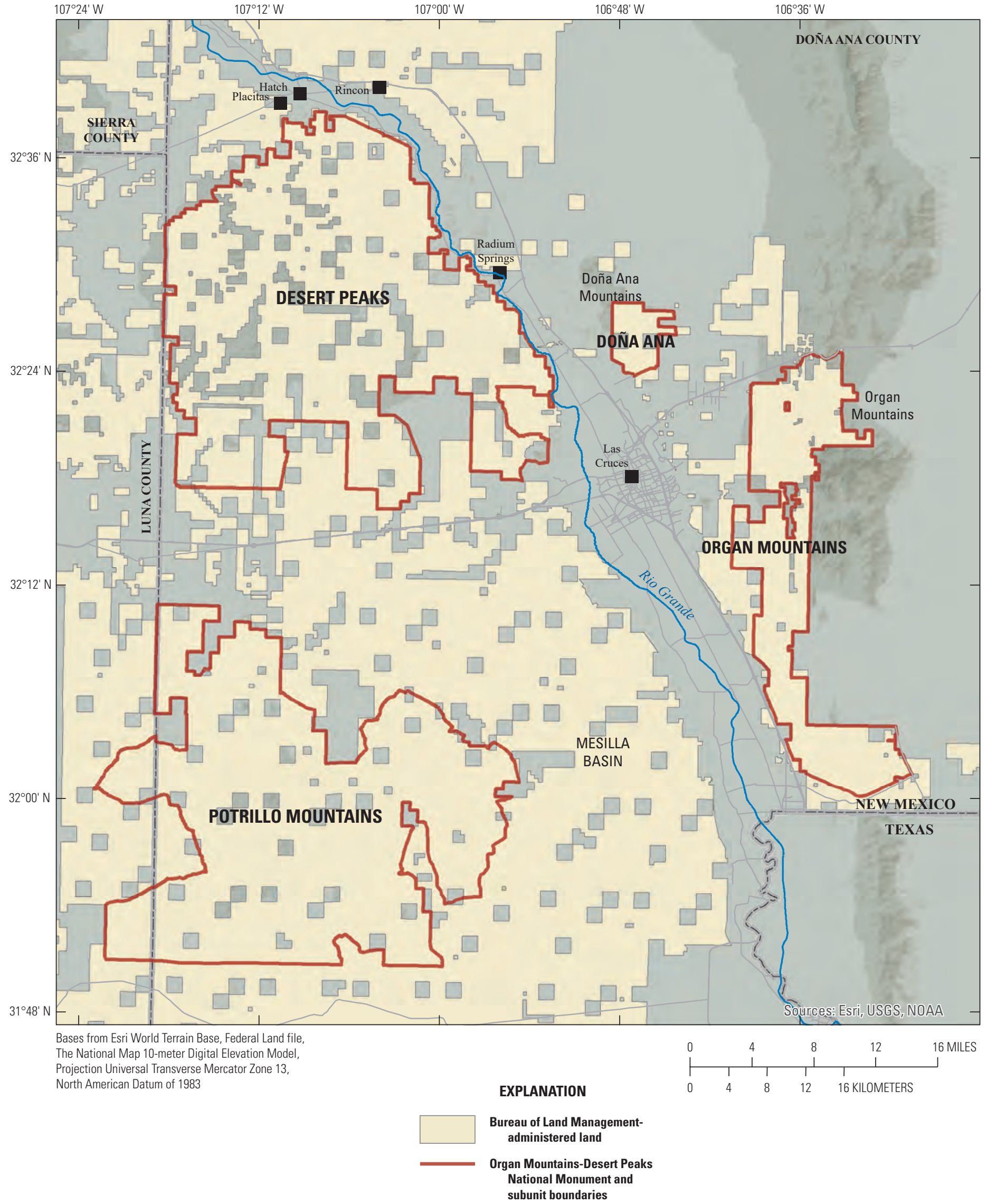

Figure 2. Land administered by the Bureau of Land Management (BLM) within and surrounding the Organ Mountains-Desert Peaks National Monument, New Mexico. 
were simulated by using different scenarios in the Rangeland Hydrology and Erosion Model (RHEM; Nearing and others, 2011) with the objective to develop and demonstrate a method to apply plot-scale vegetation and ground cover data to a broader landscape. This provides an understanding of different scenarios of vegetation and ground cover and how each scenario affects infiltration and runoff.

\section{Background}

The Monument is deemed important for its beautiful landscape and scientific, historic, and prehistoric resources (The White House Office of the Press Secretary, 2014). The mountain ranges within the Monument contain diverse geological and ecological resources. Future BLM resource management planning in the Monument needs to include consideration of a range of priorities, such as optimizing the functioning of the Chihuahuan Desert Ecosystem, as described in the 2014 Presidential Proclamation that designated the Monument. The BLM may authorize activities in the Monument in a manner that protects Monument objects and values. Given anticipated future demands in the Monument for recreation, livestock grazing, and maintenance of rights-of-way (for example, pipelines and powerlines), the BLM needs a better understanding of the current soil and water resources, as well as the potential effects that current infrastructure improvements may have on the watershed. Specifically, the BLM is concerned with infiltration and erosion and their relation to existing or planned infrastructure, such as roads, campgrounds, livestock grazing, and rights-of-way. Alternatives to the current land-use conditions, land-management practices, and infrastructure will be assessed by the BLM to best protect Monument resources.

The effects of grazing animals on the environment are largely influenced by the natural landscape condition, defined by characteristics such as land slope, soil type, and vegetation type, and the distribution of cattle on the landscape, controlled by factors such as stocking rate, access to water, and vegetation density around the water sources. Most cattle and horses will not graze on steeper slopes, instead choosing to graze in valleys and low-grade slopes (Undersander and others, 2002) from 0 to 3 percent (Emenkie and others, 2016). Grazing animals, specifically cattle, will travel about 800 feet (ft) to a quarter of a mile from their water source (Undersander and others, 2002). This concentrates foot traffic and compaction to areas near water sources and can lead to localized areas of overgrazing and poor vegetation cover. In some cases, the addition of organic material through livestock manure can build up soil organic matter, which could increase waterholding capacity and water-infiltration rates (Hubbard and others, 2004). Infiltration can be affected by vegetation type and density, coupled with grazing length and stocking rate in a particular allotment (McCalla and others, 1984). Blackburn (1983) presented the difference in sediment load and runoff related to type of grass, which can be altered depending upon grazing practices and therefore can directly affect hydrologic and soil processes on rangelands in the Monument. Poorly maintained livestock grazing areas can lead to reduced infiltration, accelerated runoff, and soil erosion (Sharma, 1997), with the most substantial grazing effects occurring near water sources.

The addition of new roads or increased maintenance on rights-of-way may result in decreased infiltration and increased runoff because of the reduction of permeable soil. Dirt roads can become compacted and have low infiltration potential, and paved roads typically have very low to no permeability.

\section{Purpose and Scope}

The purpose of this report is to describe an assessment of soil and water resources in the Monument. Specifically, this report describes the methods used for data compilation and model simulations; provides the results of data compilation, map development, model simulations, and data interpretation; and describes data gaps. Data were compiled and organized in geographic information system (GIS) software and used in creating landform maps and geology and weathering potential maps; evaluating watershed condition indicators; and providing input for the RHEM.

The maps developed from the compiled data show the locations where specific landforms exist, which rock types are likely to have chemical or physical weathering, how changes in vegetation may affect soil loss or runoff, and the infiltration potential across the Monument. The results of this study will help inform BLM decisions regarding Monument management alternatives that are within the scope of the National Environmental Policy Act environmental impact statement for land-use planning (BLM, 2019).

\section{Study Area Description and Background}

The Monument is within Doña Ana and Luna Counties in southern New Mexico (figs. 1, 2) and consists of four subunits: the Organ Mountains, Desert Peaks, Potrillo Mountains, and Doña Ana Mountains. The Desert Peaks subunit includes the Sierra de las Uvas and Robledo Mountains (BLM, 2018a).

\section{Climate}

The Foreign Agricultural Service of the U.S. Department of Agriculture reports precipitation in the Monument area ranging from 8 to 17 inches per year (in/yr; 203 to 432 millimeters per year $[\mathrm{mm} / \mathrm{yr}]$ ), depending on location (Glover, 1975; Morino, 1996; Malm, 2003). Annual climate normal data (1981-2010) for the State University gage (station 298535; Arguez and others, 2012) in Las Cruces, New Mexico, 
is $9.7 \mathrm{in} / \mathrm{yr}(247 \mathrm{~mm} / \mathrm{yr})$ rainfall, $2.6 \mathrm{in} / \mathrm{yr}(66 \mathrm{~mm} / \mathrm{yr})$ snowfall, and 62.4 degrees Fahrenheit ${ }^{\circ} \mathrm{F}\left(16.9\right.$ degrees Celsius $\left.\left[{ }^{\circ} \mathrm{C}\right]\right)$ average temperature (Arguez and others, 2012). Seasonal climate normal data indicate that 45 percent of annual precipitation falls from June to August during the summer monsoon, with moisture originating in the Gulf of Mexico (Terracon and others, 2003). Monthly normal (1981-2010) average temperatures range from $43.5^{\circ} \mathrm{F}\left(6.4^{\circ} \mathrm{C}\right)$ in December to $81.3^{\circ} \mathrm{F}$ $\left(27.4^{\circ} \mathrm{C}\right)$ in July (Arguez and others, 2012).

The 2015 annual total precipitation at the Chihuahuan Desert Observatory weather station (station ID: 294426) was above average (12.6 inches [in.]) with a weak monsoon (4.8 in., 38 percent of total annual precipitation), whereas 2016 was below average ( $8.4 \mathrm{in}$.) with a stronger monsoon (5.2 in., 61 percent of total annual precipitation) (National Oceanic and Atmospheric Administration [NOAA], 2018). Despite precipitation totals being below average in 2016, the monsoonal total was greater than one-half of the total annual precipitation, resulting in an overall average monsoon season.

\section{Vegetation}

Vegetation in the Monument region is influenced by factors including soil type, climate, topography, and natural and anthropogenic disturbances. The Monument consists primarily of eight vegetation macrogroups classified according to the U.S. National Vegetation Classification (USNVC) standards (USNVC, 2017) (table 1; fig. 3). Chihuahuan semi-desert grassland (M087) covers the most land area $\left(339.3 \mathrm{mi}^{2}\right)$ in the Monument. Warm and cool desert riparian woodland, madrean montane forest and woodland, and warm semi-desert cliff, scree and rock vegetation (M036, M011, and M117, respectively) cover the least area $\left(5.9 \mathrm{mi}^{2}\right)$. Most of the Monument is covered by at least $40-80$ percent vegetation (fig. 4), with parts of the Potrillo Mountains and Desert Peaks subunits having only 0-20 percent vegetation (Gaines and others, 2013).

Plant primary production in the Chihuahuan Desert is influenced primarily by current-year precipitation and secondarily by preceding-year precipitation. December through September precipitation has the highest correlation with perennial grass production (Khumalo and Holechek, 2005). The annual average precipitation varies widely in the Chihuahuan Desert, with more years of below average precipitation than above average precipitation (Khumalo and Holechek, 2005). During years of drought, the average decline of nonwoody species biomass (bunch grass, sod grass, and forbs) can be greater than 40 percent (Khumalo and Holechek, 2005). Additionally, most of the Monument is either presently grazed or is part of a grazing lease and may have increased grazing during part of the year (Vincent, 2017). Increased foot traffic from recreational visits is likewise expected to trample and reduce nonwoody species over woody shrubs or cacti. Furthermore, shrub encroachment has been documented across the Chihuahuan Desert, even in areas receiving anti-shrub treatments and management strategies to minimize their spread (Gibbens and others, 1988, 2005; Holechek and others, 1994).

Table 1. Vegetation macrogroups and common species within the Organ Mountains-Desert Peaks National Monument, New Mexico, and the area covered by each macrogroup (U.S. National Vegetation Classification, 2017).

\begin{tabular}{llr}
\hline \multicolumn{1}{c}{ Macrogroup } & \multicolumn{1}{c}{ Common species } & $\begin{array}{c}\text { Area, in } \\
\text { square } \\
\text { miles }\end{array}$ \\
\hline (M010) Madrean Lowland Evergreen Woodland & Mid-elevation pinyon, juniper, oak & 7.8 \\
(M011) Madrean Montane Forest and Woodland & Mid- to upper-elevation pine, Douglas fir, silverleaf oak & 0.7 \\
(M036) Warm and Cool Desert Riparian Woodland & Sweet acacia, boxelder, ash, cottonwood, willow, oak & 0.1 \\
(M086) Chihuahuan Desert Scrub & Creosote bush, American tarwort, mesquite & 266.3 \\
(M087) Chihuahuan Semi-Desert Grassland & Black grama, bullgrass, tobosagrass & 339.3 \\
(M092) North American Warm-Desert Xeric-Riparian Scrub & Buckwheat, beardtongue, bulb panicgrass, common wolfstail & 54.2 \\
(M117) Warm Semi-Desert Cliff, Scree \& Rock Vegetation & Sparsely vegetated areas with multiple species & 5.2 \\
(M512) North American Warm Desert & Honey mesquite, red brome, Lehmann's lovegrass & 203.9 \\
\hline
\end{tabular}




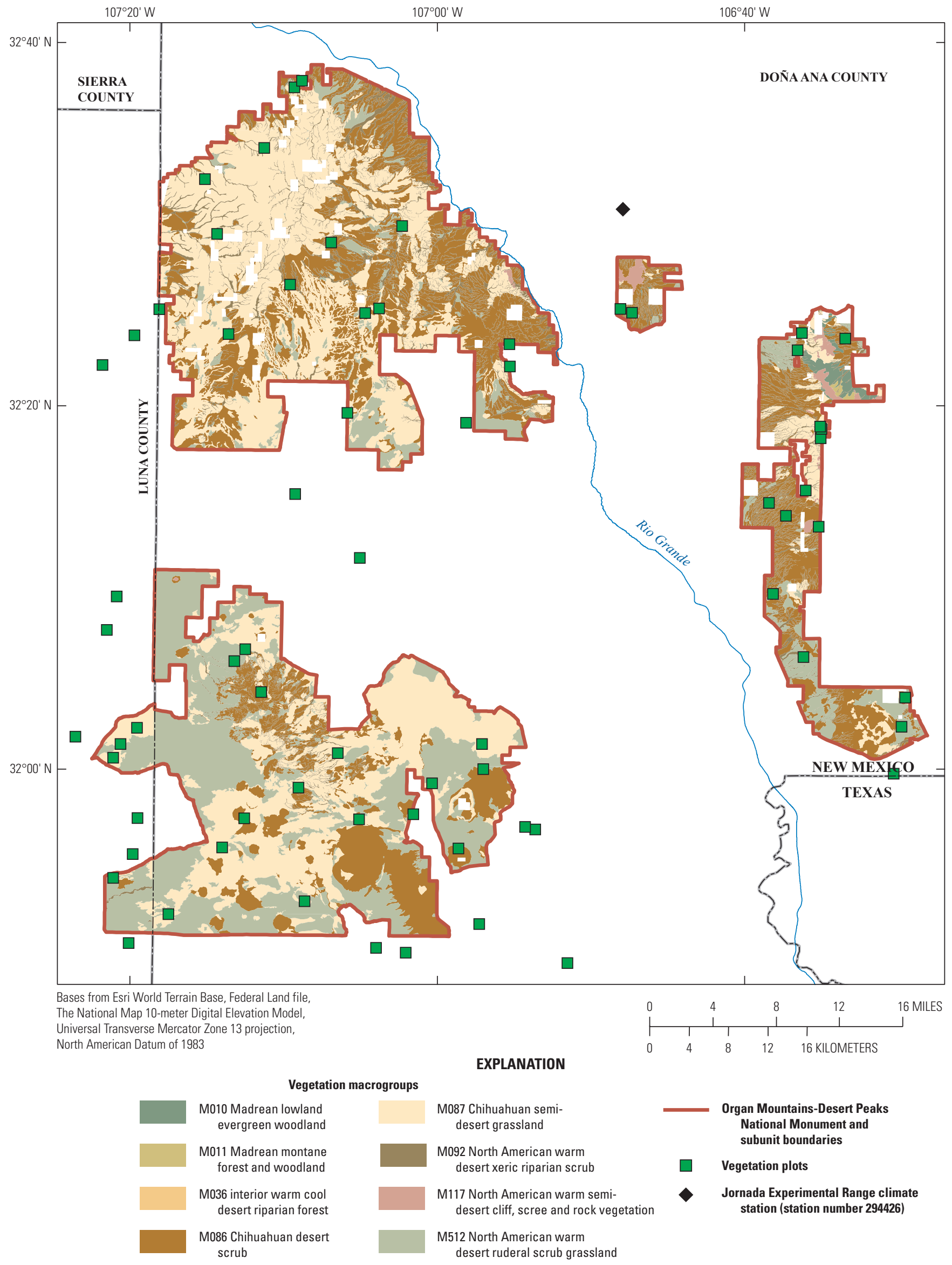

Figure 3. Vegetation macrogroups in the Organ Mountains-Desert Peaks National Monument, New Mexico (U.S. National Vegetation Classification, 2017). 


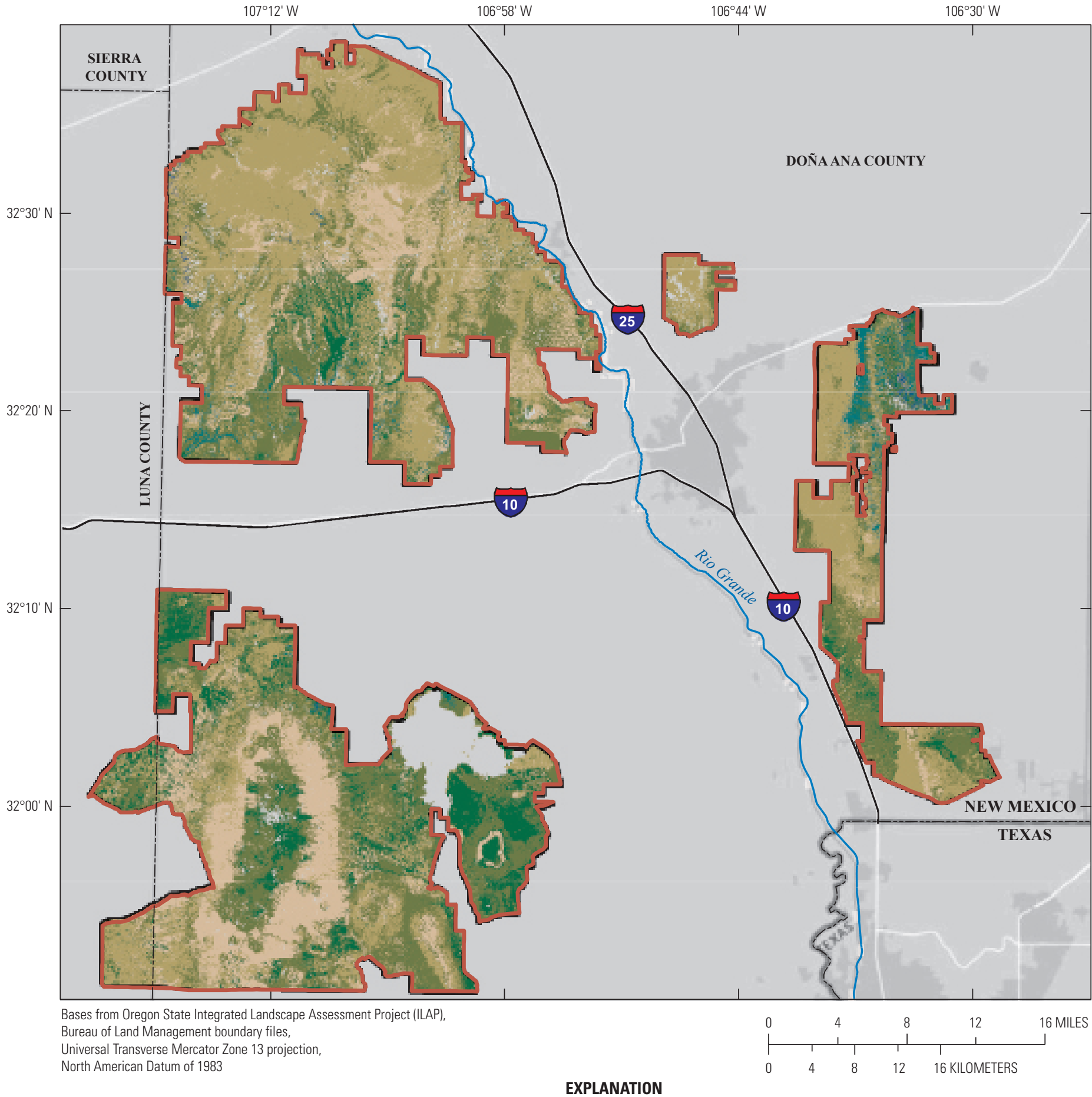

EXPLANATION

\begin{tabular}{l} 
Total percentage of vegetation cover \\
(grasses, shrubs, and trees) \\
\begin{tabular}{|l|l|}
\hline $0-20$ & $60-80$ \\
\hline $20-40$ & $80-100$ \\
$40-60$ & $\square$ \\
\hline
\end{tabular} \\
\hline
\end{tabular}

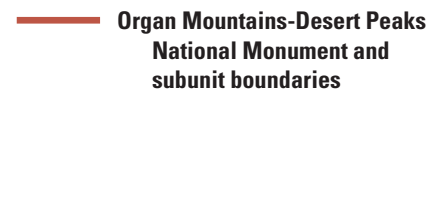

Figure 4. Total percentage of vegetation cover (2013) within and surrounding the Organ Mountains-Desert Peaks National Monument, New Mexico (Gaines and others, 2013). 


\section{Soils}

The U.S. Department of Agriculture (USDA), Natural Resources Conservation Service (NRCS; 2018) Gridded Soil Survey Geographic Database (gSSURGO) and U.S. General Soil Map (STATSGO2) datasets (NRCS, 2017a, b) were used to classify soils in the Monument (table 2; fig. 5). The soil texture classification is based on the proportions of sand, silt, and clay. Soils with texture modifiers, such as very gravelly or very cobbly, were grouped with soils in the associated texture class.

Sandy loam and silt loam soils occur most commonly in the Monument, covering more than 70 percent of the total Monument area (table 2). Loamy sand accounts for 20.7 percent of the soil texture in the Monument, and clay loam, sandy clay loam, silty clay loam, loam, and fine sand collectively cover 8.1 percent of the Monument. Soils influence the types of vegetation that grow in an area, as well as infiltration and erosion (Sampaio de Almeida and others, 2018). Typically, sandy soils have high infiltration rates, and soils consisting of finer particles (silt and clay) have lower infiltration rates, though many factors may affect this general rule (Hajiaghaei and others, 2014).

\section{Available Water Capacity}

Available water capacity in the Monument (fig. 6) refers to the amount of water a soil can store, expressed as depth in inches or centimeters that is then available for plant use (NRCS, 1998, 2017a). This parameter can be affected by soil properties, including rock fragments, organic matter, bulk density (which includes pore space), osmotic pressure (the amount of salt in the soil), and texture (NRCS, 1998). In general, the available water capacity in the Monument is low to moderate, $0-2.2$ in. (0-5.6 centimeters [cm]) (low) to $2.2-4.4$ in. $(5.6-11 \mathrm{~cm})$ (moderate) in the $0-59$ in. $(0-150 \mathrm{~cm})$ depth of soil. This information can be useful for understanding where vegetation occurs and can be combined with many of the maps presented in this report to help with understanding erosion, geomorphic changes near grazing locations, and potential for soil loss.

\section{Evapotranspiration}

Evapotranspiration (ET) is evaporation from soil, water, and vegetation surfaces combined with evaporation of water that is transpired by plants (USGS, 2019). ET can play a major role in the water balance of a watershed by affecting the water available for infiltration and runoff. Within the Monument, actual ET for 2015 ranged from 0 to 63.39 in. (0 to 1,610 millimeters [mm]) for individual 100meter (m) grid cells (Senay and others, 2016) (fig. 7). Low ET rates were at the lower elevations of the Monument, whereas the highest ET rates were at higher elevations, ranging from 5,249 to $8,858 \mathrm{ft}$ (1,600 to 2,700 m) above the North American Vertical Datum of 1988 (NAVD 88) (Mitchell and others,
2019). Although the central Potrillo Mountain subunit is within the elevation range for high ET, little to no ET occurred in this region in 2015 (Senay and others, 2016), possibly because of shallow soils and little water availability within that area. Higher ET is generally observed in forested watersheds (Zhang and Garbrecht, 2003) such as the Organ Mountains.

It is important to note that 2015 was a wetter year for New Mexico in comparison to the 2014 drought year (Senay and others, 2016). Therefore, the ET values displayed on figure 7 might be higher than normal, and if 2014 ET values were available, they may have been lower than normal.

\section{Structure and Surface Geology}

The rock types and their structure in the Monument can affect the weathering potential of rocks, infiltration of water to the subsurface, overland flow, and erosion. The Organ Mountains are a steep and jagged mountain range located east of the city of Las Cruces, New Mexico (fig. 1) (Glover, 1975). These mountains are composed of volcanic intrusions of Tertiary age, gravels and alluvium of Tertiary-Quaternary age, sedimentary rocks of Paleozoic age, and granites of Precambrian age. The dominant rock type is quartz-monzonite intrusions, especially on the western slopes (Glover, 1975). Figure 8 shows geologic maps from Seager and others $(1982,1987)$ and Seager $(1995)$

Table 2. Soil texture classes, area covered by each texture class, and percentage of total monument area covered by each texture class in the Organ Mountains-Desert Peaks National Monument, New Mexico, according to the Natural Resources Conservation Service (2017a) soil survey.

\begin{tabular}{lcc}
\hline \multicolumn{1}{c}{ Soil texture } & $\begin{array}{c}\text { Soil texture } \\
\text { area covered, } \\
\text { in square miles }\end{array}$ & $\begin{array}{c}\text { Percentage } \\
\text { of total } \\
\text { monument } \\
\text { area }\end{array}$ \\
\hline Clay & 0.0 & 0.0 \\
\hline Clay loam & 19.7 & 2.2 \\
Very cobbly clay loam & 7.7 & 0.9 \\
\hline Sandy clay loam & 6.6 & 0.7 \\
\hline Silty clay loam & 223.3 & 24.9 \\
\hline Silt loam & 27.6 & 3.1 \\
\hline Loam & 11.1 & 1.2 \\
\hline Sand & 408.1 & 45.5 \\
\hline Sandy loam & & \\
Very gravelly fine sandy loam & & \\
Very gravelly sandy loam & & \\
Fine sandy loam & & \\
Gravelly fine sandy loam & & \\
\hline Loamy sand & & \\
Loamy fine sand & & \\
Loamy very fine sand & & \\
\hline
\end{tabular}




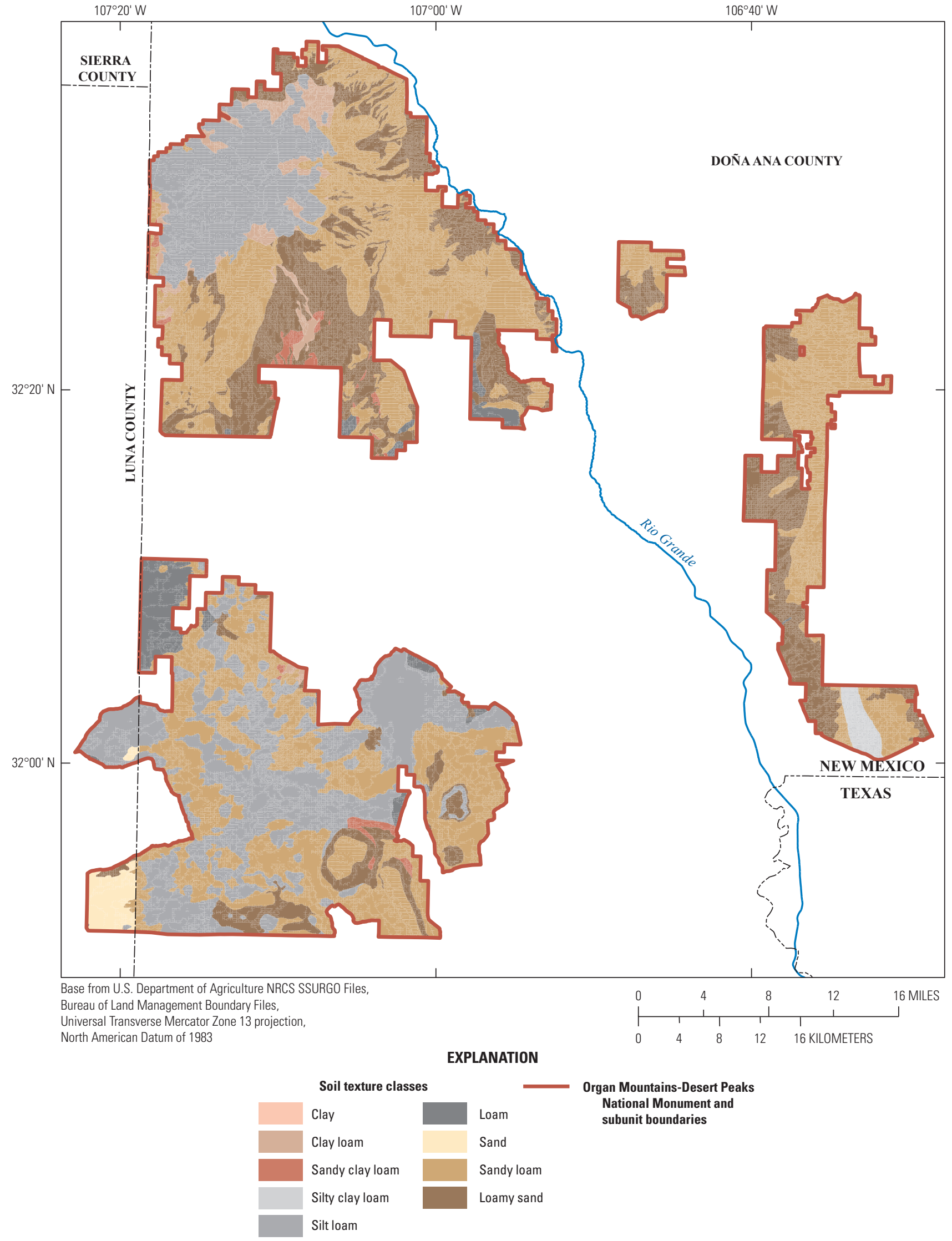

Figure 5. Soil texture classes in the Organ Mountains-Desert Peaks National Monument, New Mexico, according to the Natural Resources Conservation Service (2017a) soil survey. 

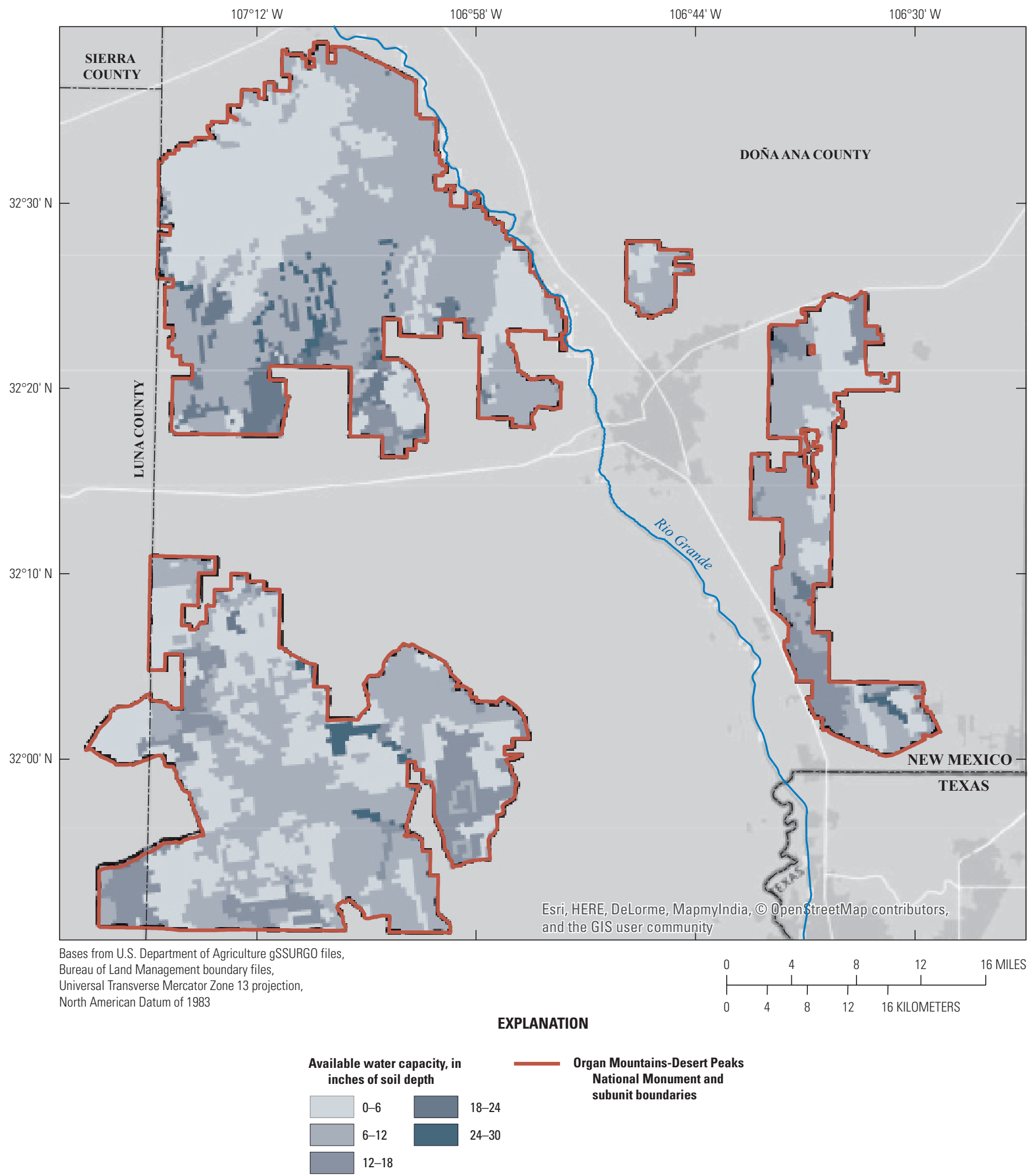

Figure 6. Available water capacity of soils in the Organ Mountains-Desert Peaks National Monument, New Mexico (Natural Resources Conservation Service, 2017a). 




Evapotranspiration data does not extend past Doña Ana County.

Figure 7. Average evapotranspiration rates for 2015, Organ Mountains-Desert Peaks National Monument, New Mexico (modified from Senay and others, 2016). 


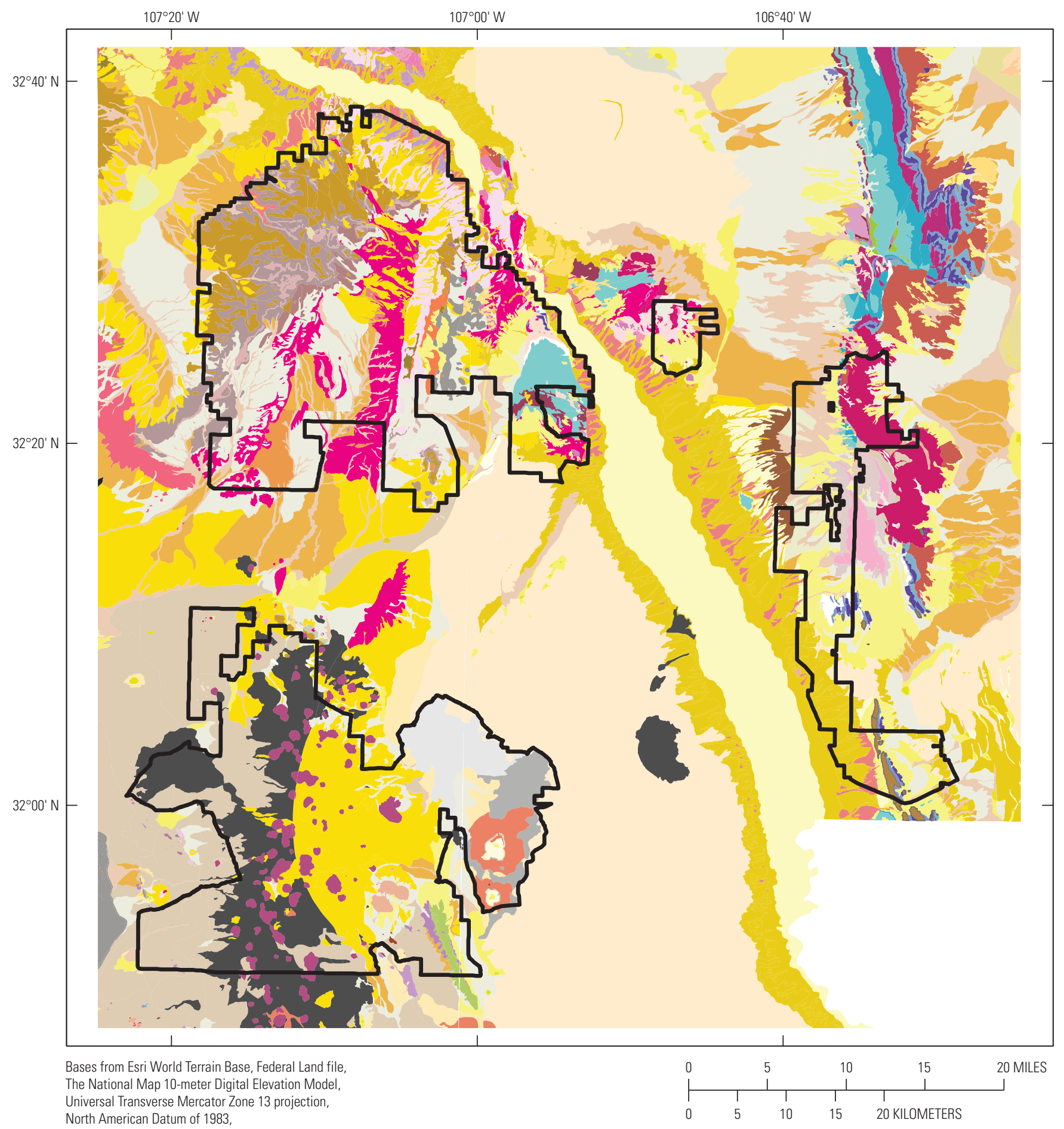

North American Datum of 1983

Seager, 1995; Seager and others, 1982, 1987

Figure 8. Geology of the area within and surrounding the Organ Mountains-Desert Peaks National Monument, New Mexico (Seager and others, 1982, 1987; Seager, 1995). 


\section{EXPLANATION}

Quaternary

Fluvial-facies

Fluvial-facies

Piedmont-slope facies

Arroyo-channel, fan, deposits

Fan and terrace deposits

Basin sediments

Camp Rice Formation transitional deposits

Lake Deposits

Alluvial deposits

Closed-basin deposits

Basin-floor deposits

Eolian sand dunes

Flood-plain and channel deposits

Playa deposit

Ancestral Rio Grande drainage

Quaternary (continued)
Modern drainageway deposits

Piedmont-slope facies

River, arroyo, fan deposits

Tuff and breccia

Basalt of West Potrillo Mountains

Olivine basalt

Afton Basalt

Aden Basalt

Tertiary

Tuffs and epiclastic rocks

Uvas Basaltic Andesite

Member of Uvas Basaltic Andesite

Silicic plutonic intrusions

Andesite-latite flows
Tertiary (continued)

Rubio Peak Formation

Palm Park Formation

Lower Cretaceous rocks

Permian

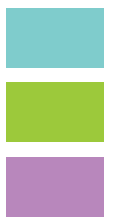

Hueco Limestone

Abo Formation

Yeso-San Andres Formations

Pennsylvanian

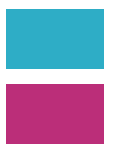

Panther Seep Formation

Lead Camp Limestone

Cambrian to Silurian

Dolomite

Precambrian granite

Organ Mountains-Desert Peaks National Monument and

subunit boundaries

Figure 8. Geology of the area within and surrounding the Organ Mountains-Desert Peaks National Monument, New Mexico (Seager and others, 1982, 1987; Seager, 1995).-Continued 
combined into one map. This new map is included in the data release (Mitchell and others, 2019) that is associated with this report and provides more detail than the statewide geologic map digitally available (Green and Jones, 1997).

In the Desert Peaks subunit, the geology is aphanitic volcanic rocks, andesite, pyroclastic lava flows, silicic intrusions, limestone, alluvium, and clastics that range in age from Permian to Quaternary (fig. 8). In the Potrillo Mountains subunit, the East and West Potrillo Mountains are part of the Quaternary-age Potrillo Volcanics, which contains olivine basalts (Kilburn and others, 1988; Hoffer, 2001). Approximately 125 individual cinder cone volcanoes have been identified within the West Potrillo Mountains. The East Potrillo Mountains consist of aphanitic and phaneritic volcanic rocks as well as alluvium, clastics, and sandstones (fig. 8). The Doña Ana Mountain range trends from the south-southeast to north-northwest. The mountains tilt westward, and the bedrock ranges in age from Permian to Quaternary (Seager and others, 1976). Two-thirds of the bedrock is volcanic in origin and includes monzonites, andesites, obsidian, and ash flow tuffs; the remaining rocks are of sedimentary origin (Seager and others, 1976) and include alluvium and clastic deposits (fig. 8).

The geology and potential for weathering of rocks in the Monument are important in understanding the overall potential for erosion and sediment availability in the Monument. For example, in locations with steeper slopes, weathered rock tends to erode and deposit at a lower elevation in the subunit, decreasing the potential for soils to form at higher elevations. This could affect infiltration and runoff.

\section{Weathering Potential}

Numerous factors affect weathering processes, including the minerals present and known mineral weathering rates (Goldich, 1938), chemical composition of rocks and sediments, slope, aspect, vegetative cover, biology, and average precipitation (Drever, 1994; Wilson, 2004; McFadden and others, 2005). The primary minerals in igneous rocks crystallize and weather in an order that is dependent on the mineral structure (Bowen, 1922; Goldich, 1938), which is helpful for understanding relative weathering rates. Mechanical (physical) and chemical weathering are affected by temperature and moisture, where low annual precipitation and extreme high annual temperatures create an environment with some physical weathering and very little chemical weathering (Bierman and Montgomery, 2014). Physical weathering occurs where rock is exposed on the ground or in outcrops (Selby, 1993). Physical weathering alone does not alter the chemistry of a rock but may make a rock more susceptible to chemical weathering with increased surface area or opening of a fracture.

Common physical processes are frost action, insolation (McFadden and others, 2005), salt or ice crystal growth, and internal rock stress (Selby, 1993). Weathering due to frost occurs when there is a phase change from liquid to solid, thus increasing the volume of the phase, and can open fissures or cracks in rocks. Insolation is the exposure to sun, which can affect physical weathering in deserts, especially during the hottest months (Eppes and others, 2010). Darker rocks retain more heat than lighter colored rocks, so basalt would be hotter than a limestone. Growing salt or ice crystals have the potential to exert enough pressure to crack the wall of a rock. In addition, salt weathering is common in desert areas because of evaporation of water; therefore, salt weathering could occur in any of the areas within the Monument. Internal rock stress can include fracture from a large rock sitting on top of a smaller rock, exposure to fire, which will induce thermal expansion, and stress from rock formation such as in igneous rocks (Selby, 1993).

Physical and chemical weathering rates influence one another, and vegetation plays an important role in weathering where roots can physically break down rock or secrete organic acids, which increase chemical breakdown. Because rain is an important factor in chemical weathering, chemical weathering is not as active a weathering process in arid settings as is physical weathering. However, using geochemical data to calculate chemical weathering indices is helpful for understanding areas of the Monument that are already weathered or have the potential to be weathered. Chemical weathering indices compare the depletion of mobile elements, or those that are more easily weathered and mobilized, to immobile elements present in a rock. Each weathering index has a slightly different equation for evaluating degree of weathering due to differences in which elements are considered mobile. By looking at five weathering indices (described in the Geologic and Weathering Potential section), the potential for weathering based upon different elements can be better understood.

\section{Groundwater Hydrology}

The Mesilla and the Jornada del Muerto Basins are the main surface basins covering the extent of the Monument (fig. 1). These two surface basins are predominantly located in the Lower Rio Grande groundwater basin. In New Mexico, the Office of the State Engineer defines a groundwater basin as "an area declared by the State Engineer to be underlain by a groundwater source with reasonably ascertainable boundaries" (New Mexico Office of the State Engineer/Interstate Stream Commission [NMOSE/ISC], 2018). The Mesilla Basin spans most of Doña Ana County from north to south and is delineated by the Organ Mountains on the east side, the East and West Potrillo Mountains to the southwest, and the Robledo and Doña Ana Mountains in the northwest (Hawley and others, 2001). The Mesilla Basin aquifer system is hydraulically connected to the Rio Grande and is mainly recharged by the river (Sheng, 2013; Teeple, 2017). Additional recharge occurs through infiltration from agricultural irrigation and mountain-front recharge infiltrating local arroyos (Sheng, 2013). The Mesilla Basin aquifer system, which is prominent in the area, is relied upon for irrigation and municipal and domestic supplies in the United States and Mexico (Teeple, 2017). 
The southern part of the Jornada del Muerto Basin extends into the northern part of Doña Ana County, between the Doña Ana and Organ Mountain chains, forming a transitional boundary with the Mesilla Basin. Moderate mountainfront recharge occurs in the southern part of the basin from the Doña Ana and Organ Mountains (Hawley and others, 2001). Groundwater flow in the southern portion of the Jornada del Muerto Basin is westward, towards the Mesilla Basin (Teeple, 2017).

Wells within and surrounding the Monument are generally screened in the Oligocene to Pliocene Santa Fe Formation, part of the Rio Grande aquifer system, which is within the Lower Rio Grande groundwater basin (USGS, 2018c). Nearly all groundwater wells in the Monument identified in the USGS Geographic Names Information System (GNIS) (USGS, 2018b) and National Water Information System (NWIS) Mapper (USGS, 2018c) databases are deemed inactive, which means that the depth to water in a well has not been measured in a year or more. The USGS and the NMOSE/ ISC collaborate to collect, store, and make measurements available in the NWIS database (NMOSE/ISC, 2018; USGS, 2018c). Some wells may have only been measured once, and some may be points of diversion for livestock water supply tanks. Additional groundwater wells that are not identified in the USGS NWIS database could be in the Monument.

Wells in the area include observation, and water wells, but within the Monument boundary, all are water wells (fig. 9). Only one or two unused wells are in the Monument according to the USGS GNIS and NWIS databases (USGS, 2018b, c). Other uses of wells in the vicinity include geothermal and test hole sites. Some wells may be unused or destroyed; however, evaluating the locations of these wells was beyond the scope of this study.

\section{Surface-Water Features}

Surface-water features identified in and around the Monument are shown in figure 10. Existing surface-water data provided by BLM (Mitchell and others, 2019) were cross referenced with features identified in the USGS GNIS (2018b) database and features described in the New Mexico Lower Rio Grande Water Plan (Terracon and others, 2003). Prominent arroyos include the Placitas Arroyo and Broad Canyon originating in the Desert Peaks subunit, and the Tortugas, Mossman, Alameda, and Las Cruces Arroyos originating in the Organ Mountains subunit (Terracon and others, 2003) (fig. 10). Conditions for arroyo formation include lack of vegetation, high rates of evaporation, and low precipitation rates. These three factors lead to a lack of moisture-retentive soil on many of the slopes in the Monument (Huggett, 2007). Dams that have been identified within the Monument are primarily located in the Desert Peaks and Organ Mountains subunits and are used for flood control (Terracon and others, 2003). Springs are mostly in and around the Organ Mountains subunit. Earthen impoundments in the Monument are a mixture of erosion dams or reservoirs and grazing water features that may or may not hold water based on the seasonality of each (Mitchell and others, 2019) (fig. 10). All canals that have been identified are located along the Rio Grande and are used primarily for agricultural irrigation (not shown on map). Additional data collection would need to be done to further distinguish between each type of surface-water feature.

\section{Current Infrastructure}

Numerous recreational areas, campgrounds, hiking trails, and roads currently exist within the Monument. There are approximately 380 recreational areas, including camping and picnic areas, and most are limited to the Desert Peaks and Organ Mountains subunits (Mitchell and others, 2019). The Desert Peaks and Doña Ana subunits have trails such as the Figure Eight/Cathedral trails and the Canyon Loop trail (fig. 11). According to BLM, recreational trails of note located in the Organ Mountains subunit include the Arroyo, Crawford, Dripping Springs, Filmore, and La Cueva trails (fig. 12). Other trails in the Organ Mountains subunit include the La Maria trails and the Pine Tree trails in the northern portion of the subunit. Many two-track and dirt roads traverse and intersect the Monument allowing for mountain biking, motorcycling, dirt bikes, hiking, and more (BLM, 2018a). The Potrillo Mountains subunit does not have maintained trails or other infrastructure. Each of these infrastructure components potentially affect infiltration, gullying caused by erosion, or overland flow in the region.

Roads can affect hydrology and geomorphology by altering surface runoff flow as well as the rate and location of erosion (Baird and others, 2012; Seutloali and Beckedahl, 2015). Surface erosion associated with roads, especially dirt or gravel roads, is primarily affected by overland flow (Baird and others, 2012). Infiltration-excess overland flow is caused by a variety of factors. The overland flow occurs when precipitation exceeds the infiltration capacity of the soil and has been observed on roads even during low-intensity precipitation events (Croke and others, 2005). Compacting road surfaces can decrease infiltration rates relative to the surrounding landscape (Spinelli and Marchi, 1996). The removal of vegetation during construction or from traffic pull-offs on road berms can also make surfaces adjacent to roads susceptible to decreased infiltration and increased erosion (Baird and others, 2012). Roads often transect hillslope hydrology and create a barrier that intercepts surface and subsurface flows and redirects them in new overland-flow or concentrated-flow pathways (Spinelli and Marchi, 1996; Seutloali and Beckedahl, 2015). Cut slopes, sections of a hill that are cut to allow for roads or rail lines, have large erosion rates from freeze-thaw processes and mass wasting due to their steep gradients and lack of vegetation (Arnáez and others, 2004).

Additional soil erosion near roads may be initiated as gullies within surface drainage structures that divert water from road surfaces (Seutloali and Beckedahl, 2015). Gullies increase the connectivity of runoff to stream channels. Runoff from roads that can disperse in nongullied pathways 


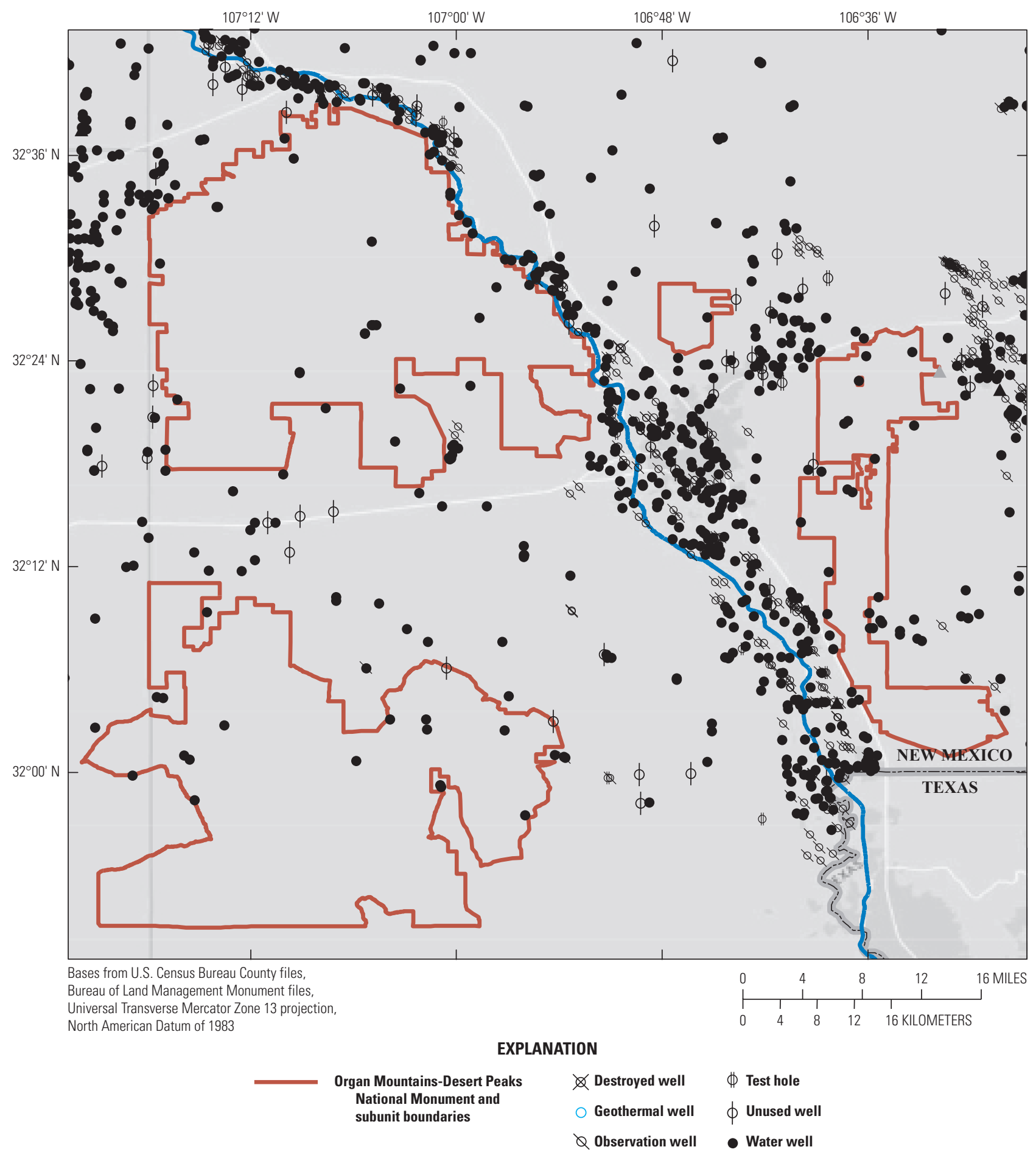

Figure 9. U.S. Geological Survey and New Mexico Office of the State Engineer wells and test holes near the Organ Mountains-Desert Peaks National Monument, New Mexico (U.S. Geological Survey, 2018b, c). 


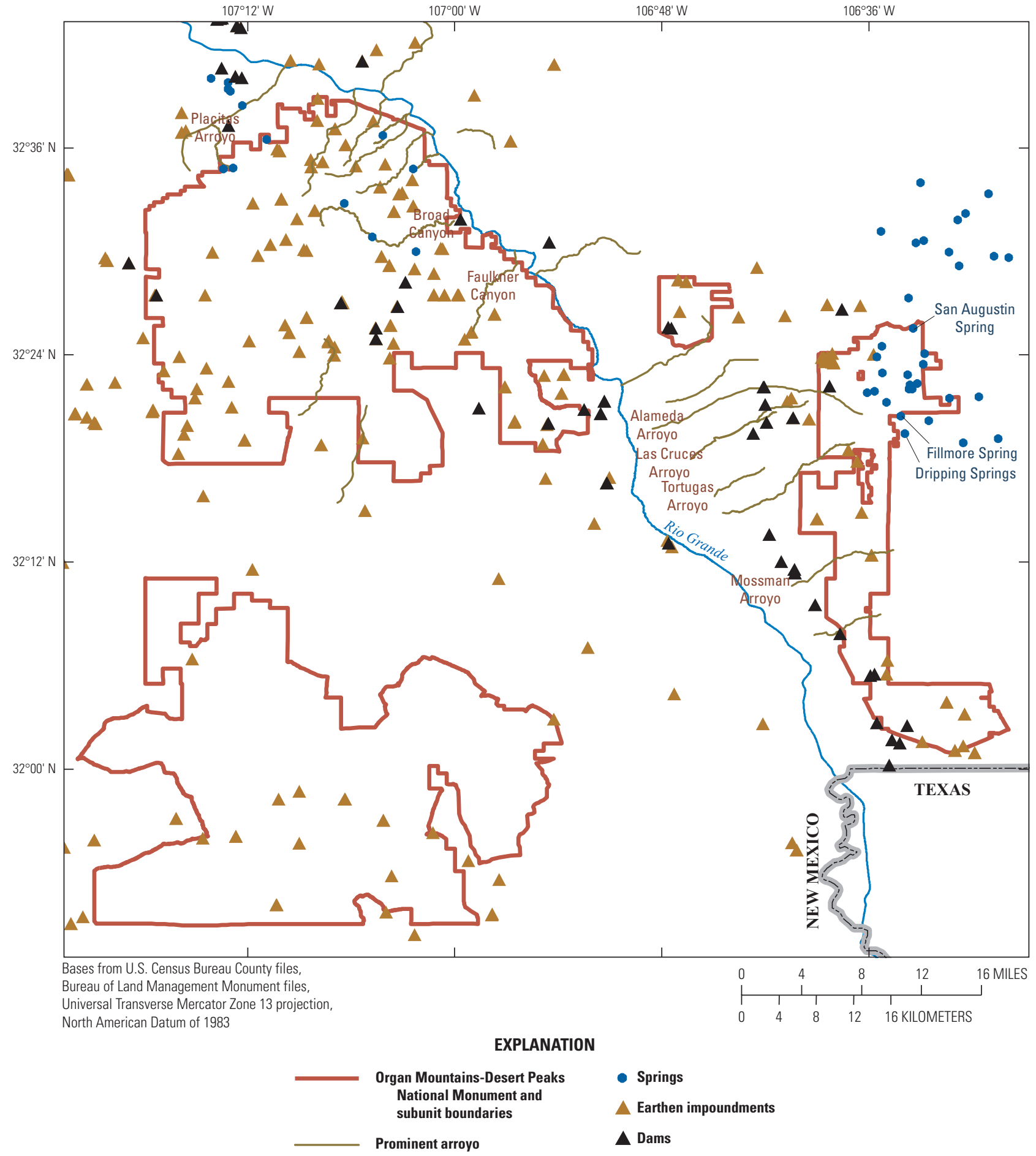

Figure 10. Locations of surface-water features in and near the Organ Mountains-Desert Peaks National Monument, New Mexico (U.S. Geological Survey, 2018b; Mitchell and others, 2019). 


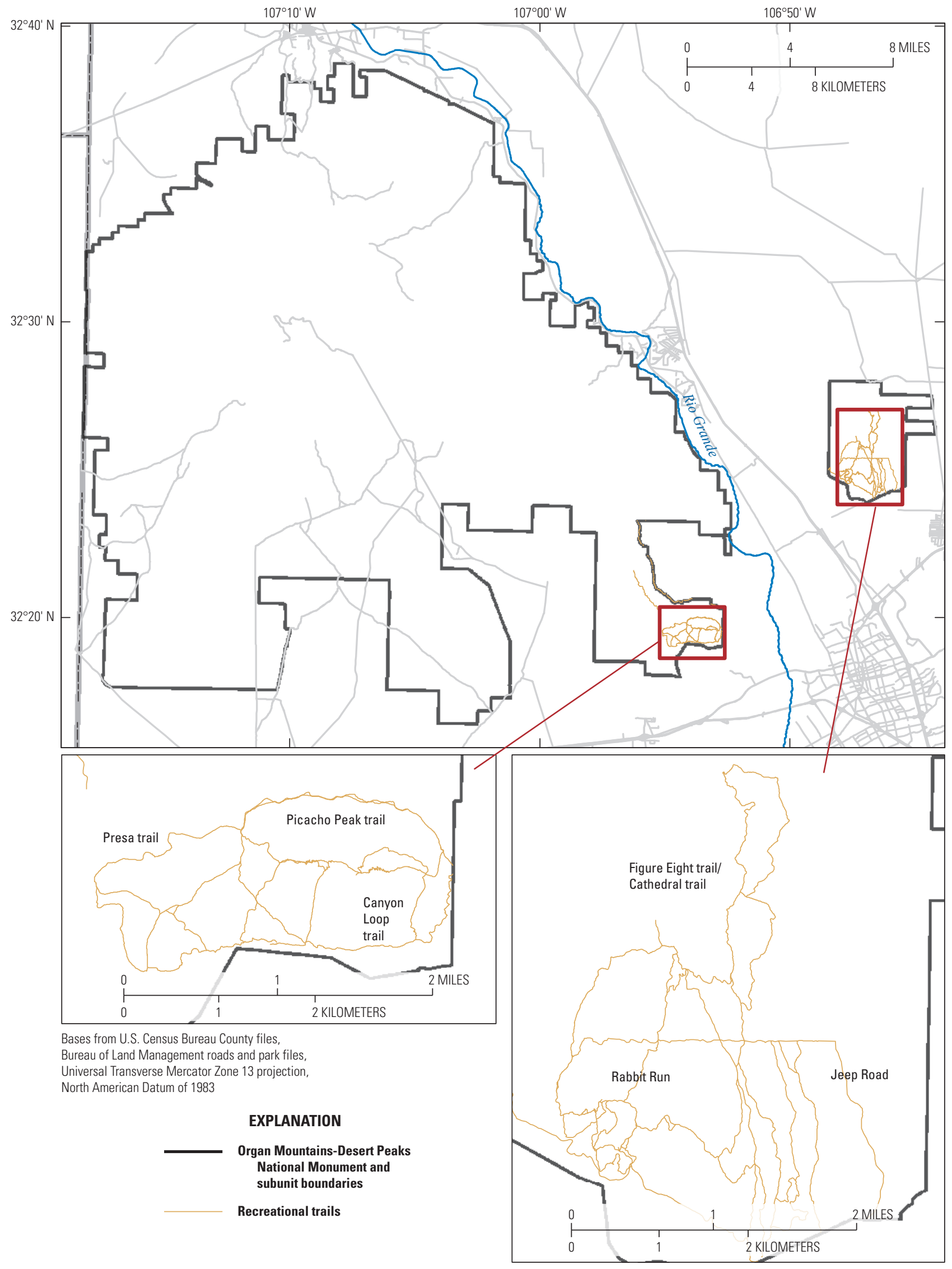

Figure 11. Recreational infrastructure for the Desert Peaks and Doña Ana subunits of the Organ Mountains-Desert Peaks National Monument, New Mexico (Mitchell and others, 2019). 


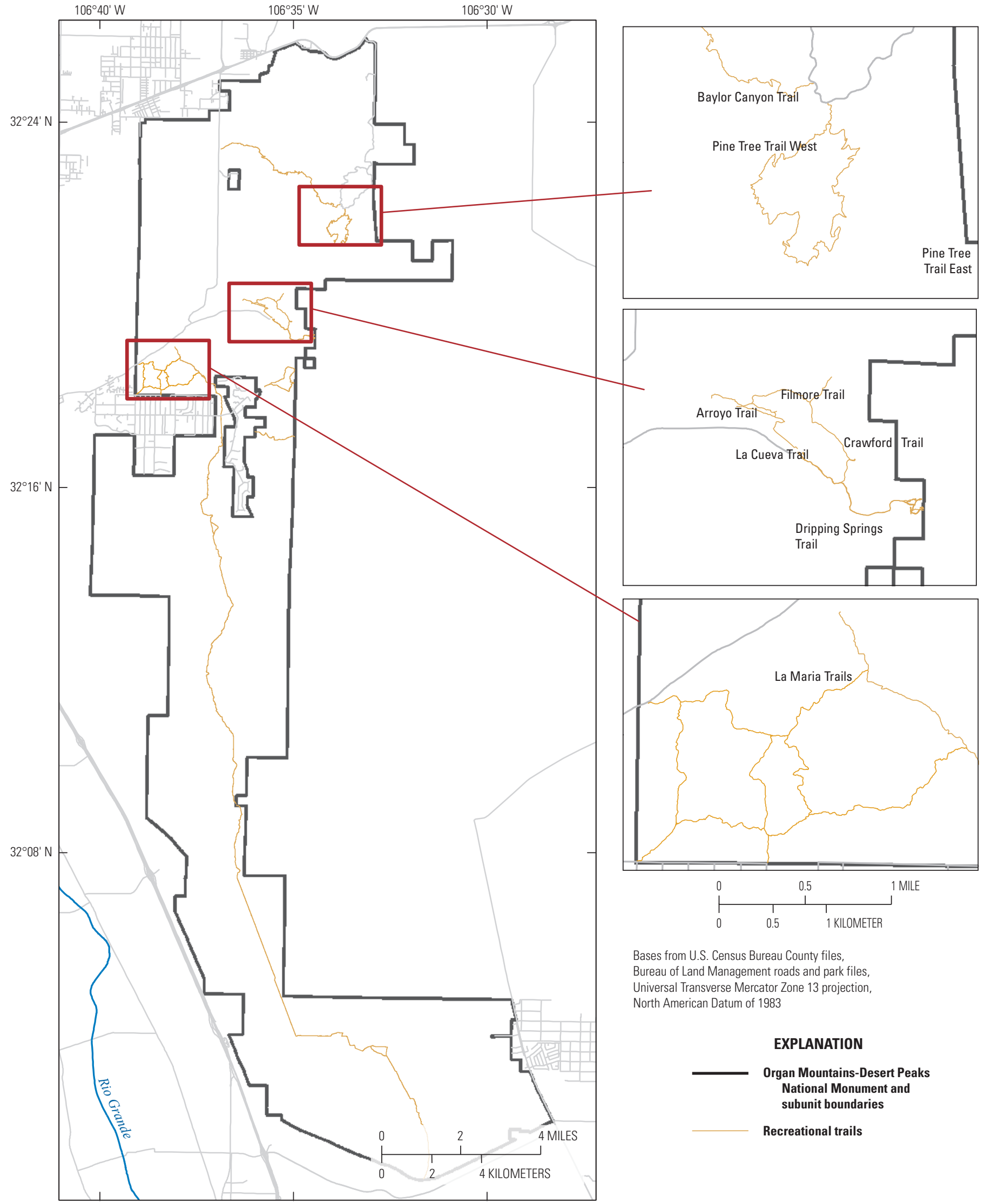

Figure 12. Recreational infrastructure for the Organ Mountains subunit of the Organ Mountains-Desert Peaks National Monument, New Mexico (Mitchell and others, 2019). 
has reduced connectivity and greater infiltration than runoff transported in gullied pathways created by drainage structures (Croke and others, 2005). Croke and others (2005) found that the average sediment transport distance below road outlets was $292 \mathrm{ft}(89 \mathrm{~m})$, which is similar to the results reported by Megahan and Ketcheson (1996). Roads within this distance to drainage channels can substantially contribute to sediment transport and sediment concentrations within streamflow. Also, longer road segments can yield higher amounts of sediment within basins (Baird and others, 2012).

\section{Livestock Grazing}

Livestock grazing data for the Monument have been previously unpublished by BLM and have been compiled into the data release that accompanies this report (Mitchell and others, 2019). The Monument, much like other BLM-administered land, is open to livestock grazing allotments (fig. 13). The Monument has 37 major grazing allotments, including about 9,500 cattle, horses, and sheep (Mitchell and others, 2019), numerous stock tanks, and fence lines separating different pastures, apart from a small area in the Organ Mountains subunit that is not being grazed. Ownership of the allotments includes BLM (86.6 percent), the State of New Mexico (11.7 percent), and privately held interests (1.7 percent), totaling 86,271 animal unit months (Mitchell and others, 2019), where the BLM defines an animal unit month for Federal grazing fee determination as "one cow and her calf, one horse, or five sheep or goats for a month" (BLM, 2018b). Grazing on the Monument will be maintained in all Monument subunits at pre- Monument-designation levels (Vincent, 2017).

A combination of distance to water, vegetation, soil infiltration and runoff, and slope can highly influence the potential for grazing and the effects that grazing can have on the environment. Erosion potential within a quarter-mile buffer zone around watering troughs increases because of the number of animals feeding in a small area (Undersander and others, 2002). Loss of vegetation from soil compaction related to livestock travel can lead to lower infiltration rates and increased runoff on slopes.

\section{Methods}

Several approaches can be used to assess the hydrologic characteristics of a landscape. In addition to the compilation of basic data, such as geology, well locations, soil classes, vegetation, and climate, the creation of digital landform maps and geologic weathering potential maps, development of watershed models, and assessment of watershed health indicators can aid in further understanding of the current landscape condition and potential vulnerability to change. Landforms are shaped by interactions among local geology, climate, hydrology, and vegetation. Landform processes can be sudden, such as mass wasting in response to a single storm, or can occur over time, such as the migration of dunes from exposure to constant wind (Dikau and others, 1991). Landforms may be classified by visual inspection of topographic maps, aerial photos, or lidar data or by field mapping, but can also be classified through computer methods by using digital elevation models (DEMs). A computer classification approach was used for this study because it is reproducible and can provide more detail to landform maps than can be achieved by visual creation alone. An analysis of landforms can provide information about the future paths of overland flow, locations of past and future erosion and deposition, and a sense of the timescales of past erosional processes. Watershed models and watershed health indicators provide tools that integrate basic geospatial data in ways that can inform management decisions.

Data of various types, sources, formats, and scales were compiled for use in this study. Data from publicly available sources are cited. Data from sources that are not publicly available were compiled into a geodatabase and published as a data release (Mitchell and others, 2019). All datasets, sources, and citations used in this study are listed in table 3 .

\section{Geologic and Weathering Potential}

Geochemical data for rocks sampled in the Monument at specific locations were obtained from EarthChem, a publicly accessible geochemical database (EarthChem, 2018). By using these geochemical data, weathering potential of individual samples were calculated by using five weathering indices. 


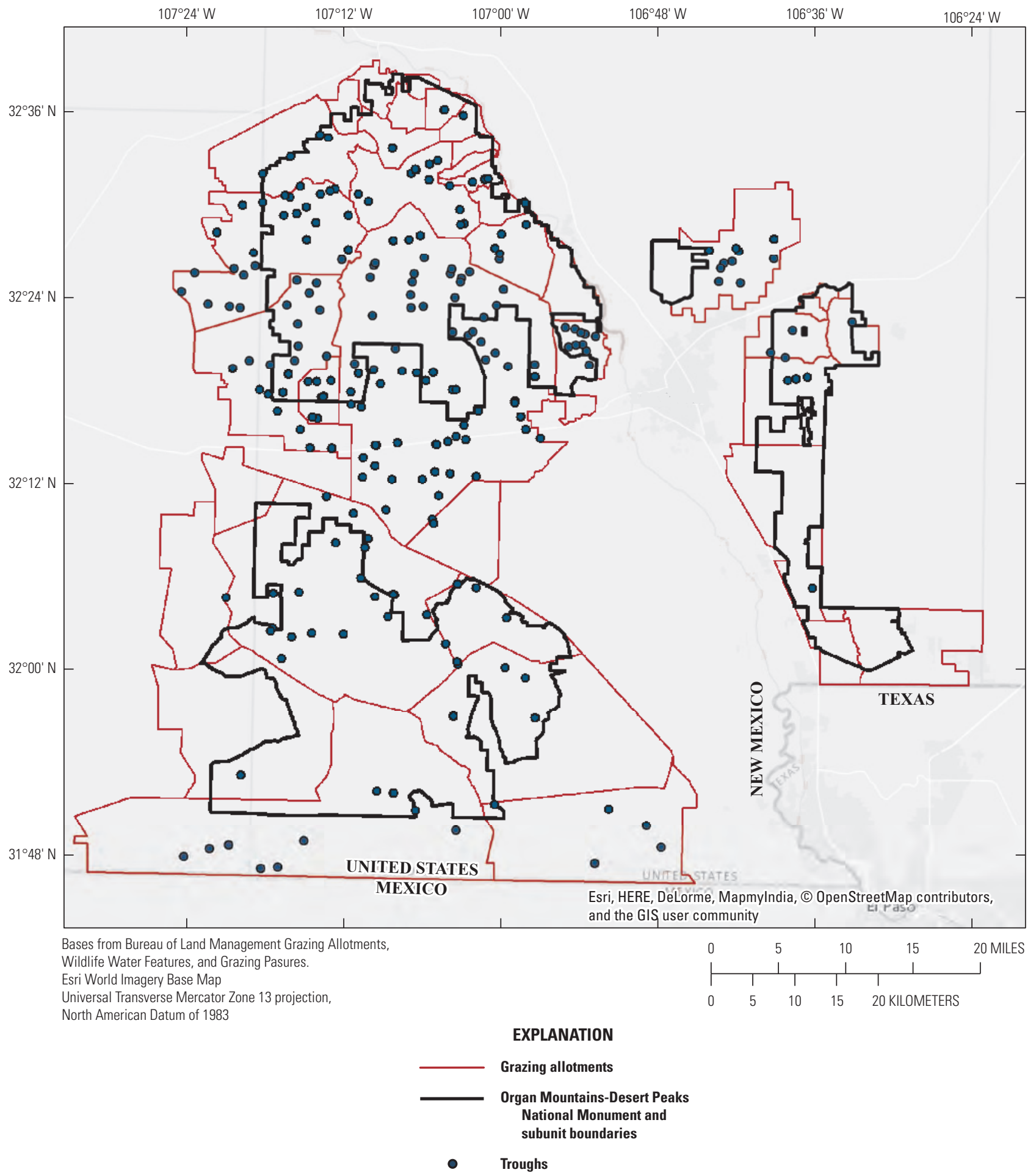

Figure 13. Locations of grazing allotments and troughs in the Organ Mountains-Desert Peaks National Monument, New Mexico (Mitchell and others, 2019). 


\section{Assessment of Soil and Water Resources in the Organ Mountains-Desert Peaks National Monument, New Mexico}

Table 3. Summary of data used in the assessment of soil and water resources in the Organ Mountains-Desert Peaks National Monument, New Mexico.

[TNM, The National Map; NASA, National Aeronautics and Space Administration; RHEM, Rangeland Hydrology and Erosion Model; USDA-ARS-SWRC, U.S. Department of Agriculture Southwest Watershed Research Center; NWIS, National Water Information System; GNIS, Geographic Names Information System; gSSURGO, Gridded Soil Survey Geographic database; BLM, Bureau of Land Management; NHD, National Hydrology Dataset; ILAP, Integrated Landscape Assessment Project; USGS, U.S. Geological Survey; NRCS, Natural Resources Conservation Service; STATSGO2, U.S. General Soil Map dataset; USNVC, U.S. National Vegetation Classification]

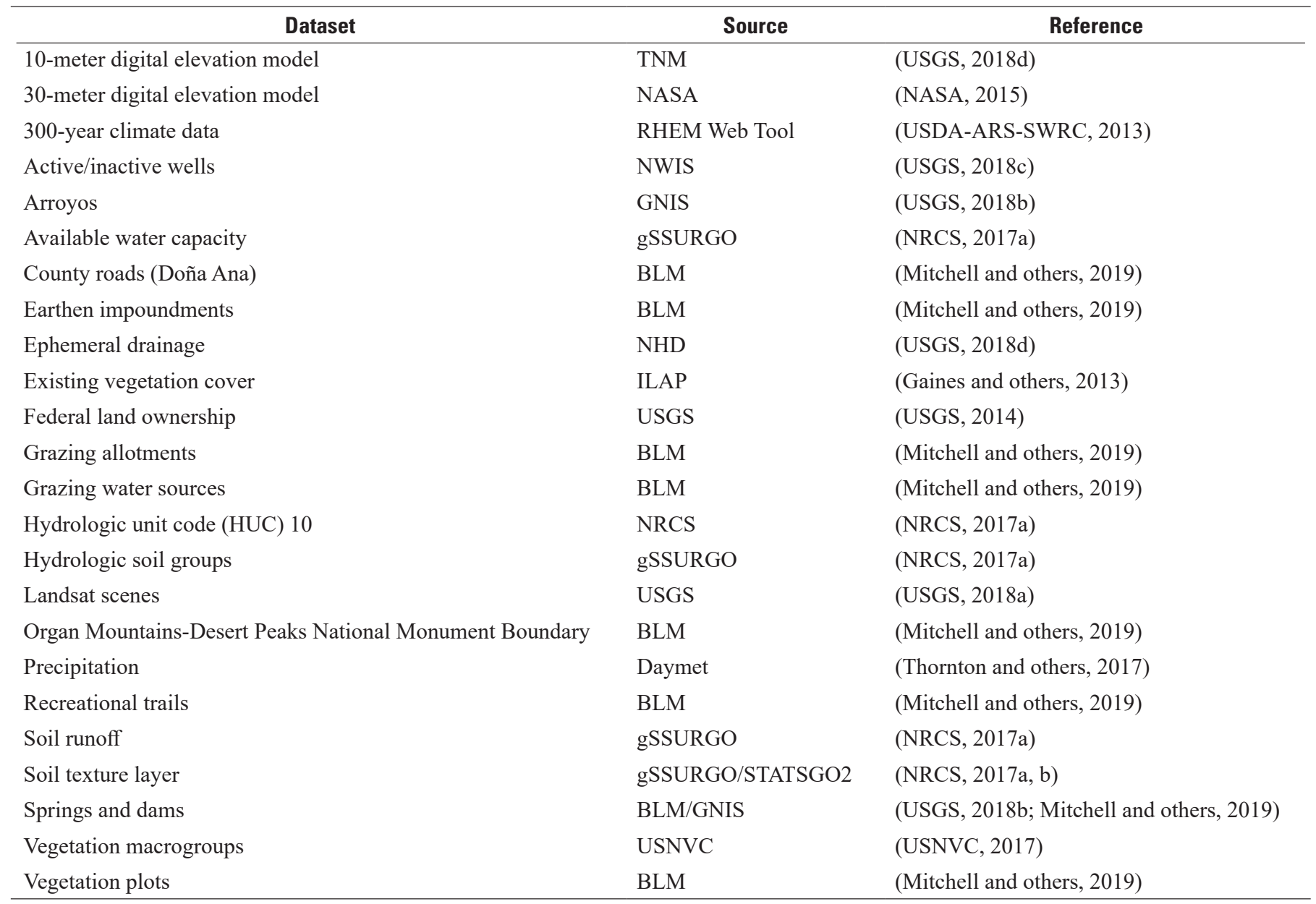


Weathering indices include elements that have consistent geochemical behavior during weathering and are not affected by oxidation (Harnois, 1988). The indices used are as follows:

1. Chemical index of weathering (CIW) (Harnois, 1988)

$$
\mathrm{CIW}=\left[\mathrm{Al}_{2} \mathrm{O}_{3} /\left(\mathrm{Al}_{2} \mathrm{O}_{3}+\mathrm{CaO}+\mathrm{Na}_{2} \mathrm{O}\right)\right] \times 100
$$

2. Chemical index of alteration (CIA) (Nesbitt and Young, 1982)

$$
\mathrm{CIA}=\left[\mathrm{Al}_{2} \mathrm{O}_{3} /\left(\mathrm{Al}_{2} \mathrm{O}_{3}+\mathrm{CaO}+\mathrm{Na}_{2} \mathrm{O}+\mathrm{K}_{2} \mathrm{O}\right)\right] \times 100
$$

3. Weathering index of Parker (WIP) (Parker, 1970)

$$
\begin{aligned}
& \mathrm{WIP}=\left[\left(2 \mathrm{Na}_{2} \mathrm{O} / 0.35\right)+(\mathrm{MgO} / 0.9)+\right. \\
& \left.\left(2 \mathrm{~K}_{2} \mathrm{O} / 0.25\right)+(\mathrm{CaO} / 0.7)\right] \times 100
\end{aligned}
$$

4. Modified weathering potential index (MWPI) (Reiche [1943], modified by Vogel [1975])

$$
\begin{gathered}
\text { MWPI }=\left[\left(\mathrm{Na}_{2} \mathrm{O}+\mathrm{K}_{2} \mathrm{O}+\mathrm{CaO}+\mathrm{MgO}\right) /\right. \\
\left.\left(\mathrm{Na}_{2} \mathrm{O}+\mathrm{K}_{2} \mathrm{O}+\mathrm{CaO}+\mathrm{MgO}+\mathrm{SiO}_{2}+\mathrm{Al}_{2} \mathrm{O}_{3}+\mathrm{Fe}_{2} \mathrm{O}_{3}\right)\right] \times 100
\end{gathered}
$$

5. Vogt ratio (V) (Roaldset, 1972)

$$
\mathrm{V}=\left(\mathrm{Al}_{2} \mathrm{O}_{3}+\mathrm{K}_{2} \mathrm{O}\right) /\left(\mathrm{MgO}+\mathrm{CaO}+\mathrm{Na}_{2} \mathrm{O}\right)
$$

where

$\begin{aligned} \mathrm{Al}_{2} \mathrm{O}_{3} & \text { is aluminum oxide, } \\ \mathrm{CaO} & \text { is calcium oxide, } \\ \mathrm{K}_{2} \mathrm{O} & \text { is potassium oxide, } \\ \mathrm{Fe}_{2} \mathrm{O}_{3} & \text { is iron oxide, } \\ \mathrm{MgO} & \text { is magnesium oxide, } \\ \mathrm{Na}_{2} \mathrm{O} & \text { is sodium oxide, and } \\ \mathrm{SiO}_{2} & \text { is silicon oxide. }\end{aligned}$

Each index was calculated using the specified element's molecular proportion.

The potential for physical weathering to occur can be qualitatively evaluated by knowing rock type and the general effect that the common physical processes can have on each rock type. In addition, physical weathering tends to increase at higher elevation. In this study, rock types were grouped in a
GIS and described based on the potential for physical weathering according to type and location.

\section{Landform Maps}

Landform maps were created by using a combination of DEMs (NASA, 2015) and satellite imagery (USGS, 2018a) to create two detailed landform maps for each of the four subunits. Major landforms identified included alluvial fan plains, arroyos, hillslopes, and mountains (table 4). Landform features were identified by using the Hammond-Dikau method (Dikau and others, 1991), and topographical features were identified by using a pattern-recognition-based approach applied in GRASS GIS (GRASS Development Team, 2017).

The Hammond-Dikau method was chosen because of its prior use in New Mexico in the 1990s to find landforms in desert landscapes similar to those observed in the Organ Mountains and its USGS development background (Dikau and others, 1991). Four 30-m DEMs were downloaded from the National Aeronautics and Space Administration (NASA) Earthdata Search website (NASA, 2015) and merged by using ArcMap 10.4.1 (Esri, 2015). Hydrologic unit code 10 (HUC10) boundaries that intersected each of the four Monument subunits, Desert Peaks, Doña Ana, Organ Mountains, and Potrillo, were chosen to represent each subunit boundary for the layers, and the DEMs were clipped to these HUC10 boundaries to create three input layers needed for the Hammond-Dikau landform model (Morgan and Lesh, 2005). The input layers included a profile input, a slope input, and a relief input raster. The model then was run to finalize the HammondDikau landform maps.

The Hammond-Dikau method creates maps with broad landform categories. To refine these categories and to produce more detailed maps that included arroyos and other major landforms, a pattern-recognition approach was used (GRASS Development Team, 2017). Using a 10-m DEM, a geomorphon script within GRASS GIS was run to identify the 10 most common geomorphons, or topographic features. The GRASS script was edited to evaluate 1,500 cells around each individual cell and was run to find patterns, produce more detailed topographic features, and determine the geomorphon of the pixel (Jasiewicz and Stepinski, 2012).

Both the Hammond-Dikau method and the pattern-based GRASS GIS approach produced broad categories of landforms, although the GRASS GIS approach produced higher resolution maps. Both methods were used to highlight differences between digital GIS-based methods for determining landforms. To determine general landforms, major landforms 
Table 4. Common landforms found in the southwestern United States and their definitions.

\begin{tabular}{|c|c|}
\hline Landform & Definition \\
\hline Alluvial fan & $\begin{array}{l}\text { A fan shaped or triangular pattern of sand, gravel, or other sediment that is spread by water over an area of the ground, } \\
\text { hillside, or mountain. A body of detrius formed at the outlet of a mountain valley (Mabbutt, 1977; Bierman and Mont- } \\
\text { gomery, 2014; World Landforms, 2015). }\end{array}$ \\
\hline Arroyo & $\begin{array}{l}\text { A creek or river bed that is sometimes dry due to an inconsistent water source. Steep-sided gullies (Mabbutt, 1977; } \\
\text { World Landforms, 2015). }\end{array}$ \\
\hline Basin & $\begin{array}{l}\text { A basin is a hollow or depression in the earth's surface, wholly or partly surrounded by higher land such as a river basin. } \\
\text { Lowlands/Tablelands (Mabbutt, 1977; World Landforms, 2015). }\end{array}$ \\
\hline Braided river & $\begin{array}{l}\text { A river that has three or more channels that may come together again, or drain into the same body of water (World } \\
\text { Landforms, 2015). }\end{array}$ \\
\hline Canyon & $\begin{array}{l}\text { Two steep cliffs with a valley running between them. There is often a river that runs through the two (World Landforms, } \\
\text { 2015). }\end{array}$ \\
\hline Dunes & $\begin{array}{l}\text { A deposit of sand- or silt-sized grains that was carried by wind. Can reflect different sand-transport processes and bound- } \\
\text { ary conditions (Bierman and Montgomery, 2014). }\end{array}$ \\
\hline Hillslope & An undisected upland between valleys that functions as a sediment source (Bierman and Montgomery, 2014). \\
\hline Lava field & One or more flows of lava over a flat area of land, covering all or most of the area (World Landforms, 2015). \\
\hline Mountain & $\begin{array}{l}\text { A natural elevation of the earth's surface rising more or less abruptly to a summit, and attaining an altitude greater than } \\
\text { that of a hill, usually greater than } 2,000 \text { feet (World Landforms, 2015). }\end{array}$ \\
\hline Plain & A flat or gently rolling landform and can cover many miles (World Landforms, 2015). \\
\hline Plateau & An area that is raised above other surrounding lands and is generally flat and level (World Landforms, 2015). \\
\hline Playa & Salt and mud flats that were once shallow and saline lakes (Bierman and Montgomery, 2014). \\
\hline Pond & A small body of water, generally smaller than a lake (World Landforms, 2015). \\
\hline Reservoir & A lake where water is collected and stored for future use (World Landforms, 2015). \\
\hline
\end{tabular}

present in semi-arid climates and desert environments (Mabbutt, 1977) were cross referenced with geologic and soil data and a matrix was created that includes the landform definitions (table 4). Each of the 10 geomorphons from the pattern-based approach then were associated with the major landforms that each geomorphon may represent (table 5) to allow for a simpler understanding of what each topographic feature may be.

\section{Infiltration Potential Index}

The infiltration potential index (IPI) system was used to quantify infiltration potential in the Monument. The IPI is a geospatial analysis technique adapted from the infiltration potential in Brito and others (2006) and is used to identify areas of relatively high or low land-surface infiltration potential. The finished product is a raster or gridded-cell file that qualitatively characterizes each cell in the study area on a scale ranging from low ( 0 percent) to high (100 percent) IPI. Conversely, the IPI may also indicate areas in the Monument ranging from high $(I P I=0$ percent $)$ to low $(I P I=100$ percent $)$ susceptibility to surface runoff and erosion. The IPI is estimated from soil, slope, and vegetation geospatial data. Precipitation intensity may also determine whether infiltration occurs (Horton, 1933, 1940); however, IPI is limited to representing the ground conditions that may facilitate infiltration, independent of the rainfall intensity conditions. However, rainfall intensities tend to be relatively high in this region because of the monsoonal-driven precipitation in the study area. The DEM data used were from the NASA Earthdata Search 
Table 5. GRASS GIS geomorphons associated with common landforms.

[NRCS, Natural Resources Conservation Service]

\begin{tabular}{|c|c|c|}
\hline $\begin{array}{l}\text { GRASS GIS } \\
\text { geomorphon }\end{array}$ & $\begin{array}{c}\text { Associated } \\
\text { defined landforms }\end{array}$ & $\begin{array}{l}\text { GRASS GIS } \\
\text { topographical definitions }\end{array}$ \\
\hline Flat & Plateau, terrace, lava field & $\begin{array}{l}\text { Continuous surface or stretch of land that is smooth, even, or horizontal, or nearly so, } \\
\text { and lacks any significant curvature, slope, elevations, or depressions (NRCS, 2018). }\end{array}$ \\
\hline Summit & Mountain, volcano, high hill & $\begin{array}{l}\text { Highest position of a hillslope profile with a nearly level (planar or only slightly convex) } \\
\text { surface (NRCS, 2018). }\end{array}$ \\
\hline Ridge & Hills, mountain, ridge & $\begin{array}{l}\text { Long, narrow elevation of the land surface, usually sharp crested with steep sides and } \\
\text { forming an extended upland between valleys (NRCS, 2018). }\end{array}$ \\
\hline Shoulder & Hills, hillslope & $\begin{array}{l}\text { The hillslope profile position that forms the convex, erosional surface near the top of a } \\
\text { hillslope (NRCS, 2018). }\end{array}$ \\
\hline Spur & Hills, mountain, spur, ridge & $\begin{array}{l}\text { A subordinate ridge or lesser elevation that projects sharply from the crest or side of a } \\
\text { hill, mountain, or other prominent range of hills or mountains (NRCS, 2018). }\end{array}$ \\
\hline Slope & Hillslope, hill, mountainside & $\begin{array}{l}\text { The inclination of the land surface from the horizontal (NRCS, 2018), typically observed } \\
\text { between a higher elevation and lower elevation landform. }\end{array}$ \\
\hline Valley & $\begin{array}{l}\text { Valley, arroyo, alluvial fan, } \\
\text { river, braided river }\end{array}$ & $\begin{array}{l}\text { An elongate, relatively large, externally drained depression of the Earth's surface that is } \\
\text { primarily developed by stream erosion or glacial activity (NRCS, 2018). }\end{array}$ \\
\hline Depression & $\begin{array}{l}\text { Basin, arroyo, alluvial fan, } \\
\text { river, braided river }\end{array}$ & $\begin{array}{l}\text { Any relatively sunken part of the Earth's surface; a low-lying area surrounded by higher } \\
\text { ground, may have natural outlet for surface drainage (NRCS, 2018). }\end{array}$ \\
\hline
\end{tabular}

website (NASA, 2015), and soils data were retrieved from the NRCS Soil Survey Geographic Database (SSURGO). Each of these physical parameters plays an important role in determining how much water will infiltrate into the land surface or contribute to surface runoff.

A weighted overlay analysis used a GIS to determine the IPI throughout the Monument by adapting the methodology of Brito and others (2006) in an aquifer infiltration assessment to focus on infiltration potential in soils. The overlay analysis used three input rasters containing soils, slope, and vegetation data. These rasters were reclassified on a linear scale from 0 to 100 percent and weighted based on their relative importance in the infiltration process. The rasters then were overlaid and summed at each cell location (eq. 6).

$$
I P I(X o)=\sum_{i=1}^{N}\left[W_{i} P_{i}(X o)\right]
$$

where

$$
\begin{aligned}
& \text { IPI is the infiltration potential index at location } \\
& X o \text { (IPI ranges from } 0 \text { to } 100 \text { percent), } \\
& N \quad \text { is the number of parameters }(N=3 \text { in this } \\
& \text { study: soils, slope, and vegetation), } \\
& \text { is the parameter number ( } 1 \text { to } N \text { ), } \\
& W_{i} \quad \text { is the weight applied to parameter } i\left(W_{1}+W_{2}\right. \\
& \left.+W_{3}=1.0\right) \text {, and } \\
& P_{i}(X o) \quad \text { is the parameter } i \text { at location } X o\left(P_{i}\right. \text { ranges } \\
& \text { from } 0 \text { to } 100 \text { percent). }
\end{aligned}
$$

The sections Soils $\left(P_{1}\right)$, Slope $\left(P_{2}\right)$, and Vegetation $\left(P_{3}\right)$ in this report contain a detailed justification for the reclassification schemes used in this study. Parameter weights were determined by selecting 1 of 10 weighting schemes, whose output most closely resembled the hydraulic conductivity $\left(K_{e}\right)$ values determined by the RHEM in a relative sense.

\section{Soils $\left(P_{1}\right)$}

Soil infiltration capacity can be a determining factor in how much runoff contributes to overland flow. Soils were categorized into one of four hydrologic soil groups (A, B, C, or D) by the original SSURGO dataset based on their potential for water infiltration when thoroughly wet (NRCS, 2009):

- Group A: Soils having a high infiltration rate (lowest runoff potential);

- Group B: Soils having a moderate infiltration rate;

- Group C: Soils having a low infiltration rate; and

- Group D: Soils having a very low infiltration rate (highest runoff potential).

Each hydrologic soil group was assigned a range of saturated hydraulic conductivity $\left(K_{s a t}\right)$ values (NRCS, 2009). For soils with an impermeable layer at depths greater than 40 in. $(102 \mathrm{~cm})$, saturated hydraulic conductivities are defined as follows: 
- Group A: Greater than (>) 1.42 inches/hour (in/h) (3.61 centimeters per hour $[\mathrm{cm} / \mathrm{h}]$ );

- Group B: 0.57 to $1.42 \mathrm{in} / \mathrm{h}(1.45$ to $3.61 \mathrm{~cm} / \mathrm{h})$;

- Group C: 0.06 to $0.57 \mathrm{in} / \mathrm{h}(0.15$ to $1.45 \mathrm{~cm} / \mathrm{h})$; and

- Group D: Less than $(<) 0.06 \mathrm{in} / \mathrm{h}(0.15 \mathrm{~cm} / \mathrm{h})$.

The soils raster was reclassified based on assigned (near-average) $K_{\text {sat }}$ values for each soil group (table 6). The soils layer was given a weight $\left(W_{1}\right)$ of 0.2 .

\section{Slope $\left(P_{2}\right)$}

Sheet flow velocities and runoff coefficients have been found to generally increase with an increasing slope gradient because of increased gravitational forces oriented parallel to slope direction (Pei and Bin, 2011; She and others, 2014; Zhuang and others, 2018). Runoff coefficients (the ratios between precipitation and runoff for given events) may increase up until a certain slope threshold is reached, after which the coefficient may stay constant or decrease. As slope increases, the hillslope land-surface area covers a decreasing

Table 6. Classification of the soils parameter $\left(P_{1}\right)$ in the infiltration potential index (IPI) used to identify areas of relatively high or low land-surface infiltration potential in the Organ Mountains-Desert Peaks National Monument, New Mexico.

$\left[K_{\text {sat }}\right.$, saturated hydraulic conductivity; in/h, inch per hour; >, greater than; $\leq$, less than or equal to]

\begin{tabular}{ccccc}
$\begin{array}{c}\text { Hydrologic } \\
\text { soil group }\end{array}$ & $\begin{array}{c}\text { Saturated } \\
\text { hydraulic con- } \\
\text { ductivity }\left(\boldsymbol{K}_{\text {sat }}\right) \\
\text { (in/h) }\end{array}$ & $\begin{array}{c}\text { Assigned } \\
\boldsymbol{K}_{\text {sat }} \\
\text { (in/h) }\end{array}$ & $\begin{array}{c}\text { Ratio } \\
\text { to soil } \\
\text { group A }\end{array}$ & $\begin{array}{c}\boldsymbol{P}_{\mathbf{1}} \\
\text { (percent) }\end{array}$ \\
\hline A & $>1.42$ & 1.5 & 1 & 100 \\
B & $0.57-1.42$ & 0.995 & 0.66 & 66 \\
C & $0.06-0.57$ & 0.315 & 0.21 & 21 \\
D & $\leq 0.06$ & 0.05 & 0.03 & 3 \\
\hline
\end{tabular}

Table 7. Classification of the slope parameter $\left(P_{2}\right)$ in the infiltration potential index (IPI) used to identify areas of relatively high or low land-surface infiltration potential in the Organ Mountains-Desert Peaks National Monument, New Mexico.

[>, greater than]

\begin{tabular}{cc}
\hline $\begin{array}{c}\text { Slope range } \\
\text { (percent) }\end{array}$ & $\begin{array}{c}\boldsymbol{P}_{2} \\
\text { (percent) }\end{array}$ \\
\hline $0-5$ & 97.5 \\
$5-10$ & 92.5 \\
$10-15$ & 50.0 \\
$>20$ & 45.0 \\
\hline
\end{tabular}

area orthogonal to the direction of rainfall, so that the raindrops are spread over a greater land surface (fewer raindrops per land area), thus the opportunity for infiltration increases and runoff decreases. When the slope threshold is reached, the decreased precipitation per land area outweighs the gravitational effects, and more infiltration is likely (Pei and Bin, 2011; Zhuang and others, 2018). Pei and Bin (2011) found that the critical slope gradient for the runoff coefficient is between 17.6 percent and 36.4 percent (10 and 20 degrees), in agreement with Zhuang and others (2018), who found that the critical gradient for sheet flow velocities was reached when the slope was between 10 and 20 degrees. The relation between slope and runoff was found to be exponential up to the threshold (Pei and Bin, 2011).

A slope raster was created from a filled 30-m resolution DEM by using the ArcMap 10.4 Slope tool (Esri, 2015). Slope varied between zero and approximately 69 percent within the study area. An upper limit threshold of 20 degrees was used based upon the results of Pei and Bin (2011) and Zhuang and others (2018). The slope raster was reclassified based on this threshold and the relation between slope and runoff in Pei and Bin (2011; table 7). Slope was assigned the weight $\left(W_{2}\right)$ of 0.2 .

\section{Vegetation $\left(P_{3}\right)$}

Vegetation can increase infiltration by increasing surface roughness and reducing soil bulk densities (Belsky and others, 1993 ) with a corresponding increase in porosity (Mankin and others, 1996) and an increasing density of macropores (Dunne and others, 1991). In addition, vegetation cover may intercept raindrops, which can reduce the amount of water that reaches the ground surface and reduce the likelihood that sediment particles will be disaggregated from high-energy raindrop impacts and reworked to seal soil surfaces (McIntyre, 1958; Dunne and others, 1991). A raster of percentage of vegetation cover at each pixel was used as the vegetation layer. The percent cover data were the same data used in the RHEM for this study and were derived by using the normalized difference vegetation index (NDVI) and elevation. Percentage of vegetation was already characterized on a linear scale with a potential minimum of 0 percent and potential maximum of 100 percent, so the data were not reclassified. The $P_{3}$ values then became the percent cover values. Vegetation was assigned a weight $\left(W_{3}\right)$ of 0.6 .

\section{Effects of Roads and Trails}

To understand the role of roads and trails in the Monument, the watershed condition classification (WCC) system (Potyondy and Geier, 2011) was used in this study. The WCC was created by the USDA as a standardized and nationally consistent approach to classify watershed health conditions of all National Forest System watersheds and was used in this study to determine the effects of infrastructure, including roads and trails, on potential vulnerability in the watershed. The goal 
of the WCC is to provide a tool that helps strategically prioritize watershed improvement project investments on relatively degraded watersheds (Potyondy and Geier, 2011). The WCC classifies watersheds into three functionality classes:

- Class $1=$ Functioning properly;

- Class $2=$ Functioning at risk; and

- Class 3 = Impaired function.

The WCC system focuses on 12 indicators of watershed function: water quality, water quantity, aquatic habitat, aquatic biota, riparian/wetland vegetation, roads and trails, soils, fire regime or wildfire, forest cover, rangeland vegetation, terrestrial invasive species, and forest health. These 12 indicators are assessed and weighted to give an overall measure of watershed function. Not all 12 indicators are relevant for the current study area. Water quality, water quantity, aquatic habitat, aquatic biota, riparian/wetland vegetation, fire regime or wildfire, forest cover, terrestrial invasive species, and forest health indicators were not relevant to the study area or did not pertain to the objectives of this study. Soils and rangeland vegetation are discussed in other sections. Thus, this section focuses on the roads and trails indicator.

The roads and trails indicator of the WCC system (Potyondy and Geier, 2011) rates watershed function based on open-road/trail density and proximity to water. For a Class 1 watershed (functioning properly), these values are less than $(<) 1$ mile per square mile $\left(\mathrm{mi} / \mathrm{mi}^{2}\right)$ of open roads/trails and $<10$ percent of total road length within $300 \mathrm{ft}$ of water. For a Class 2 watershed (functioning at risk), these values are 1 to $2.4 \mathrm{mi} / \mathrm{mi}^{2}$ and 10 to 25 percent of total road length within $300 \mathrm{ft}$ of water, and for a Class 3 watershed (impaired function), these values are $>2.4 \mathrm{mi} / \mathrm{mi}^{2}$ and $>25$ percent. Because of the monsoonal-driven flow patterns in the study area, the guideline for proximity to water was modified to also include roads in proximity to ephemeral channels. Additional guidelines for road and trail maintenance best management practices and for gravity-driven transport of sediment because of roads on unstable landforms or rock types prone to mass wasting were not included in this analysis.

Spatial analysis of road features was conducted with ArcGIS 10.4.1 for Desktop (Esri, 2015). A polygon shapefile was created to represent areas within $300 \mathrm{ft}$ of each ephemeral drainage by using the ArcMap Buffer geoprocessing tool. The ephemeral drainage feature class was then set as the input feature with a $300-\mathrm{ft}$ linear unit buffer. The Clip Tool and an additional line shapefile of roads within the Monument were used to identify road sections that intersected with the buffer ephemeral drainage shapefile. The shape length outputs generated by the geoprocessing tools from the original and new intersecting roads shapefiles were used to calculate the percentage of all Monument roads within $300 \mathrm{ft}$ of ephemeral drainages.

\section{Rangeland Hydrology Erosion Model (RHEM)}

For this study we used the RHEM (Nearing and others, $2011)$ to estimate runoff and erosion. The RHEM is a processbased, single-event runoff and erosion model developed by the U.S. Department of Agriculture, Agricultural Research Service, Southwest Watershed Research Center (USDA-ARSSWRC) (2013) that applies infiltration and erosion equations from the Water Erosion Prediction Project (WEPP) model (Flanagan and Nearing, 1995; Flanagan and others, 2012) and adapts them to rangeland conditions. The RHEM was parameterized and calibrated using data from more than 200 plots at 49 rangeland sites across 15 western States (Nearing and others, 2011). The model requires site-specific data on climate, slope, soil texture, and vegetation and ground cover; the model outputs consist of annual average runoff, soil loss, and sediment yield. The RHEM provides insight into how vegetation cover and management practices might affect rangeland runoff and erosion. The model was previously applied to individual semi-arid rangeland sites in southern New Mexico and southeastern Arizona using plot data (Webb and others, 2014; Hernandez and others, 2017). Land managers often require information across the landscape rather than just for individual plots. The objective for this study was to develop and demonstrate a method to apply plot-scale vegetation and ground cover data to a broader landscape.

\section{Developing RHEM Parameters}

Plot data utilized to parameterize the RHEM model consisted of line-point intercept data collected in 2016 by BLM. Data were collected along three $82-\mathrm{ft}(25-\mathrm{m})$ transects (oriented at 120-degree intervals) at 66 plots in and around the Monument between August 3 and December 1, 2016. Plot data were obtained from the Database for Inventory, Monitoring, and Assessment, which is jointly maintained by the U.S. Department of Agriculture, Agricultural Research Service (USDA-ARS), USDA NRCS, and BLM (The Jornada, 2016). Foliar cover and ground cover intersecting each transect were recorded in 10-in. $(25-\mathrm{cm})$ intervals according to standard methods (Herrick and others, 2005a, b). The line-intercept method differentiated between foliar cover and ground cover. Foliar cover was defined as the percentage of ground covered by the vertical projection of the aerial portion of plants (Anderson, 1986) and were recorded as percent cover, by species, for each plot. Ground cover categories included bare ground, litter, rock, basal stems, and biological crusts and bacteria and were also recorded as percent cover, by category, for each plot.

A 30-m DEM was obtained from the USGS EarthExplorer (USGS, 2018a), and a slope layer was derived from the elevation DEM by using a GIS. A continuous Monument-wide soil texture layer was created from two publicly available soil data layers: gSSURGO and STATSGO2. Both datasets were obtained from the USDA NRCS Geospatial Data Gateway (NRCS, 2017a, b, 2018). NRCS soil textures with additional descriptive qualifiers were recoded into RHEM soil texture categories (table 8). 
Table 8. Soil texture correspondence between RHEM and NRCS STATSG0/gSSURG0 categories (Natural Resources Conservation Service, 2017a, b, 2018).

[RHEM, Rangeland Hydrology and Erosion Model; STATSGO2, U.S. General Soil Map dataset; gSSURGO, Gridded Soil Survey Geographic Database]

\begin{tabular}{ll}
\hline \multicolumn{1}{c}{ RHEM soil texture } & \\
\hline Clay & Clay \\
Clay loam & Clay loam, very cobbly clay loam \\
Loam & Loam \\
Loamy sand & Loamy sand, loamy fine sand, loamy very fine sand \\
Sand & Fine sand, sand \\
Sandy clay loam & Sandy clay loam \\
Sandy loam & Sandy loam, fine sandy loam, gravelly fine sandy loam, very gravelly fine sandy loam, very gravelly sandy loam \\
Silt loam & Silt loam \\
Silty clay loam & Silty clay loam \\
\hline
\end{tabular}

Ground cover was classified by using the USNVC (2017). Eight USNVC vegetation macrogroups were within the Monument (tables 1 and 9). Five macrogroups, Madrean Lowland Evergreen Woodland (M010), Madrean Montane Forest and Woodland (M011), Warm Semi-Desert Cliff, Scree and Rock Vegetation (M117), North American Warm-Desert Xeric-Riparian Scrub (M092), and Warm and Cool Desert Riparian Woodland (M036), were merged with their nearest neighbor due to the minimal area they represented within the Monument (table 9) and (or) lack of plot transect data. Thus, this study focused on the three remaining majority vegetation macrogroups: Chihuahuan Desert Scrub (M086), Chihuahuan Semi-Desert Grassland (M087), and North American Warm Desert Ruderal Scrub and Grassland (M512).

Table 9. Vegetation macrogroups in the Organ Mountains-Desert Peaks National Monument, areas covered by each, and number of plots used to develop RHEM parameters.

[RHEM, Rangeland Hydrology and Erosion Model; $\mathrm{mi}^{2}$, square mile]

\begin{tabular}{lcc}
\hline \multicolumn{1}{c}{$\begin{array}{c}\text { Vegetation macrogroup } \\
\text { (fig. 3) }\end{array}$} & $\begin{array}{c}\text { Area } \\
\left(\mathbf{m i}^{\mathbf{2}}\right)\end{array}$ & $\begin{array}{c}\text { Number } \\
\text { of plots }\end{array}$ \\
\hline $\begin{array}{l}\text { (M010) Madrean Lowland Evergreen } \\
\text { Woodland }\end{array}$ & 20.1 & 0 \\
$\begin{array}{l}\text { (M011) Madrean Montane Forest and } \\
\text { Woodland }\end{array}$ & 0.69 & 0 \\
$\begin{array}{l}\text { (M036) Warm and Cool Desert Riparian } \\
\text { Woodland }\end{array}$ & 0.07 & 0 \\
$\begin{array}{l}\text { (M086) Chihuahuan Desert Scrub } \\
\text { (M087) Chihuahuan Semi-Desert Grass- } \\
\text { land }\end{array}$ & 339 & 266 \\
(M092) North American Warm-Desert \\
$\quad \begin{array}{l}\text { Xeric-Riparian Scrub } \\
\text { (M117) Warm Semi-Desert Cliff Scree } \\
\text { and Rock Vegetation }\end{array}$ \\
$\begin{array}{l}\text { (M512) North American Warm Desert } \\
\text { Ruderal Scrub \& Grassland }\end{array}$ & 54.2 & 0 \\
\hline
\end{tabular}

A Landsat 8 scene from September 18, 2016 (USGS, 2018a) was used to calculate the NDVI layer for the Monument. This Landsat scene corresponded to the peak of the 2016 monsoon season, showed the greenest vegetation of the year, was within the transect data collection period, and represented the best cloud-free scene. The NDVI was calculated by using Landsat 8 Operational Land Imager sensor Band 4 (visible red, $0.636-0.673$ micrometers $[\mu \mathrm{m}]$ ) and Band 5 (near infrared, $0.851-0.879 \mu \mathrm{m})$.

$$
\mathrm{NDVI}=(\text { Band } 5-\text { Band } 4) /(\text { Band } 5+\text { Band } 4)
$$

The climate record from the Jornada Experimental Range climate station (station number 294426) was obtained from the RHEM Web Tool (https://apps.tucson.ars.ag.gov/rhem/, USDA Southwest Watershed Research Center, 2013) and used for the Monument climate record because of its proximity to the Monument (fig. 3 and analogous climate). The climate record was derived from the CLIGEN model (Zhang and Garbrecht, 2003 ) to generate daily rainfall statistics for a 300 -year period for use in the rainfall disaggregation component of the RHEM.

Spatial analysis and parameterization were conducted in ArcGIS 10.4.1 for Desktop (Esri, 2015) and RStudio 3.4.1 (RStudio, 2015). The soil layer and the vegetation macrogroup layer were clipped to the Monument boundaries and combined by using the ArcMap Intersect tool to create a base layer. A 656-ft (200-m) grid was intersected with the base layer, and the Zonal Statistics to Table ArcMap tool was used to extract elevation, slope, and NDVI for each grid cell in the Monument. Cells with a standard deviation of $\geq 3.0$ percent slope were subdivided to a $328-\mathrm{ft}(100-\mathrm{m})$ grid to ensure a representative modeling environment. Cells smaller than 108,000 square feet $\left(\mathrm{ft}^{2}\right)\left(1,000\right.$ square meters $\left.\left[\mathrm{m}^{2}\right]\right)$ were removed from the final layer because of edges and overlapping intersection areas; this reduced the number of individual cells by more than half without sacrificing model resolution. The final Monument geospatial layer consisted of 168,276 cells 
and contained the following data: elevation, slope, soil texture, vegetation macrogroup, and NDVI.

The transect plots in 2016 were distributed across the three main vegetation macrogroups in the Monument (table 9). Plot transect data were recoded to RHEM-specific categories. Plant species were recorded and summed into the corresponding foliar cover group: shrubs, bunch grass, sod grass, or forbs. Cover for each foliar category was calculated by averaging the foliar cover for all species in that category for each vegetation macrogroup (table 10). Ground cover data were aggregated into one of four categories (litter, rock, basal stems, and biological crusts; table 11) and averaged for each vegetation macrogroup.

A multiple linear regression model (Helsel and Hirsch, 2002) was developed for total foliar cover as a function of elevation and NDVI for an area-weighted average of the cells overlapping the $98-\mathrm{ft}(30-\mathrm{m})$ radius plot area (table 12$)$. Similarly, multiple linear regression equations were developed for litter cover and rock cover as a function of slope and total foliar cover for each 98-ft (30-m) radius plot area (table 12).

Total foliar cover, litter cover, and rock cover were calculated for each cell in the Monument by using the regression models (table 12). Data for 2016 transect plots within each vegetation macrogroup were used to calculate average percent cover for each foliar cover group (shrubs, bunch grass, sod grass, and forbs; table 10) and each ground cover group (table 11). The fraction of each foliar cover group for each model cell was calculated as the product of the average foliar group percentage (table 10) and the regressed total foliar cover fraction for that cell (table 12). Each cell was assigned rock cover and litter cover from the best-fit regression models (table 12), basal stem cover from the average for the appropriate macrogroup (table 11), and total ground cover from the sum of rock, litter, and basal stem cover for that cell.

For each model cell, the effective hydraulic conductivity $\left(K_{e}\right)$ was calculated for each soil type and foliar cover group in the cell as a function of basal cover and litter cover by using the method of Hernandez and others (2017). Splash and sheet erosion factor $\left(K_{s s}\right)$ for each cell was calculated as a function of foliar cover, ground cover, and slope and then aggregated by areal fraction of each foliar cover group for each grid cell, with modifications according to relative foliar and ground cover (Al-Hamdan and others, 2017). The friction factor $\left(F_{t}\right)$ for each cell was calculated as a function of the ground cover characteristics and slope (Hernandez and others, 2017).

A dataset of 15,660 unique combinations of vegetation macrogroup, slope, total foliar cover, and soil texture was developed representing conditions across the Monument. A script was developed to calculate $K_{e}, K_{s s}$, and $F_{t}$ for each unique combination and then to run the RHEM for each instance. Model results were spatially distributed to corresponding cells throughout the Monument for mapping and analysis. The model input and output files are available in the associated data release (Mitchell and others, 2019). A method assessment of the approach is documented in Ball and Douglas-Mankin (2019).

\section{RHEM Scenarios}

Five scenarios were created in the RHEM to calculate potential effects on runoff and erosion within the Monument based on changes in total foliar cover and the following changes to each foliar group (bunch grass, forbs, shrubs, and sod grass). Scenario 1 represented defined climatic baseline conditions from which subsequent scenarios were compared. Scenarios 2 and 3 represented a sensitivity test of plus or minus 20 percent vegetation cover across the monument, respectively. The 20 -percent change in total foliar cover was chosen as the magnitude of change for runoff, and erosion values were easily interpreted. Scenario 4 assessed rangeland response to severe drought or heavy grazing pressure. Nonwoody vegetation groups (bunch grass, forbs, and sod grass) were reduced by 40 percent while maintaining shrub cover at baseline conditions. Scenario 5 assessed the transition of the Chihuahuan Desert from grassland to a shrub-dominated ecosystem. Total foliar cover was kept at baseline conditions while reducing nonwoody vegetation groups by 40 percent and increasing the shrub cover proportionally.

\section{Scenario 1: Baseline Conditions, 2016}

Scenario 1 (baseline conditions) represents the estimated baseline conditions at the Monument during the 2016 monsoon season. The Landsat scene used to characterize foliar cover across the Monument was imaged on September 18, 2016, and represents the peak of the 2016 growing season for rangeland vegetation and the strongest NDVI signal for model parameterization. Precipitation in the Monument area for 2015 was above average (12.6 in.) with a weak monsoon (4.8 in., 38 percent of total annual precipitation), whereas precipitation for 2016 was below average (8.4 in.) with a stronger monsoon (5.2 in., 61 percent of total annual precipitation) (NOAA, 2018). Despite below-average precipitation for 2016, the monsoonal total was greater than half of the total annual precipitation, resulting in an overall average monsoon season. As such, the 2016 baseline scenario may be representative of normal monsoonal precipitation levels and vegetation conditions. 
Table 10. Average percent foliar cover plus or minus standard deviations for plot data and ratios of each foliar category to total foliar cover by vegetation macrogroup.

$[\%$, percent; \pm , plus or minus $]$

\begin{tabular}{|c|c|c|c|c|c|c|c|c|c|c|}
\hline \multirow{2}{*}{$\begin{array}{c}\text { Vegetation } \\
\text { macrogroup } \\
\text { (see table 9) }\end{array}$} & \multirow{2}{*}{$\begin{array}{l}\text { Number } \\
\text { of plots }\end{array}$} & \multirow{2}{*}{$\begin{array}{c}\text { Total foliar } \\
(\%)\end{array}$} & \multicolumn{2}{|c|}{ Shrubs } & \multicolumn{2}{|c|}{ Bunch grass } & \multicolumn{2}{|c|}{ Sod grass } & \multicolumn{2}{|c|}{ Forbs } \\
\hline & & & $(\%)$ & Ratio & $(\%)$ & Ratio & $(\%)$ & Ratio & $(\%)$ & Ratio \\
\hline M086 & 18 & $36.0 \pm 15.4$ & $17.0 \pm 9.5$ & 0.47 & $10.8 \pm 11.2$ & 0.3 & $6.1 \pm 1.6$ & 0.04 & $6.9 \pm 6.3$ & 0.19 \\
\hline M087 & 24 & $52.3 \pm 23.2$ & $11.6 \pm 10.0$ & 0.22 & $23.2 \pm 22.8$ & 0.44 & $11.5 \pm 20.2$ & 0.22 & $6.4 \pm 6.1$ & 0.12 \\
\hline M512 & 18 & $28.0 \pm 11.4$ & $14.1 \pm 9.6$ & 0.51 & $6.0 \pm 9.0$ & 0.22 & $3.2 \pm 10$ & 0.12 & $4.6 \pm 6.0$ & 0.17 \\
\hline
\end{tabular}

Table 11. Average percent ground cover plus or minus standard deviations for plot data by vegetation macrogroup.

$[\%$, percent; \pm , plus or minus; number of plots is 60$]$

\begin{tabular}{ccccc}
\hline $\begin{array}{c}\text { Vegetation } \\
\text { macrogroup } \\
\text { (see table 9) }\end{array}$ & $\begin{array}{c}\text { Litter } \\
(\%)\end{array}$ & $\begin{array}{c}\text { Rock } \\
(\%)\end{array}$ & $\begin{array}{c}\text { Basal stems } \\
(\%)\end{array}$ & $\begin{array}{c}\text { Biological } \\
\text { crusts } \\
(\%)\end{array}$ \\
\hline M086 & $28.6 \pm 12.1$ & $36.8 \pm 24.9$ & $0.6 \pm 0.9$ & $0 \pm 0$ \\
M087 & $46.3 \pm 18.8$ & $23.1 \pm 20.6$ & $1.9 \pm 2.8$ & $0 \pm 0$ \\
M512 & $31.7 \pm 11.6$ & $5.1 \pm 6.7$ & $0.8 \pm 0.1$ & $0 \pm 0$ \\
\hline
\end{tabular}

Table 12. Multiple linear regression equations and statistics for estimating total foliar cover, litter cover, and rock cover (from plot data) as a function of selected independent variables (from geospatial data corresponding to plot locations). ${ }^{1}$

$\left[F, F\right.$ statistic with degrees of freedom; $p$, probability value; $R^{2}$, coefficient of correlation; NDVI, normalized difference vegetation index; $<$, less than $]$

\begin{tabular}{|c|c|c|c|}
\hline Total foliar cover & $\boldsymbol{F}$ & $\boldsymbol{p}$ & $R^{2}$ \\
\hline Total foliar cover $=-54.81 * *+255.1 \mathrm{NDVI} * * *+0.043$ elevation $* *$ & $(2,57)=43$ & $<0.001$ & 0.605 \\
\hline \multicolumn{4}{|l|}{ Litter cover } \\
\hline Litter cover $=12.33 * * *+67.33$ total cover $* * *-0.336$ slope $*$ & $(2,57)=41$ & $<0.001$ & 0.592 \\
\hline \multicolumn{4}{|l|}{ Rock cover } \\
\hline Rock cover $=19.92 * * *-24.25$ total cover $*+141.8$ slope $^{* * *}$ & $(2,57)=57$ & $<0.001$ & 0.44 \\
\hline
\end{tabular}

${ }^{1}$ Significance level is shown for each coefficient: $p<0.05(*), p<0.01(* *), p<0.001(* * *)$.

\section{Scenario 2: Vegetation Sensitivity Analysis-20-Percent Increase in Vegetation Cover}

The second scenario assessed the sensitivity of Monument runoff and erosion to a 20-percent increase in vegetation cover over the baseline scenario. This scenario was formulated by increasing the percent aerial cover of all foliar groups (forbs, shrubs, bunch grass, or sod grass) from scenario 1 by 20 percent and recalculating the $K_{e}, K_{s s}$, and $F_{t}$ for each cell.

\section{Scenario 3: Vegetation Sensitivity Analysis-20-Percent Decrease in Vegetation Cover}

The third scenario assessed the sensitivity of Monument runoff and erosion to a 20-percent reduction in vegetation cover. This scenario was formulated by reducing the percent aerial cover of all foliar groups (forbs, shrubs, bunch grass, or sod grass) from Scenario 1 by 20 percent and recalculating $K_{e^{\prime}}$ $K_{s s}$, and $F_{t}$ for each cell.
Scenario 4: Drought, Heavy Grazing, or Land-Use Pressure

The fourth scenario assessed Monument response to severe drought or heavy grazing pressure. This scenario was formulated in the RHEM by decreasing the foliar cover of bunch grass, sod grass, and forbs by 40 percent while maintaining shrub foliar cover at its Scenario 1 value and recalculating $K_{e}, K_{s s}$, and $F_{t}$ for each cell.

\section{Scenario 5: Shrub Encroachment}

The fifth scenario assessed the transition of the Chihuahuan Desert from grassland to a shrub-dominated ecosystem. Shrub encroachment was simulated by maintaining total foliar cover at its Scenario 1 value, reducing all nonwoody foliar cover (bunch grass, sod grass, and forbs) by 40 percent, increasing the shrub cover proportionally, and recalculating $K_{e^{\prime}}$ $K_{s s}$, and $F_{t}$ for each cell. 


\section{Assessment of Soil and Water Resources}

By combining the existing soil- and water-resource data for the Monument and results of the methods as described, this section provides a basic assessment of the surface hydrological effects of selected alternatives to current (2016) land use and infrastructure.

\section{Assessment of Geology and Weathering Potential}

Physical and chemical weathering results indicate weathering potential variation across the Monument. Rock types and deposits that may be prone to physical weathering in the Monument are shown in figure 14. In contrast to figure 8, which shows all the formation names and deposits, figure 14 focuses on the general rock type or deposit that can indicate a potential for physical weathering.

Weathering resulting from frost or ice wedging is most likely to occur in the higher elevations, such as the Organ Mountains, because of changes in temperature at higher elevations. Once weathering occurs in mountains or mesas, erosion will begin, followed by deposition at lower elevations. Locations with higher elevation and slopes are described in the next section, Assessment of Landforms. The deposition of weathered sediments can ultimately form conglomerates and fanglomerates, which may be cemented and formed into a rock, but the degree of the cementation depends on several factors including time, pressure, and the type of cement holding the grains together. Within the Monument, conglomerates and fanglomerates are predominantly found in the Organ Mountains, Doña Ana Mountains, and Desert Peaks subunits (fig. 14).

The mafic igneous and basalt deposits, primarily located in the Potrillo subunit (fig. 14), are more susceptible to weathering by insolation because of their dark color than the felsic igneous and rhyolite deposits in the Desert Peaks, Organ Mountains, and Doña Ana Mountains subunits, which are lighter colored and reflect the sun more readily.

According to the CIW (Harnois, 1988), the higher the number, the higher the degree of chemical weathering a rock has undergone (table 13). Analysis of the EarthChem rock samples by using the CIW shows that the most weathered rocks are in and around the Organ Mountains subunit of the Monument and include silicic plutonic rocks and tuffs (fig. 15A). The CIA (Nesbitt and Young, 1982) designation of a sample increases as the weathering increases. Similar to results based on the CIW, most rocks designated as highly weathered based on the CIA are located in and around the Organ Mountains subunit, with a few weathered samples in the Potrillo subunit (fig. 15B). Conversely, for the WIP (Parker, 1970), the lower the WIP designation, the more weathered the rock. This index shows weathering in all the subunits of the Monument; however, the degree of weathering is not the same in all subunits (fig. 15C).

For the MWPI, the higher values indicate more leachable cations and easily broken-down crystal lattices (Reiche, 1943) (table 13). In the Monument, the rock types with the highest MWPI are tuffs; piedmont-slope deposits; lacustrine, fluvial, and alluvial sediments; and conglomerate facies (fig. 15D). The Vogt ratio (Roaldset, 1972) indicates that fresh (unweathered) rock has values less than 1 . This ratio indicates less weathering in the Potrillo Mountains than indicated by the other indices (fig. 15E). As shown by the other four indices, the more highly weathered samples are in the Organ Mountains subunit (fig. 15).

The results of this weathering evaluation indicate that areas with higher weathering potential or rocks more susceptible to weathering could provide increased sediment for erosion and the areas where erosion occurs may not have enough substrate to form soils. The chemical weathering data indicate that the Organ Mountains have the highest potential for weathering, which could affect erosion and deposition along the flanks of the mountains.

\section{Assessment of Landforms}

Eight landform maps were produced - four using the Hammond-Dikau method and four using the pattern-based Geomorphon method. Landform maps were created to better understand the relation between landforms, precipitation, and soils on erosion in the Monument area. The Hammond-Dikau method produced coarser landform maps than the patternbased Geomorphon method. Both methods were used to demonstrate differences between two different types of computed landform classifications. Landforms produced by the GRASS GIS Geomorphon method had only nine categories because of constraints in the script created by Jasiewicz and Stepinski (2012) that resulted in finding only the "most common" topographic features in a landscape. The Hammond-Dikau method, in comparison, produced many more landforms because the original authors used a broader definition of landforms. The landform categories for the Geomorphon method were related to a "well-known" landform definition or definitions for practical use (table 5). The landform map layers can be found in the geodatabase associated with this report (Mitchell and others, 2019).

The Desert Peaks subunit of the Monument has the most landforms of all the subunits (figs. 16, 17). The landscape is scattered with numerous arroyos, defined in figure 17 as depression/hollow or valley, including smaller arroyos that lead into the Placitas Arroyo. Flooding caused by runoff from the Placitas Arroyo is of major concern for the city of Placitas and Village of Hatch (fig. 1). The north-northwestern portion of the Desert Peaks subunit is dotted with peaks that make up the Sierra de las Uvas Mountains, and the southeastern portion of the subunit contains the Robledo Mountains. Between 


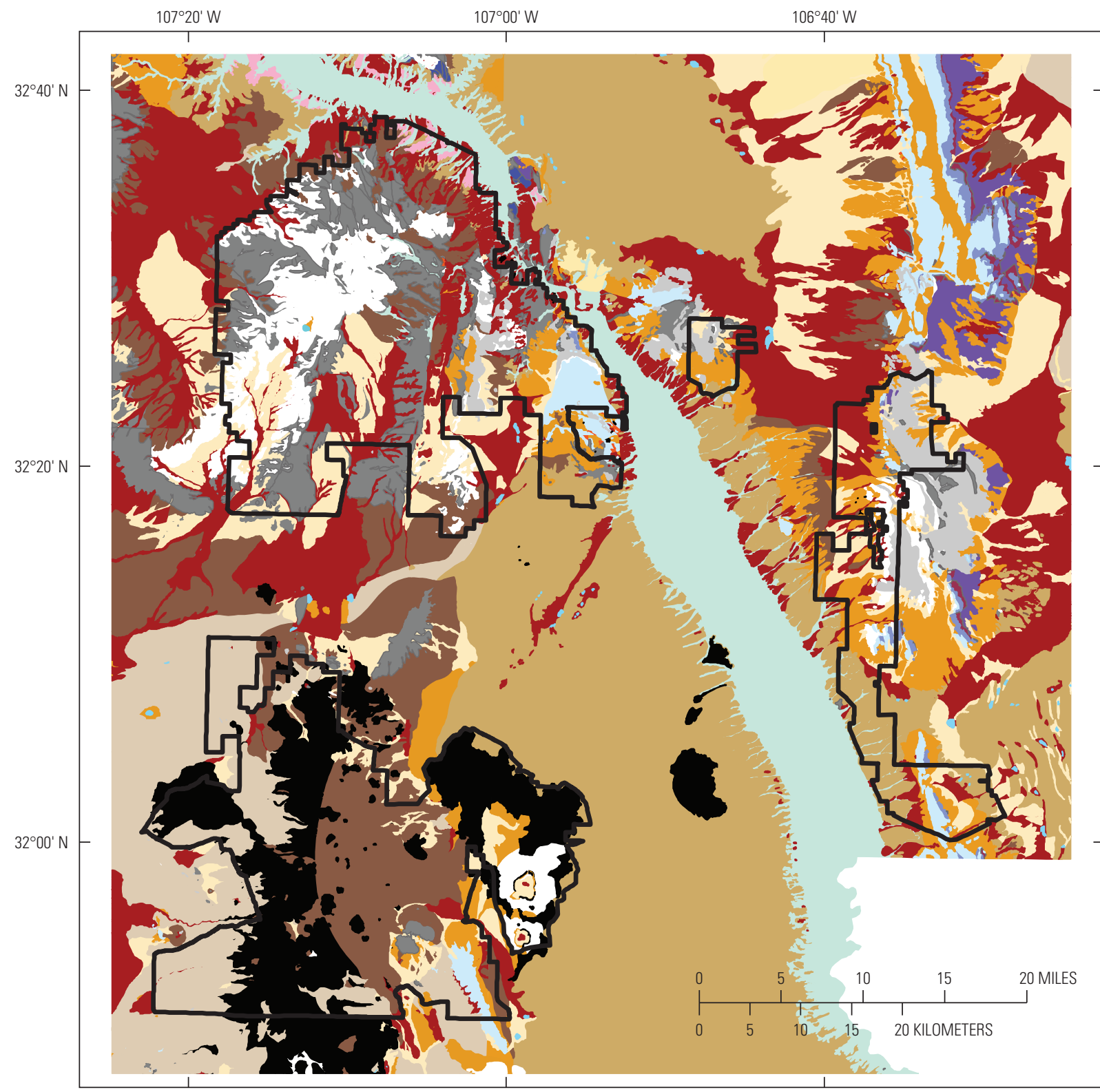

EXPLANATION
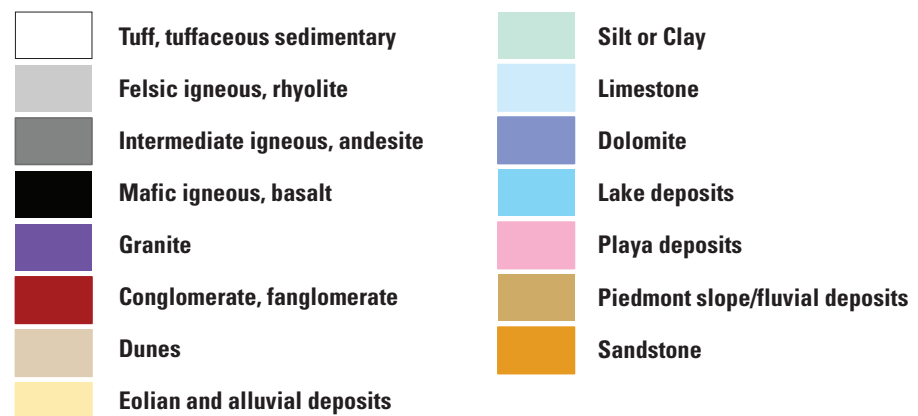

Figure 14. Surface geology by major rock type for qualitative understanding of physical weathering potential in the Organ Mountains-Desert Peaks National Monument, New Mexico (Seager and others, 1982, 1987; Seager, 1995). 
Table 13. Summary of weathering indices. Modified from Price and Velbel (2003).

$[\leq$, less than or equal to; >, greater than; $<$, less than; Al, aluminum; O, oxygen; Ca, calcium; $\mathrm{Na}$, sodium; Mg, magnesium; K, potassium; S, silicon; Fe, iron]

\begin{tabular}{|c|c|c|c|c|}
\hline Index & Formula & $\begin{array}{c}\text { Optimum } \\
\text { fresh } \\
\text { value }\end{array}$ & $\begin{array}{c}\text { Optimum } \\
\text { weathered } \\
\text { value }\end{array}$ & Reference \\
\hline $\begin{array}{l}\text { Chemical Index of Weath- } \\
\text { ering (CIW) }\end{array}$ & {$\left[\mathrm{Al}_{2} \mathrm{O}_{3} /\left(\mathrm{Al}_{2} \mathrm{O}_{3}+\mathrm{CaO}+\mathrm{Na}_{2} \mathrm{O}\right)\right] \times 100$} & $\leq 50$ & 100 & Harnois (1988) \\
\hline $\begin{array}{l}\text { Chemical Index of Altera- } \\
\text { tion (CIA) }\end{array}$ & {$\left[\mathrm{Al}_{2} \mathrm{O}_{3} /\left(\mathrm{Al}_{2} \mathrm{O}_{3}+\mathrm{CaO}+\mathrm{Na}_{2} \mathrm{O}+\mathrm{K}_{2} \mathrm{O}\right)\right] \times 100$} & $\leq 50$ & 100 & Nesbitt and Young (1982) \\
\hline $\begin{array}{l}\text { Modified Weathering Po- } \\
\text { tential Index (MWPI) }\end{array}$ & $\begin{array}{l}{\left[\left(\mathrm{Na}_{2} \mathrm{O}+\mathrm{K}_{2} \mathrm{O}+\mathrm{CaO}+\mathrm{MgO}\right) /\left(\mathrm{Na}_{2} \mathrm{O}+\mathrm{K}_{2} \mathrm{O}+\mathrm{CaO}+\right.\right.} \\
\left.\left.\quad \mathrm{MgO}+\mathrm{SiO}_{2}+\mathrm{Al}_{2} \mathrm{O}_{3}+\mathrm{Fe}_{2} \mathrm{O}_{3}\right)\right] \times 100\end{array}$ & 0 & 100 & $\begin{array}{l}\text { Reiche (1943), modified } \\
\text { by Vogel (1975) }\end{array}$ \\
\hline Vogt ratio $(\mathrm{V})$ & $\left(\mathrm{Al}_{2} \mathrm{O}_{3}+\mathrm{K}_{2} \mathrm{O}\right) /\left(\mathrm{MgO}+\mathrm{CaO}+\mathrm{Na}_{2} \mathrm{O}\right)$ & $<1$ & Infinite & Roaldset (1972) \\
\hline
\end{tabular}

many of the peaks and hills in the mountain ranges lie valleys, canyons, and flatlands.

The rugged terrain in the northwestern portion of the Desert Peaks subunit may directly relate to the limited detailed availability of soil data in this area. The steeper slopes and canyons in this subunit may affect accessibility to the area for accurate collection of soil sample data as well as production of reliable water capacity and infiltration information. Additionally, because of the steeper slopes, weathered rock would tend to erode and deposit at a lower elevation in the subunit, decreasing the potential for soils to form at higher elevations (Birkeland, 1999).

The Doña Ana subunit contains less variation in landform type compared to the Desert Peaks subunit. The Doña Ana subunit consists of valleys, depressions, and ridges, as well as many slopes, most likely hillslopes, radiating out from the center of the subunit (figs. 18, 19). The subunit is the smallest of the four subunits of the Monument and does not have any major roads or campgrounds within its landscape, although there is a set of recreational trails in the southern portion of the subunit (fig. 11).

While the Doña Ana subunit does have gentle enough (0-3 percent) slopes to support grazing (Emenkie and others, 2016), the lack of watering troughs indicates a lack of sufficient edible vegetation to support grazing (fig. 13). Vegetation on the slopes of the subunit is Chihuahuan Desert Scrub (M086), and the steeper area in the northern portion of the unit is populated with a Warm Semi-Desert Cliff, Scree and Rock Vegetation (M117) (fig. 3).

The Organ Mountains subunit has the steepest slopes of the four Monument subunits and is characterized by its jagged peaks (figs. 20, 21). There are fewer valleys than in the Desert Peaks and Doña Ana subunits, but a few major arroyos flow from the peaks into the valley to the west. The steep slope faces influence infiltration rates and potential vegetative cover and weathering. The Organ Mountains subunit is dominated primarily by slopes, ridges, and hollows. The hiking trails and camping areas that are abundant within this subunit could be affected by erosion along the step sections (fig. 12). This subunit of the Monument has the densest vegetative cover, ranging from 20 to 80 percent, which may result from its proximity to the Rio Grande, as well as desert storms that may form and become trapped in the subunit's steep peaks.

The Potrillo Mountains subunit is dominated by the West Potrillo Mountains and East Potrillo Mountains. Several valleys are within the Portillo Mountains subunit, and minor slopes radiate from the center of the subunit (figs. 22, 23). The central area of the subunit has plains and tablelands (fig. 22). The subunit is relatively flat so issues with erosion are likely small.

\section{Assessment of Infiltration Potential Across the Landscape}

The IPI results ranged from 10.6 to 91.6 (unitless) and were split into four infiltration potential categories: low (less than 25), moderate low (25-50), moderate high (50-75), and high (greater than 75). These results should be considered qualitative despite having been assigned numeric values and are not a direct measure of infiltration or runoff, meaning that exact infiltration rates (such as inches per hour) were not determined. Less than 1 percent of the Monument area was rated as having a low infiltration potential, 70 percent of the area had a moderate low infiltration potential, 29 percent had a moderate high infiltration potential, and less than 1 percent had a high infiltration potential (fig. 24). 


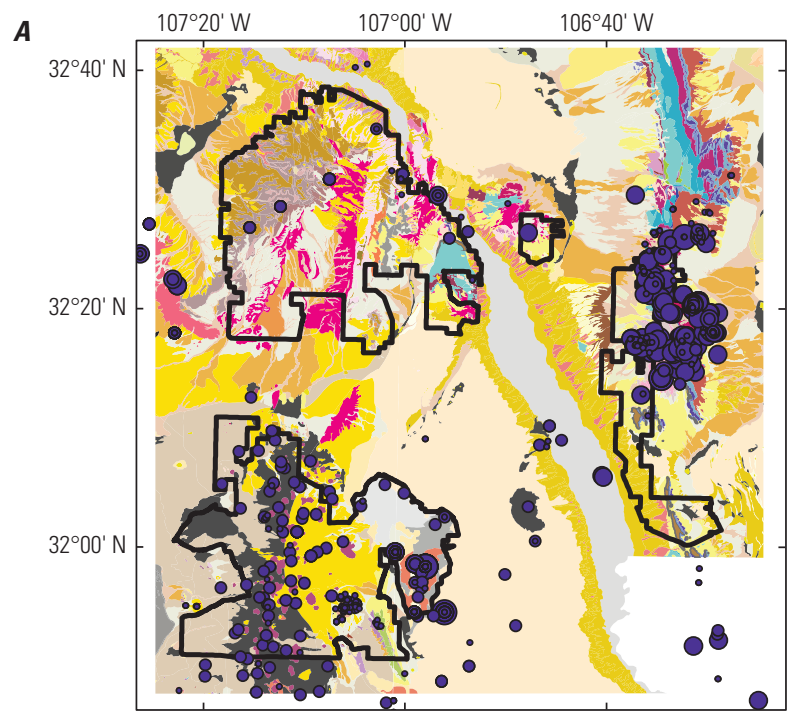

Chemical Index of Weathering (CIW)

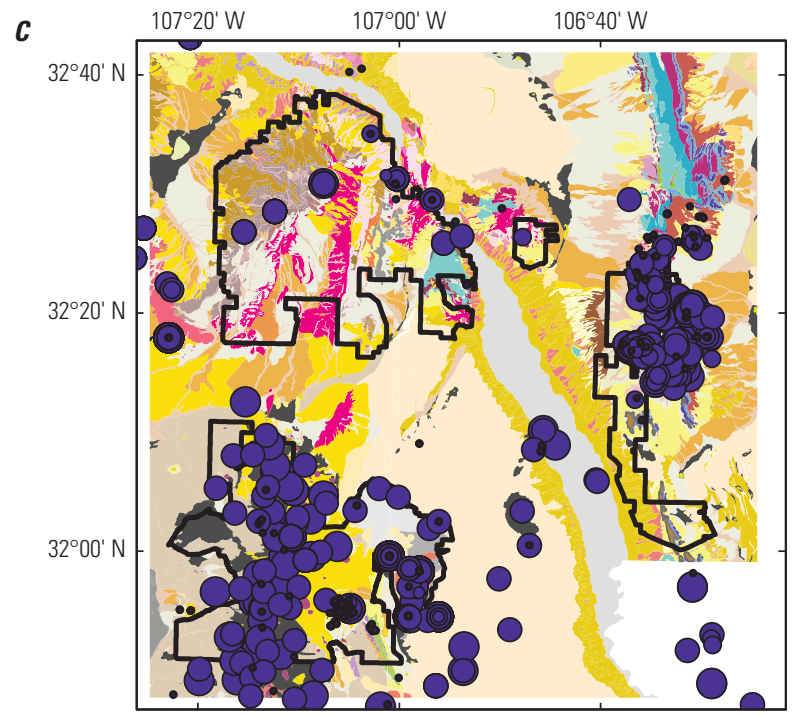

Weathering Index of Parker (WIP)

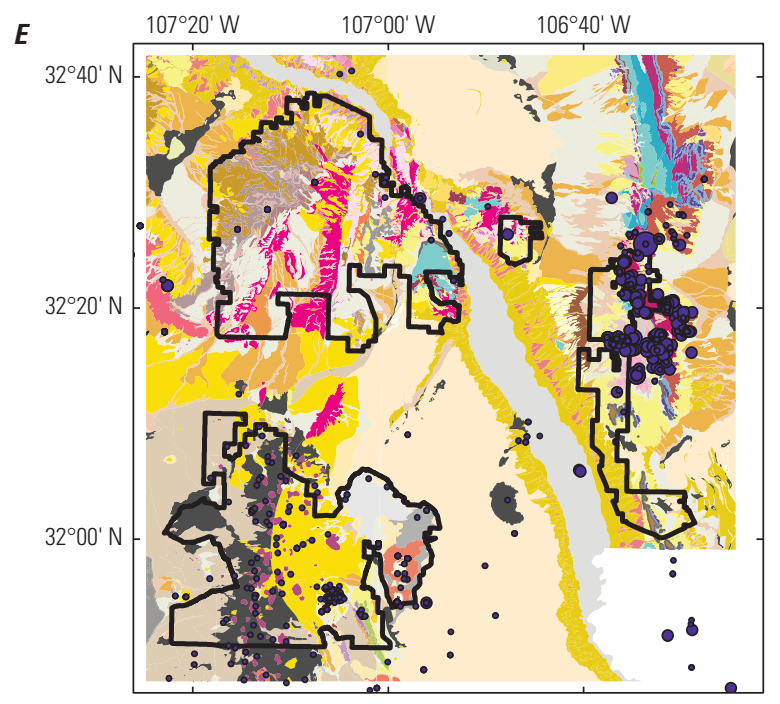

Vogt Ratio (V)

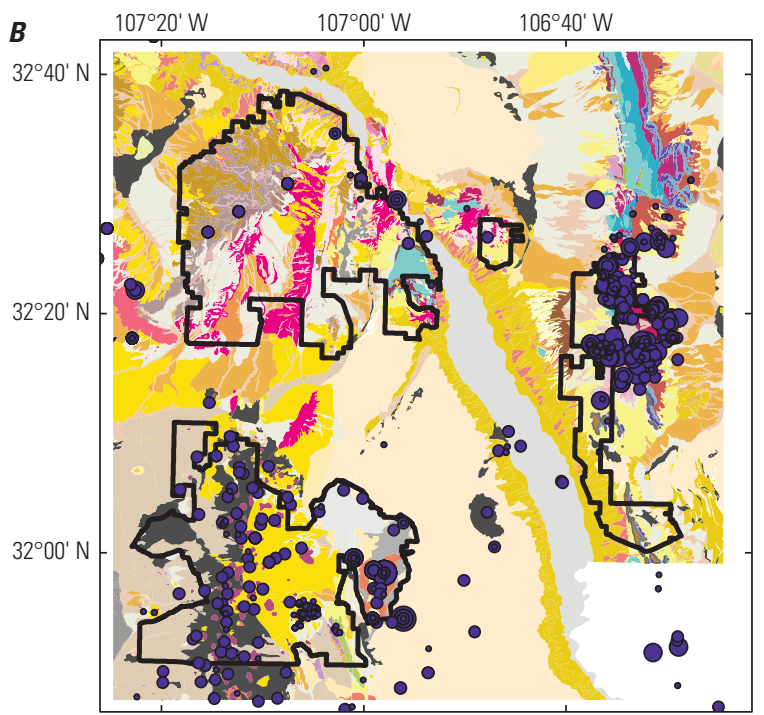

Chemical Index of Alteration (CIA)

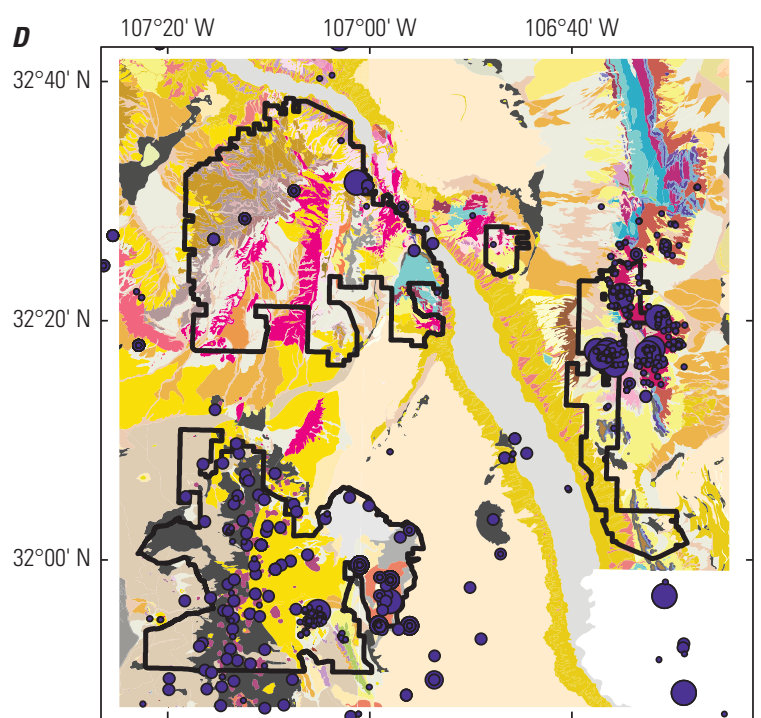

Modified Weathering Potential Index (MWPI)

EXPLANATION

CIW, CIA, MWPI
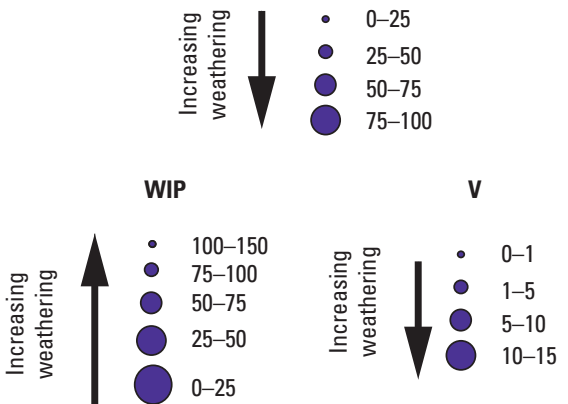

Figure 15. Distribution of potential for rock weathering in the Organ Mountains-Desert Peaks National Monument, New Mexico, based on five chemical weathering indices. 


\section{EXPLANATION}

Quaternary

Fluvial-facies

Fluvial-facies

Piedmont-slope facies

Arroyo-channel, fan, deposits

Fan and terrace deposits

Basin sediments

Camp Rice Formation transitional deposits

Lake Deposits

Alluvial deposits

Closed-basin deposits

Basin-floor deposits

Eolian sand dunes

Flood-plain and channel deposits

Playa deposit

Ancestral Rio Grande drainage
Quaternary (continued)

Modern drainageway deposits

Piedmont-slope facies

River, arroyo, fan deposits

Tuff and breccia

Basalt of West Potrillo Mountains

Olivine basalt

Afton Basalt

Aden Basalt

Tertiary

Tuffs and epiclastic rocks

Uvas Basaltic Andesite

Member of Uvas Basaltic Andesite

Silicic plutonic intrusions

Andesite-latite flows

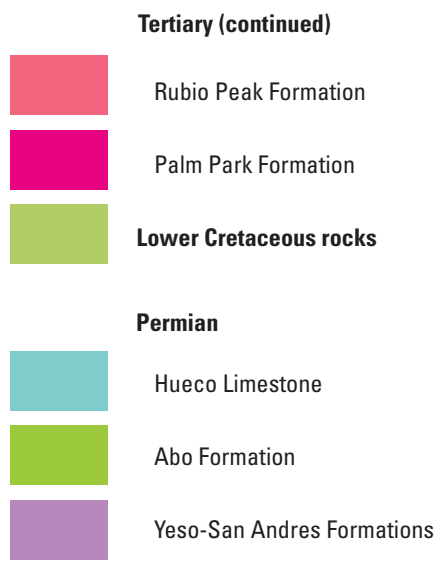

Pennsylvanian

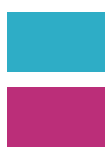

Panther Seep Formation

Lead Camp Limestone

Cambrian to Silurian

Dolomite

Precambrian granite

Organ Mountains-Desert Peaks National Monument and subunit boundaries

Figure 15. Distribution of potential for rock weathering in the Organ Mountains-Desert Peaks National Monument, New Mexico, based on five chemical weathering indices.-Continued 


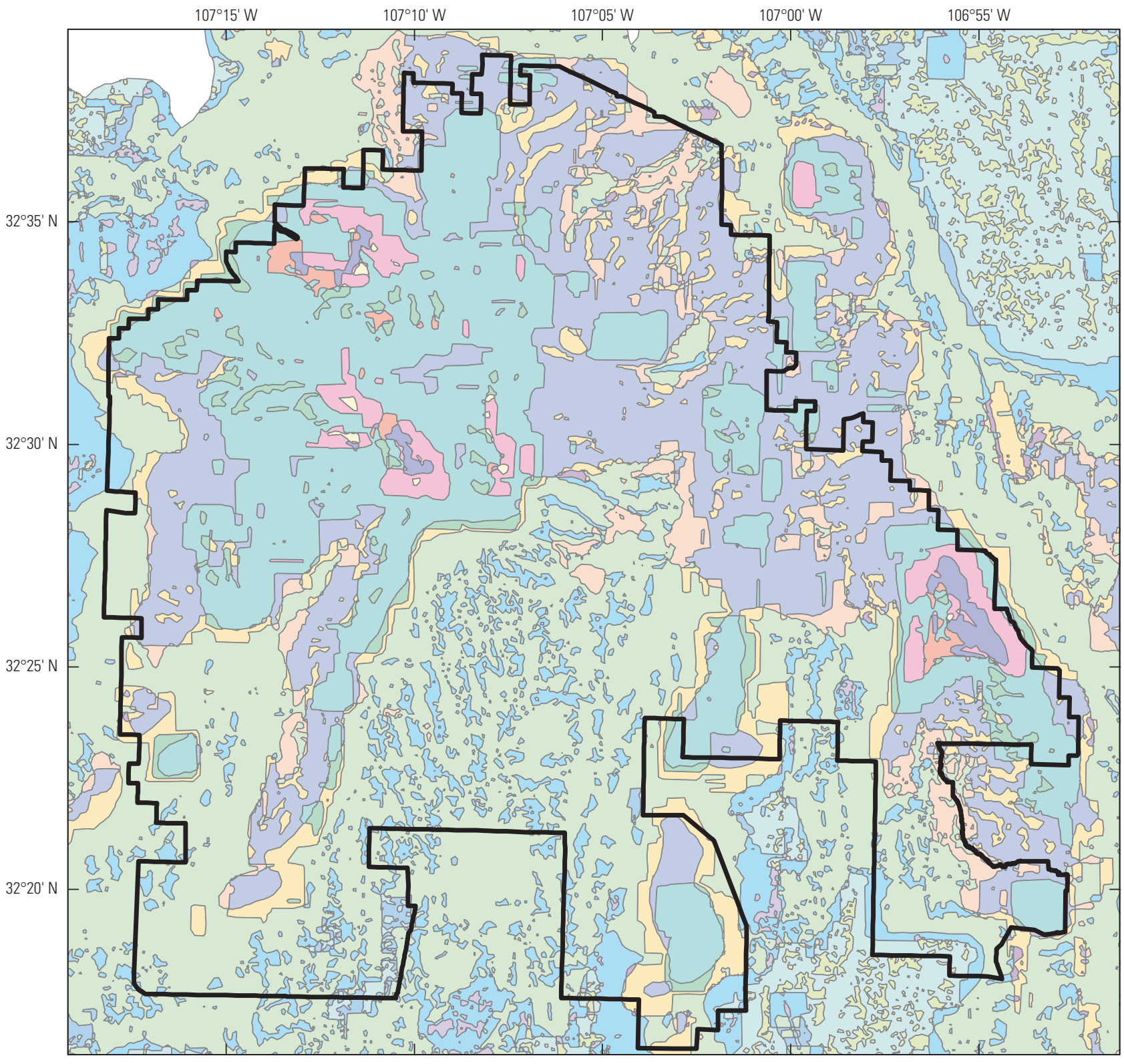

Bases from U.S. Census Bureau county shapefiles,

The National Map 30-meter Digital Elevation Model,

Universal Transverse Mercator Zone 13 projection,

North American Datum of 1983

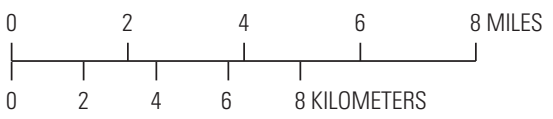

EXPLANATION

\begin{tabular}{|c|}
\hline \multirow{2}{*}{$\begin{array}{l}\text { Flat or nearly flat plains } \\
\text { High hills }\end{array}$} \\
\hline \\
\hline Irregular plains with low relief \\
\hline Low hills \\
\hline Low mountains \\
\hline Moderate hills \\
\hline Open high hills \\
\hline
\end{tabular}
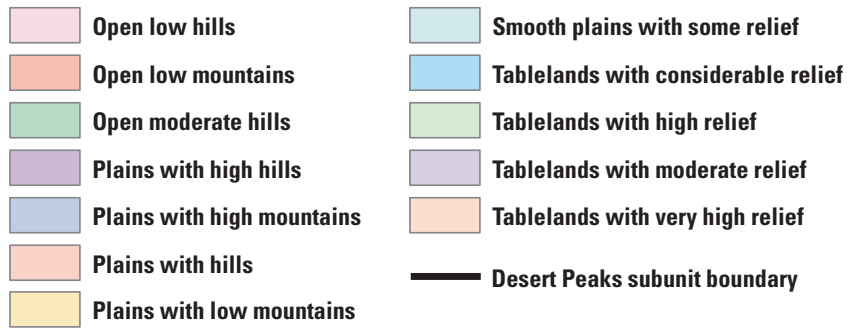

Figure 16. Hammond-Dikau method landforms map, Desert Peaks subunit, Organ Mountains-Desert Peaks National Monument, New Mexico. 
$107^{\circ} 12^{\prime} \mathrm{W}$

$107^{\circ} 04^{\prime} \mathrm{W}$

$106^{\circ} 56^{\prime} \mathrm{W}$

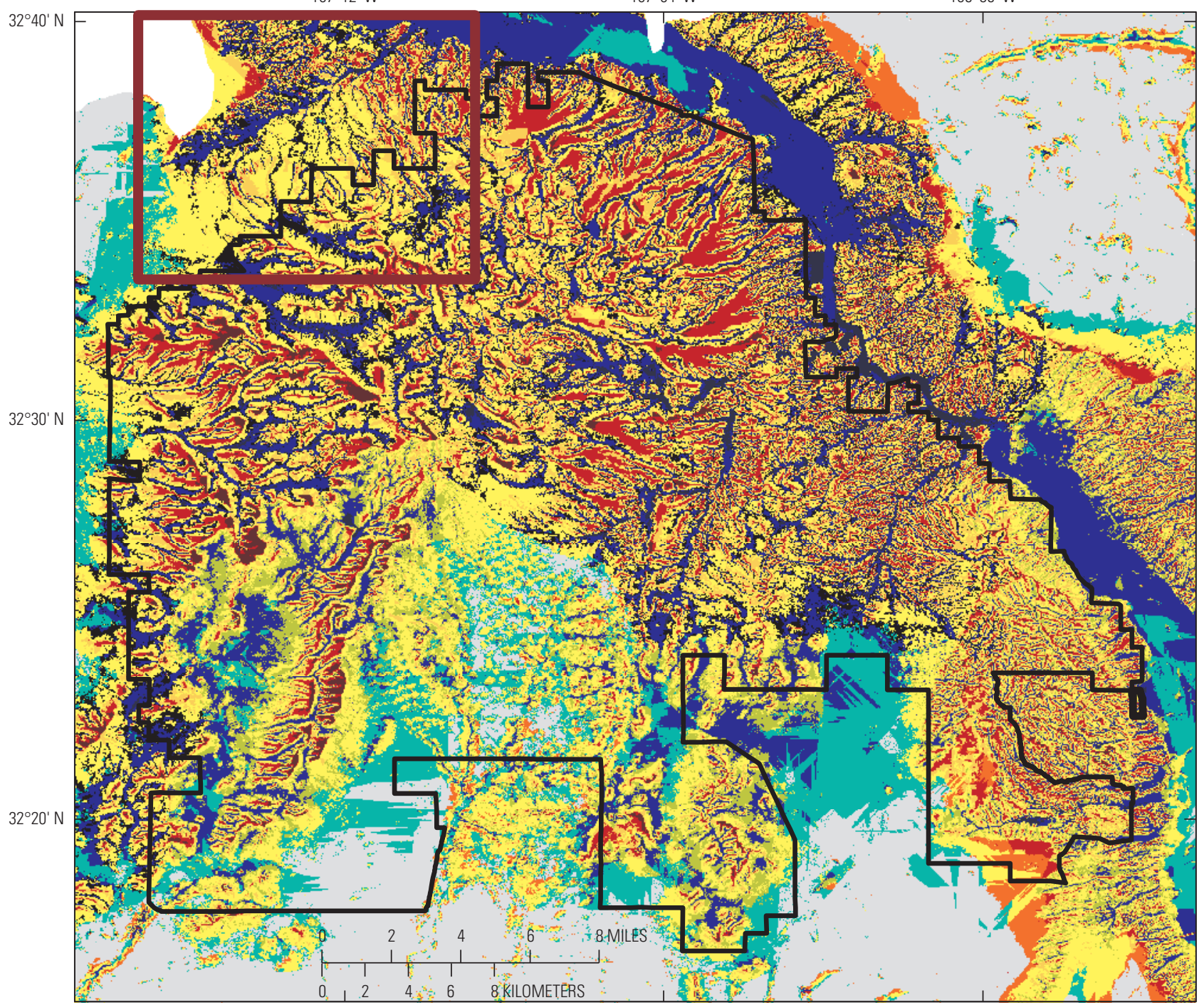

Bases by The National Map 10-meter Digital Elevation Model (DEM), Universal Transverse Mercator Zone 13 projection, North American Datum of 1983

\section{EXPLANATION}

\begin{tabular}{|l|l|}
\hline Depression/Hollow & Spur \\
\hline Flat & Slope \\
\hline Summit & Footslope \\
\hline Ridge & Valley \\
\hline Shoulder & \\
\hline
\end{tabular}

Figure 17. Geomorphon method landforms map, Desert Peaks subunit, Organ Mountains-Desert Peaks National Monument, New Mexico.

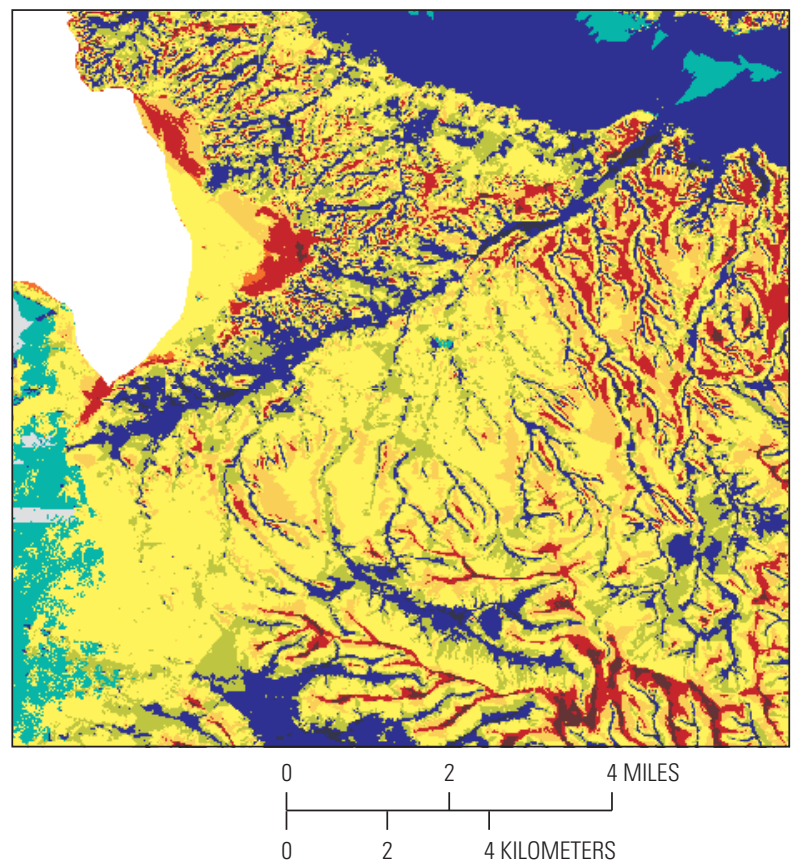




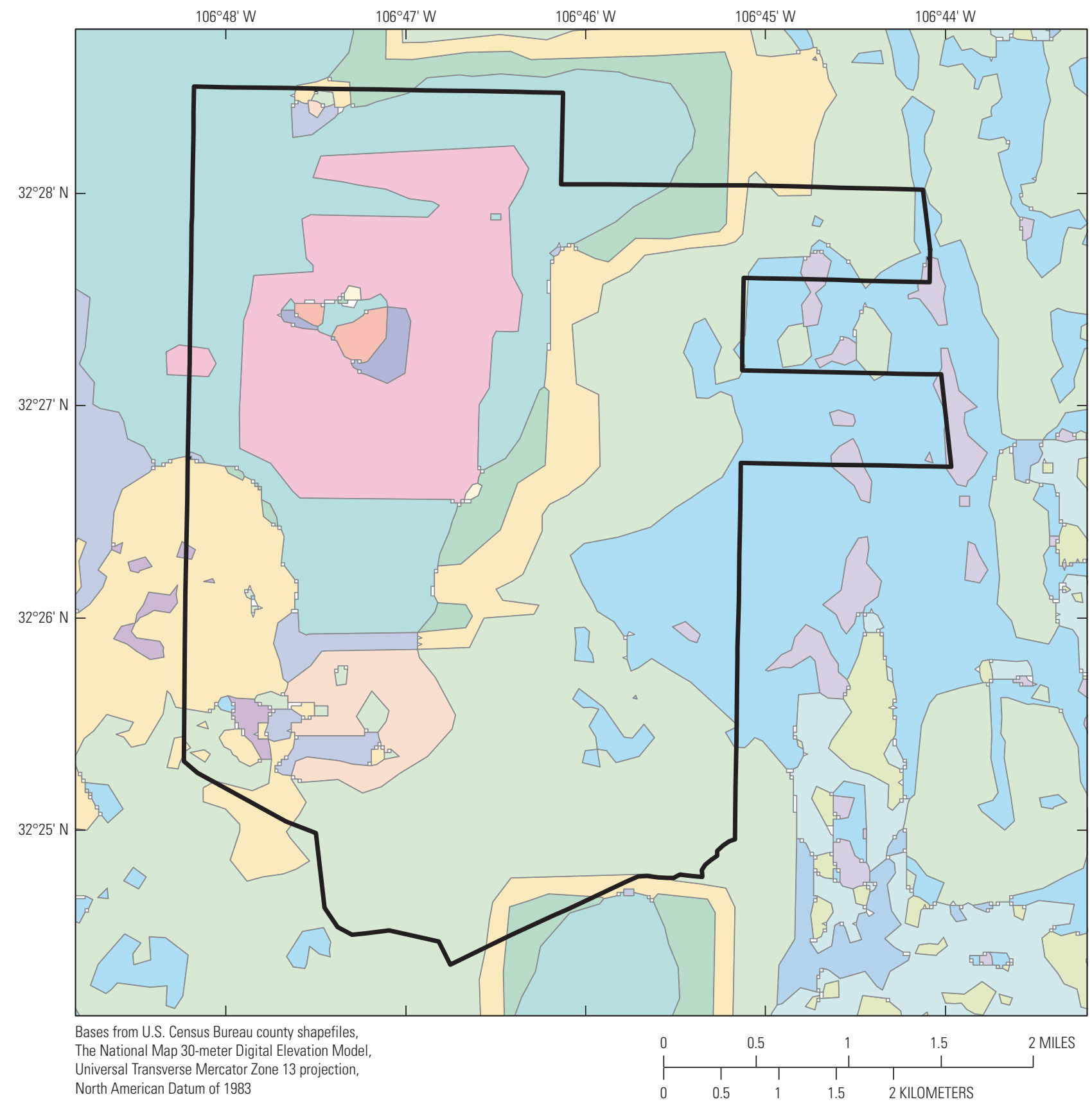

EXPLANATION

\begin{tabular}{|c|c|}
\hline Flat or nearly flat plains & Open low hills \\
\hline High hills & Open low mountains \\
\hline Irregular plains with low relief & Open moderate hills \\
\hline Low hills & Plains with high hills \\
\hline Low mountains & Plains with high mountains \\
\hline Moderate hills & Plains with hills \\
\hline Open high hills & Plains with low mountains \\
\hline
\end{tabular}

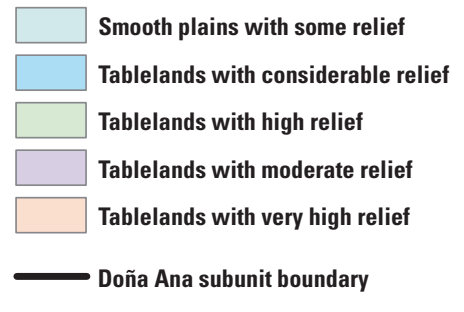

Figure 18. Hammond-Dikau method landforms map, Doña Ana subunit, Organ Mountains-Desert Peaks National Monument, New Mexico. 


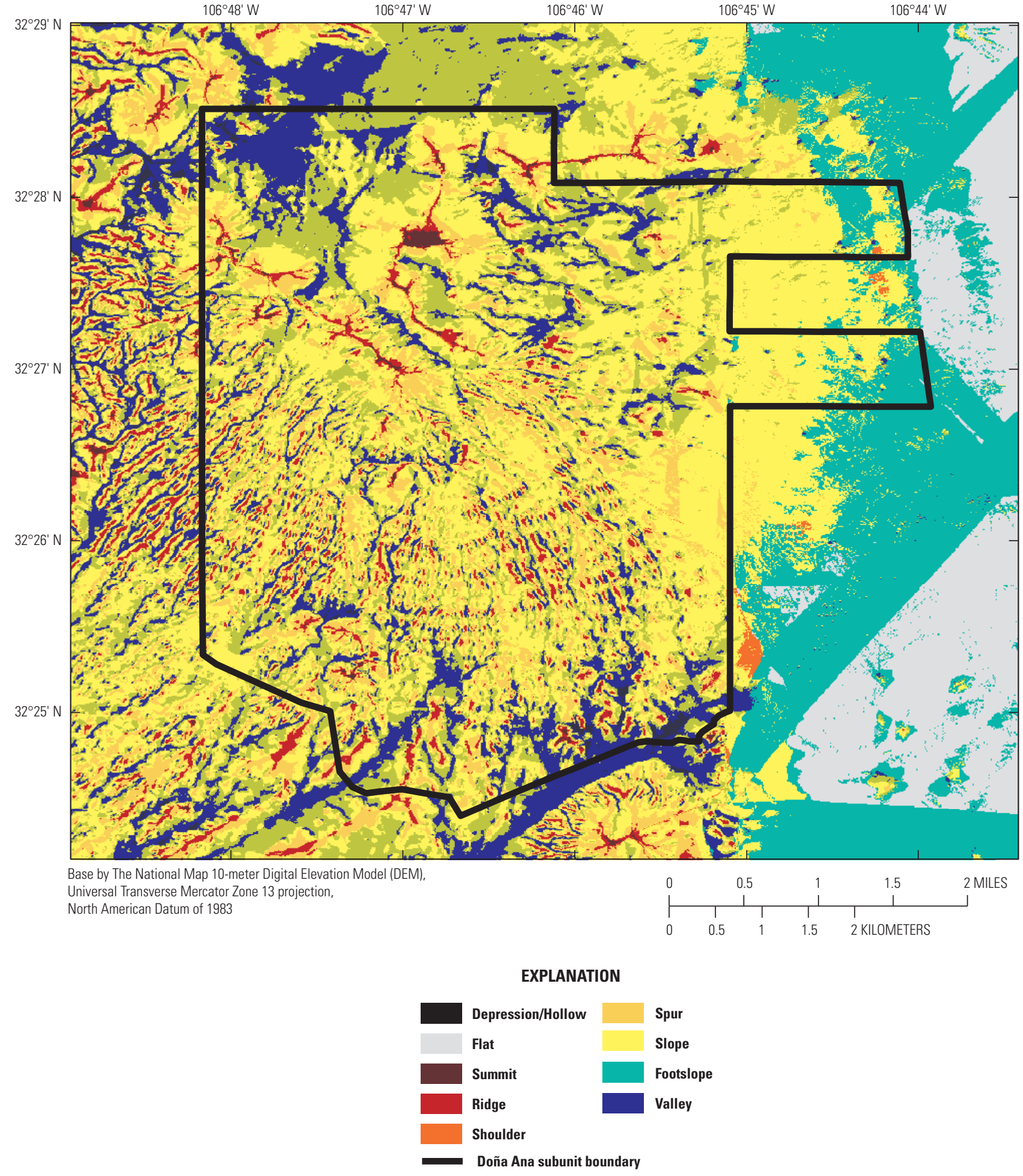

Figure 19. Geomorphon method landforms map, Doña Ana subunit, Organ Mountains-Desert Peaks National Monument, New Mexico. 


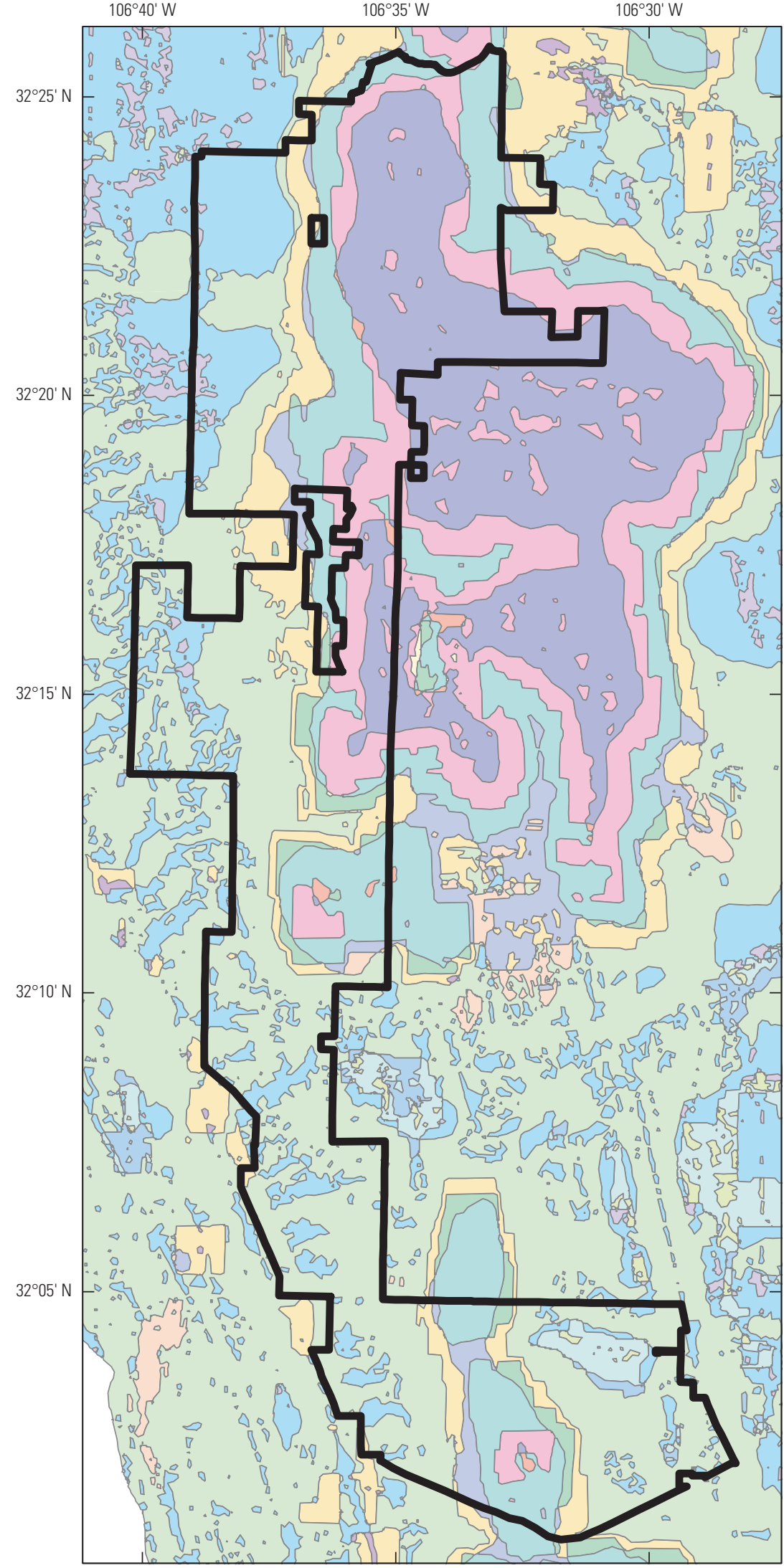

\section{EXPLANATION}
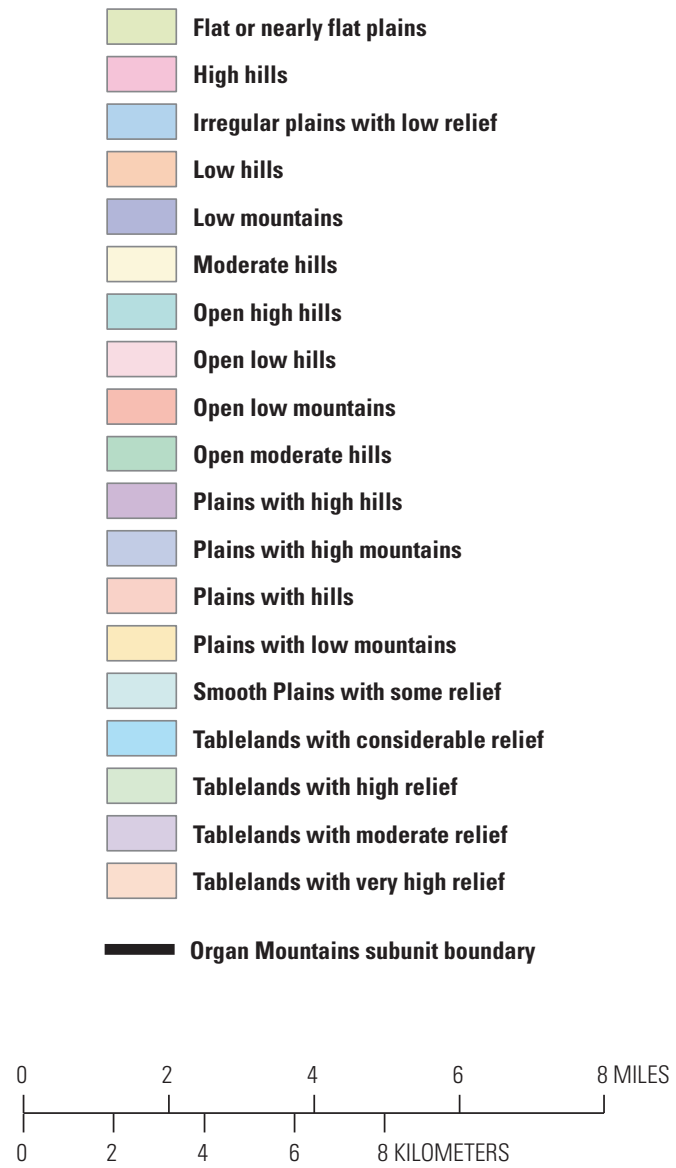

Bases from U.S. Census Bureau county shapefiles, The National Map 30-meter Digital Elevation Model, Universal Transverse Mercator Zone 13 projection, North American Datum of 1983

Figure 20. Hammond-Dikau method landforms map, Organ Mountains subunit, Organ Mountains-Desert Peaks National Monument, New Mexico. 




\section{EXPLANATION}
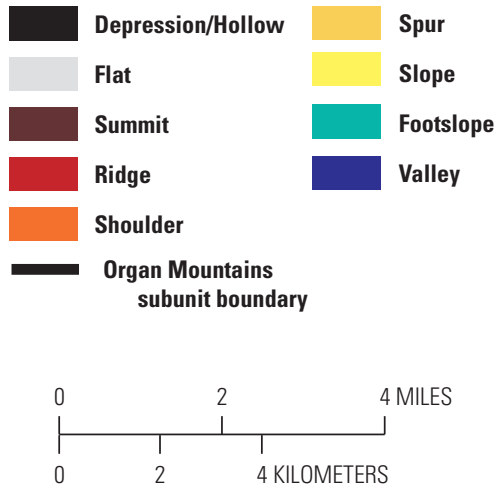

Bases by The National Map

10-meter Digital Elevation Model (DEM).

Universal Transverse Mercator Zone 13 projection, North American Datum of 1983

Figure 21. Geomorphon method landforms map, Organ Mountains subunit, Organ Mountains-Desert Peaks National Monument, New Mexico. 


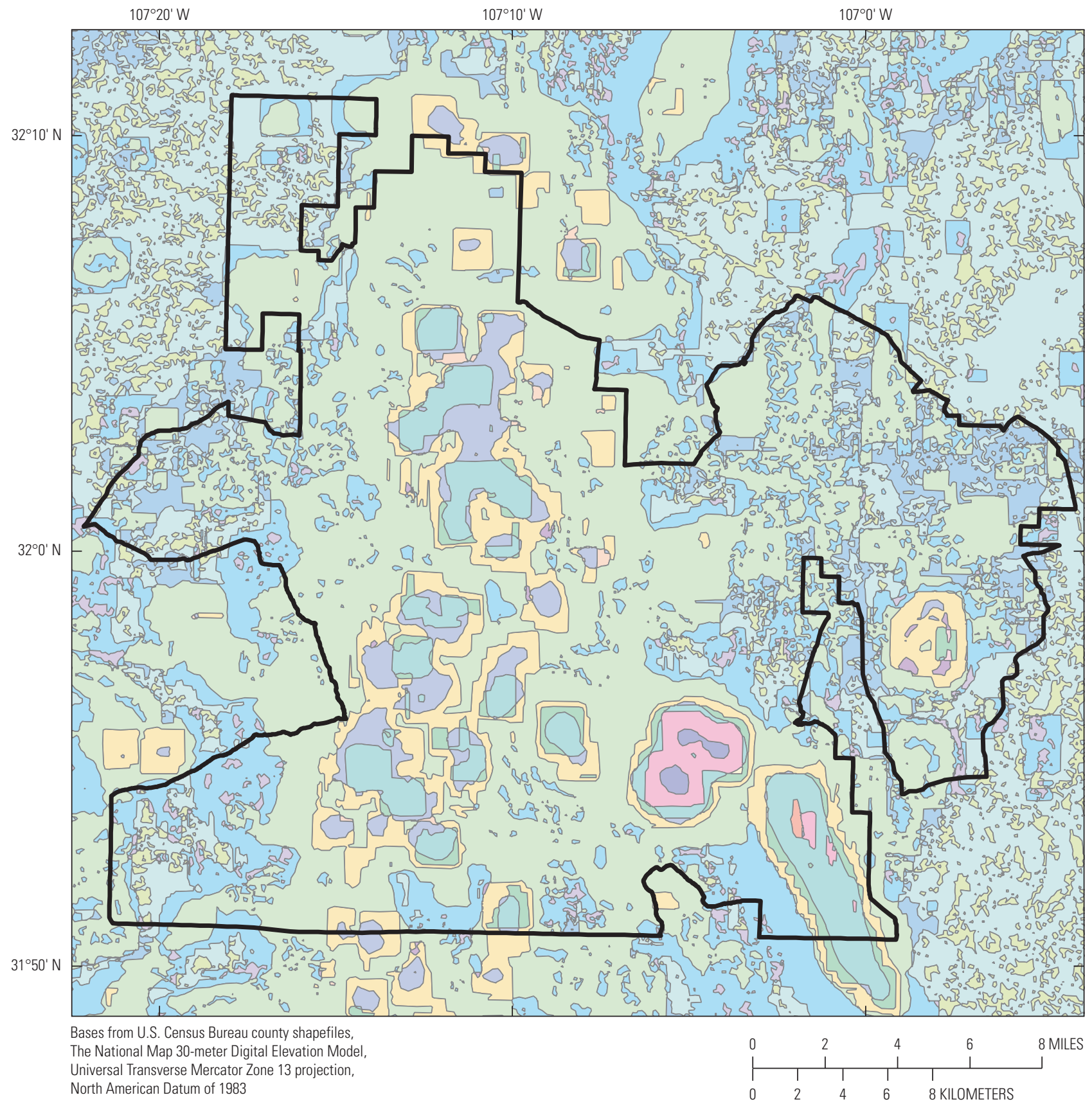

North American Datum of 1983

\section{EXPLANATION}

\begin{tabular}{|c|}
\hline Flat or nearly flat plains \\
\hline High hills \\
\hline Irregular plains with low relief \\
\hline Low hills \\
\hline Low mountains \\
\hline Moderate hills \\
\hline Open high hills \\
\hline
\end{tabular}

Plains with hills
Open low hills

Open low mountains

Open moderate hills

Plains with high hills

Plains with high mountains

Plains with low mountains

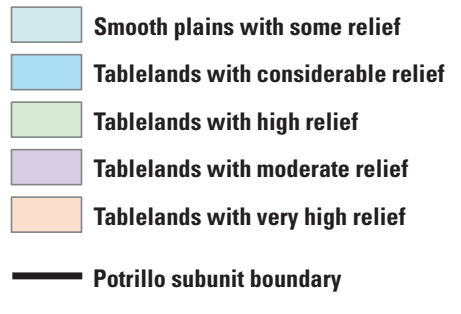

Figure 22. Hammond-Dikau method landforms map, Potrillo subunit, Organ Mountains-Desert Peaks National Monument, New Mexico. 


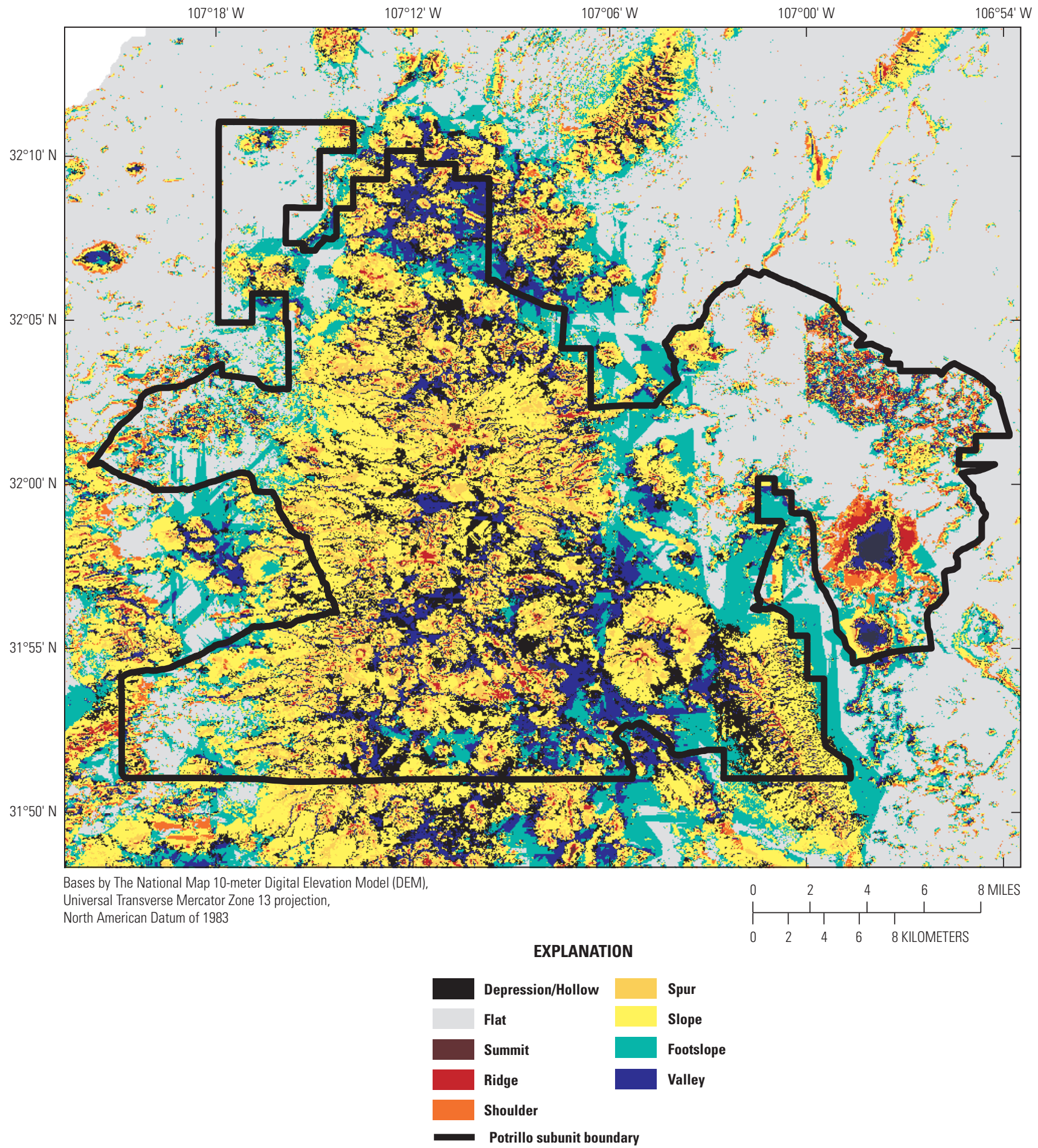

Figure 23. Geomorphon method landforms map, Potrillo subunit, Organ Mountains-Desert Peaks National Monument. 


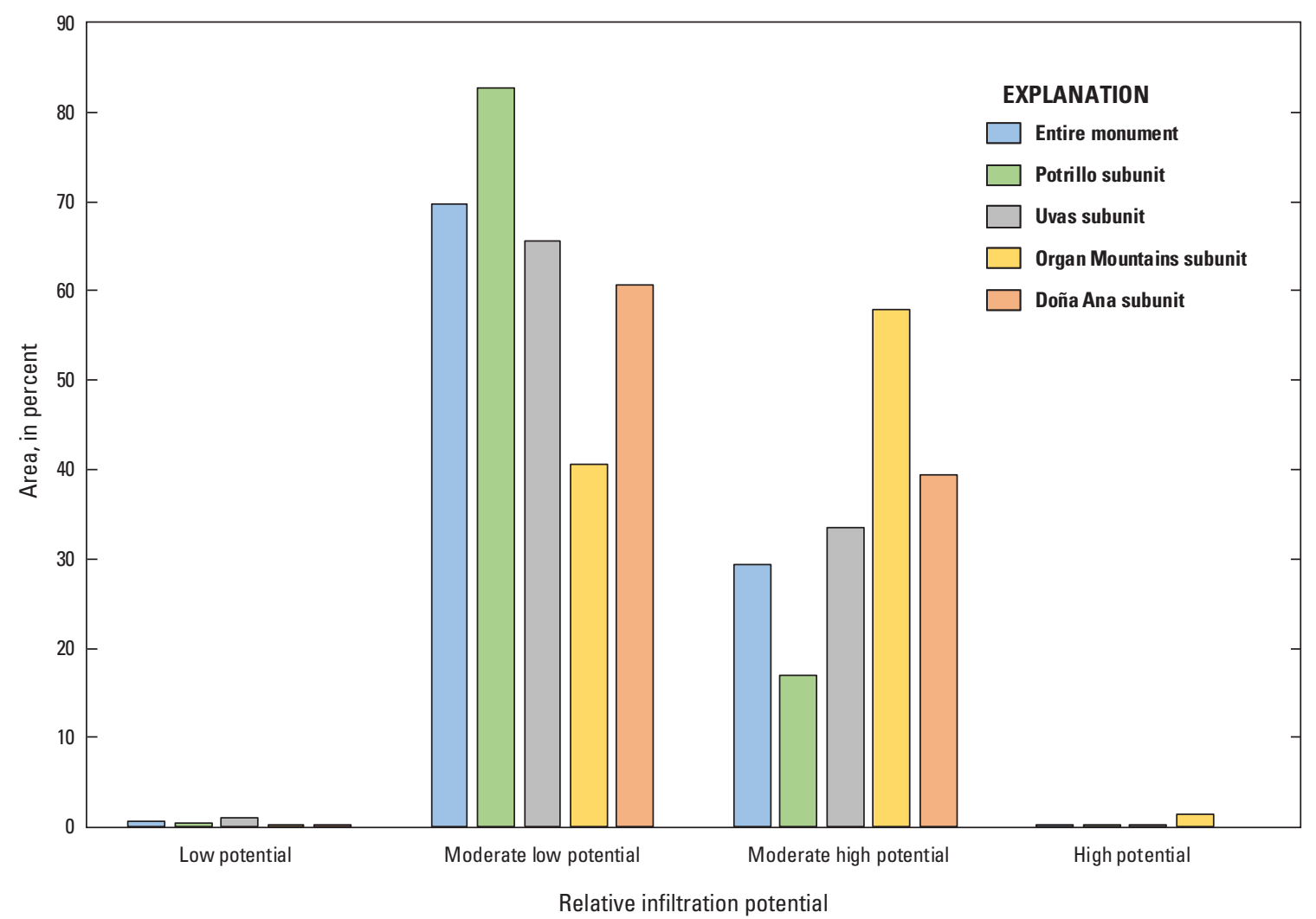

Figure 24. Infiltration potentials for individual subunits and for the entire Organ Mountains-Desert Peaks National Monument, New Mexico.

\section{Assessment of Runoff and Erosion Across the Landscape-RHEM Results}

RHEM results for each scenario are presented in the following sections. The model reports runoff (in inches per year) and soil loss (in tons per acre year) for each cell within the Monument. Annual average runoff for the baseline conditions (Scenario 1) varied considerably across the Monument, from 0.1 to $3 \mathrm{in} / \mathrm{yr}$ ( 3 to $76 \mathrm{~mm} / \mathrm{yr}$ ), in response to the varied topography, soil, and ground cover data. As expected, soil texture (fig. 5) was a determinant of runoff magnitude, with the lowest values of annual average runoff consistently estimated for areas of the Monument with sand soils and the highest values consistently estimated for areas with clay soils (fig. 25A). A portion of the variability of annual average runoff within soil types was related to total foliar cover (figs. 4 and 25B). Simulated annual average runoff generally decreased linearly with increasing foliar cover. Lower runoff sand and loamy sand soils demonstrated less response to foliar cover than higher runoff clay and sandy loam soils.

Simulated annual average soil loss for the baseline conditions (Scenario 1) at the cell scale varied from 0 to 2.75 tons per acre per year ([tons/acre]/yr) in response to the varied topography, soil, and ground cover data in the Monument. Simulated soil loss tended to increase linearly with an increase in slope, but with considerable variability (coefficient of determination $\left[R^{2}\right]=0.25$, fig. $26 A$ ). A portion of the variability of annual soil loss was related to soil texture (fig. 26B). Soil loss was lowest for sand and clay soils and highest for silty clay loam soils. The relative magnitude and variability of simulated soil loss between the different soil texture categories (fig. 26B) was similar to the relative magnitude and variability of slope among the different soil texture categories (fig. 26C).

Annual average soil loss across the Monument for the baseline scenario (Scenario 1) was 0.37 (ton/acre)/yr (figs. 27 and 28, table 14). Among the three simulated vegetation macrogroups, the North American Warm Desert Ruderal Scrub and Grassland (M512) had the lowest rate of annual average soil loss at 0.14 (ton/acre)/yr, followed by the Chihuahuan SemiDesert Grassland (M087) at 0.38 (ton/acre)/yr. The Chihuahuan Desert Scrub (M086) macrogroup had the highest annual average soil loss at 0.45 (ton/acre)/yr (table 14). This pattern of individual vegetation macrogroup soil-loss rates carries throughout all scenarios but with commensurate increases or decreases in soil loss depending on scenario conditions. 

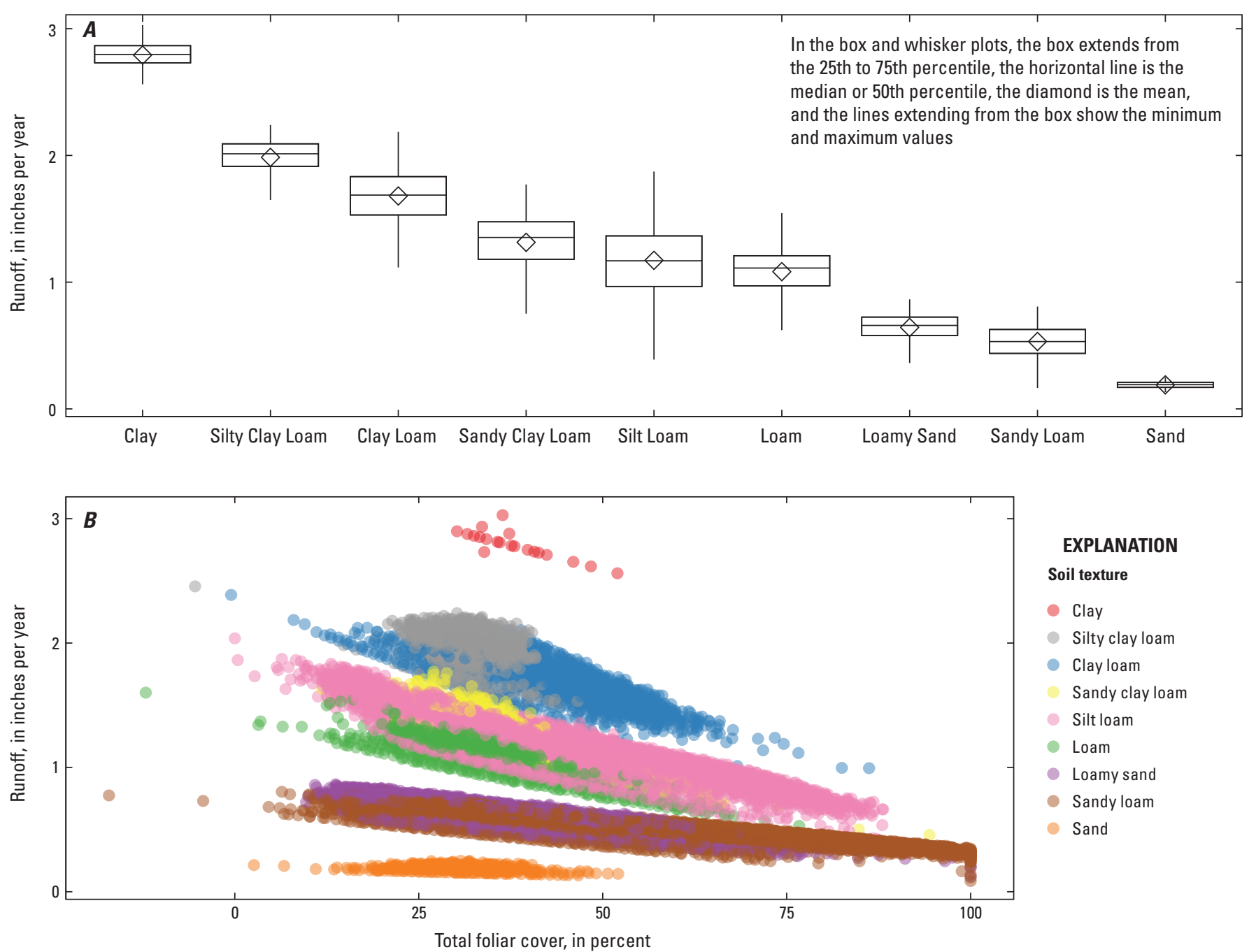

EXPLANATION

Soil texture

- Clay

- Silty clay loam

- Clay loam

Sandy clay loam

- Silt loam

- Loam

- Loamy sand

- Sandy loam

- Sand

Figure 25. RHEM-simulated annual average runoff response to $(A)$ soil texture and $(B)$ total foliar cover and soil texture for 168,276 cells in the Organ Mountains-Desert Peaks National Monument, New Mexico. 

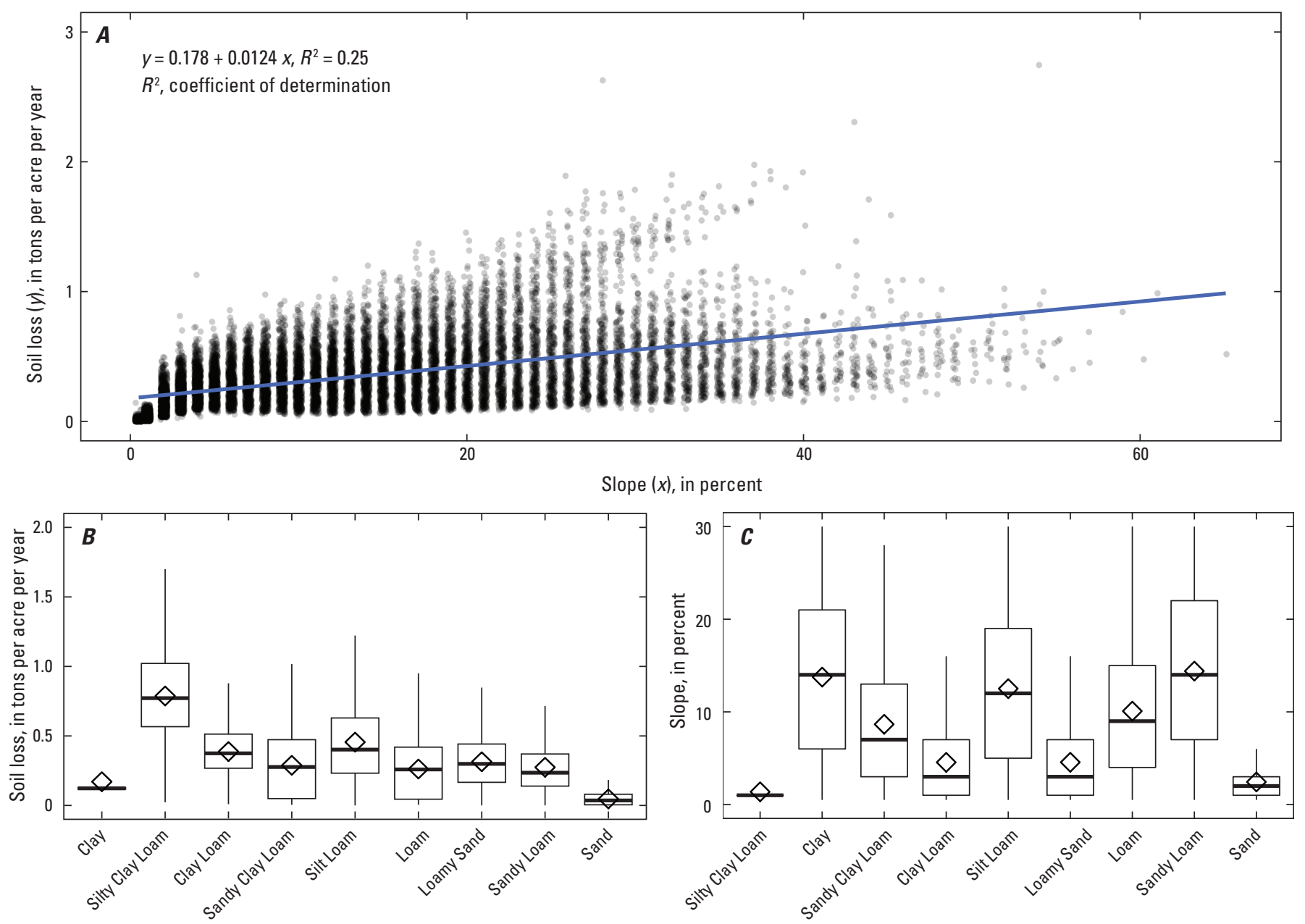

Box and whisker plots are shown in $B$ and $C$. The box extends from the 25th to 75 th percentile, the horizontal line is the median or 50th percentile, the diamond is the mean, and the lines extending from the box show the minimum and maximum values

Figure 26. Rangeland Hydrology and Erosion Model (RHEM)-simulated annual average soil loss response to $(A)$ slope and $(B)$ soil texture and $(C)$ relation between slope and soil texture for 168,276 cells in the Organ Mountains-Desert Peaks National Monument, New Mexico. 


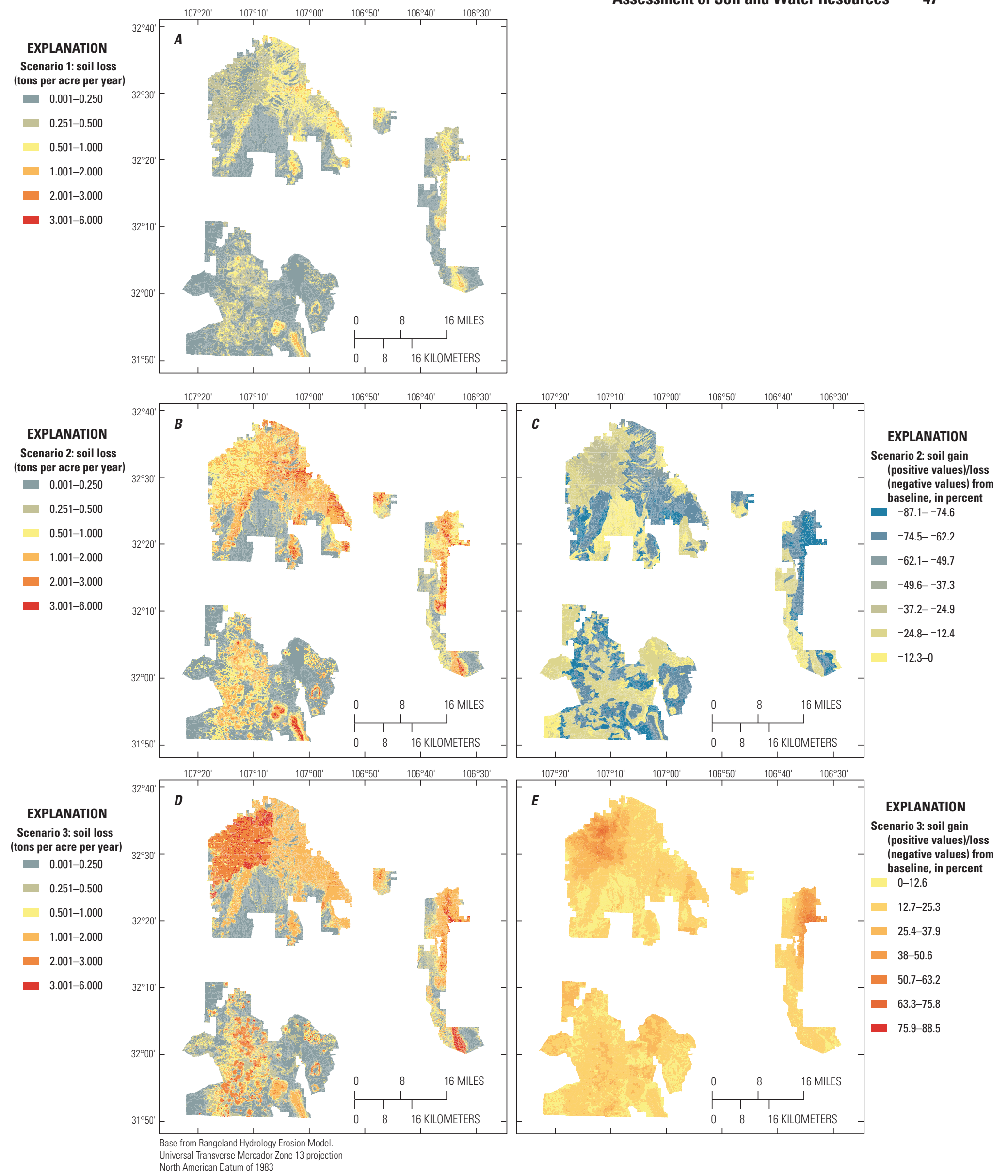

Figure 27. Soil loss and change from baseline scenario, Organ Mountains-Desert Peaks National Monument, New Mexico. A, Scenario 1: baseline soil loss. $B$, Scenario 2: soil loss. $C$, Scenario 2: change from baseline. $D$, Scenario 3: soil loss. $E$, Scenario 3: change from baseline. 


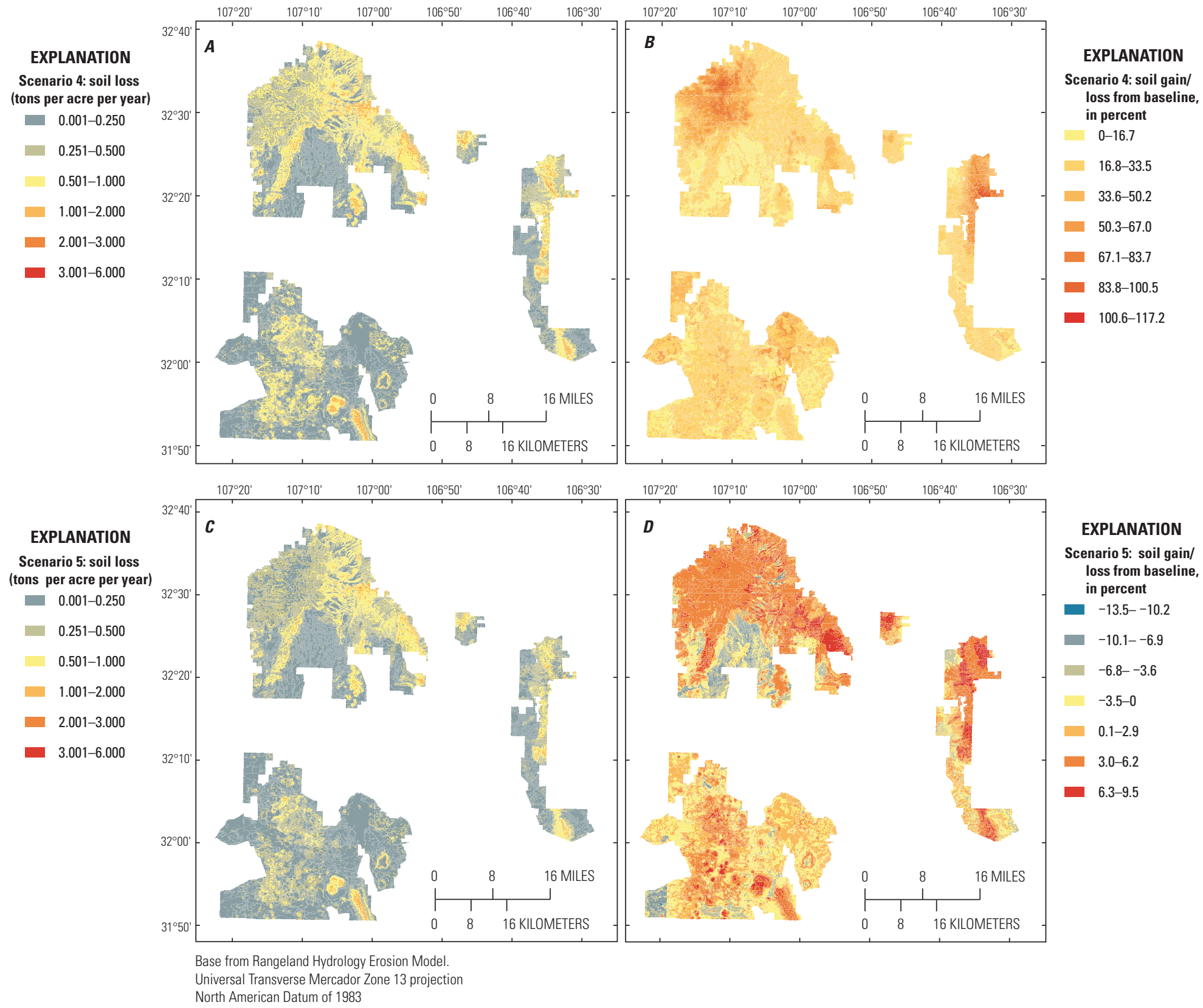

Figure 28. Soil loss and change from baseline scenario, Organ Mountains-Desert Peaks National Monument, New Mexico. A, Scenario 4: soil loss. B, Scenario 4: change from baseline. C, Scenario 5: soil loss. D, Scenario 5: change from baseline. 


\section{Estimated Runoff from RHEM Scenarios}

Annual average runoff across the Monument for the baseline conditions (Scenario 1) was $1.52 \mathrm{in} / \mathrm{yr}$. Annual average runoff was $1.29 \mathrm{in} / \mathrm{yr}$ in the North American Warm Desert Ruderal Scrub and Grassland (M512) macrogroup, $1.52 \mathrm{in} / \mathrm{yr}$ in the Chihuahuan Semi-Desert Grassland (M087) macrogroup, and $1.61 \mathrm{in} / \mathrm{yr}$ in the Chihuahuan Desert Scrub (M086) macrogroup.

Annual average runoff across the Monument for Scenario 2 (20-percent vegetation cover increase) was $0.69 \mathrm{in} / \mathrm{yr}$. Annual average runoff was $0.62 \mathrm{in} / \mathrm{yr}$ in the North American Warm Desert Ruderal Scrub and Grassland (M512) macrogroup, $0.76 \mathrm{in} / \mathrm{yr}$ in the Chihuahuan Semi-Desert Grassland (M087) macrogroup, and $0.65 \mathrm{in} / \mathrm{yr}$ in the Chihuahuan Desert Scrub (M086) macrogroup.

Annual average runoff across the Monument for Scenario 3 (20-percent vegetation cover decrease) was $1.62 \mathrm{in} / \mathrm{yr}$. Annual average runoff was $1.38 \mathrm{in} / \mathrm{yr}$ in the North American Warm Desert Ruderal Scrub and Grassland (M512) macrogroup, $1.64 \mathrm{in} / \mathrm{yr}$ in the Chihuahuan Semi-Desert Grassland (M087) macrogroup, and $1.70 \mathrm{in} / \mathrm{yr}$ in the Chihuahuan Desert Scrub (M086) macrogroup.

Annual average runoff across the Monument for Scenario 4 (drought, heavy grazing) was $1.60 \mathrm{in} / \mathrm{yr}$. Annual average runoff was $1.37 \mathrm{in} / \mathrm{yr}$ in the North American Warm Desert Ruderal Scrub and Grassland (M512) macrogroup, $1.63 \mathrm{in} / \mathrm{yr}$ in the Chihuahuan Semi-Desert Grassland (M087) macrogroup, and $1.67 \mathrm{in} / \mathrm{yr}$ in the Chihuahuan Desert Scrub (M086) macrogroup.

Annual average runoff across the Monument for Scenario 5 (shrub encroachment into grasslands) was $1.45 \mathrm{in} / \mathrm{yr}$. Annual average runoff was $1.24 \mathrm{in} / \mathrm{yr}$ in the North American Warm Desert Ruderal Scrub and Grassland (M512) macrogroup, $1.44 \mathrm{in} / \mathrm{yr}$ in the Chihuahuan Semi-Desert Grassland (M087) macrogroup, and $1.55 \mathrm{in} / \mathrm{yr}$ in the Chihuahuan Desert Scrub (M086) macrogroup.

\section{Simulated Soil Loss and Runoff from RHEM Scenarios}

Scenarios 2 and 3 (20-percent increase and 20-percent decrease in vegetation cover, respectively) were simulated to provide a theoretical upper and lower boundary of soil loss and runoff estimates for the Monument and represent a sensitivity analysis for vegetation cover (figs. 27, 29). The potential error associated with remotely sensed RHEM inputs, such as total foliar cover and ground cover, necessitates baseline estimates with a range of values for simulated soil loss and runoff. Scenarios 2 and 3 were included in this study to provide conservative estimates of soil loss and runoff for landmanagement purposes. Under this approach, annual average soil loss estimates for Scenarios 2 and 3 for the entire Monument were 0.19 and 0.45 (ton/acre)/yr, respectively, and average runoff estimates were 0.69 and $1.62 \mathrm{in} / \mathrm{yr}$ for Scenarios 2 and 3, respectively, for the entire Monument (table 14).

All scenarios except Scenario 5 (shrub encroachment) represent discreet changes in total foliar cover; Scenario 5 represents a proportional change in each of the individual vegetation categories while the total percentage of vegetation cover remains the same. Those scenarios involving manipulations of the total foliar cover resulted in the highest percentage of soil loss changes compared to the proportional manipulation of individual vegetation scenarios in Scenario 5 (figs. 28, 30). Given these results, RHEM-simulated soil loss is more heavily influenced by total foliar cover than by the individual vegetation category proportions. This finding is consistent with the $K_{s s}$ calculation procedure reported by Al-Hamdan and others (2017), which represents $K_{s s}$ as the major component in estimating soil loss. Examining individual vegetation categories separately provides only a modest increase in the amount of variation in $K_{s s}$ explained by the model. Variation in average runoff from baseline in scenarios that reduced (Scenarios 3 and 4) or manipulated (Scenario 5) vegetation cover was minimal (1.45 to $1.62 \mathrm{in} / \mathrm{yr},-4.1$ to 7.1 percent) (table 14$)$. When vegetation cover was increased (Scenario 2), average runoff from baseline was reduced dramatically ( $0.69 \mathrm{in} / \mathrm{yr},-54.4$ percent). This reduction is consistent with the $K_{e}$ (hydraulic conductivity) calculation, which is responsive to changes in the basal stem cover and litter cover and is the primary variable in RHEM-simulated runoff. The generally low vegetation cover of the Chihuahuan Desert results in minimal changes to runoff when cover is reduced or proportionally changed. However, a modest increase in vegetation cover (20-percent increase, Scenario 2) resulted in a large reduction in Monument runoff (table 14). 

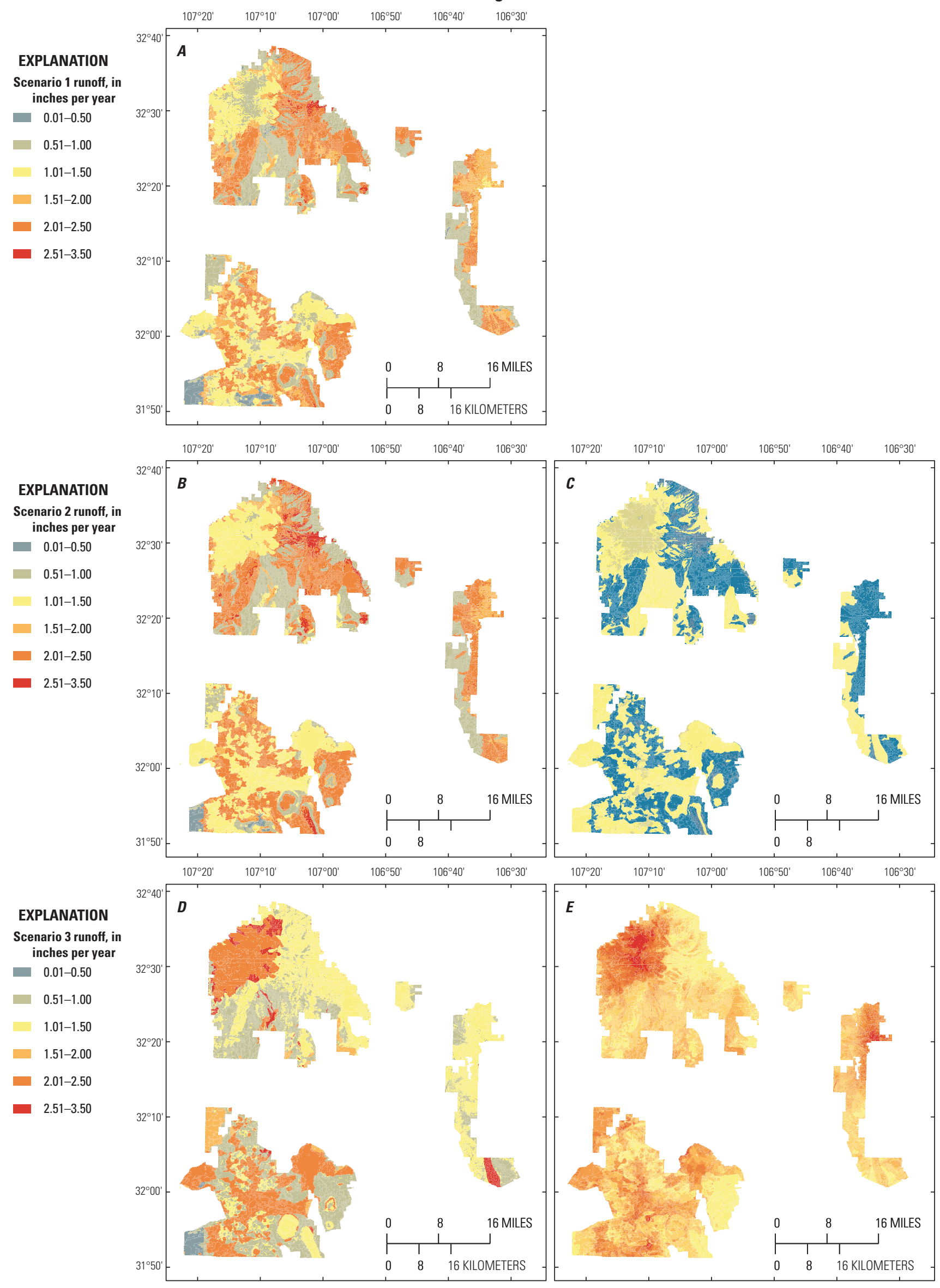

\section{EXPLANATION}

Scenario 2 runoff, change from baseline, in percent

$-87.1--74.6$

$-74.5--62.2$

$-62.1--49.7$

$-49.6--37.3$

$-37.2--24.9$

$-24.8--12.4$

$-12.3-0$

\section{EXPLANATION}

Scenario 3 runoff, change from baseline, in percent $0-4.9$

- $5-6.6$

$6.7-8.8$

- $8.9-11.5$

- $11.6-14.7$

- 14.8-19.0

19.1-48.5

Base from Rangeland Hydrology Erosion Model. Universal Transverse Mercador Zone 13 projection North American Datum of 1983

Figure 29. Runoff and change from baseline scenario, Organ Mountains-Desert Peaks National Monument, New Mexico. $A$, Scenario 1: baseline runoff. $B$, Scenario 2: runoff. $C$, Scenario 2: runoff change from baseline. $D$, Scenario 3: runoff. $E$, Scenario 3: runoff change from baseline. 


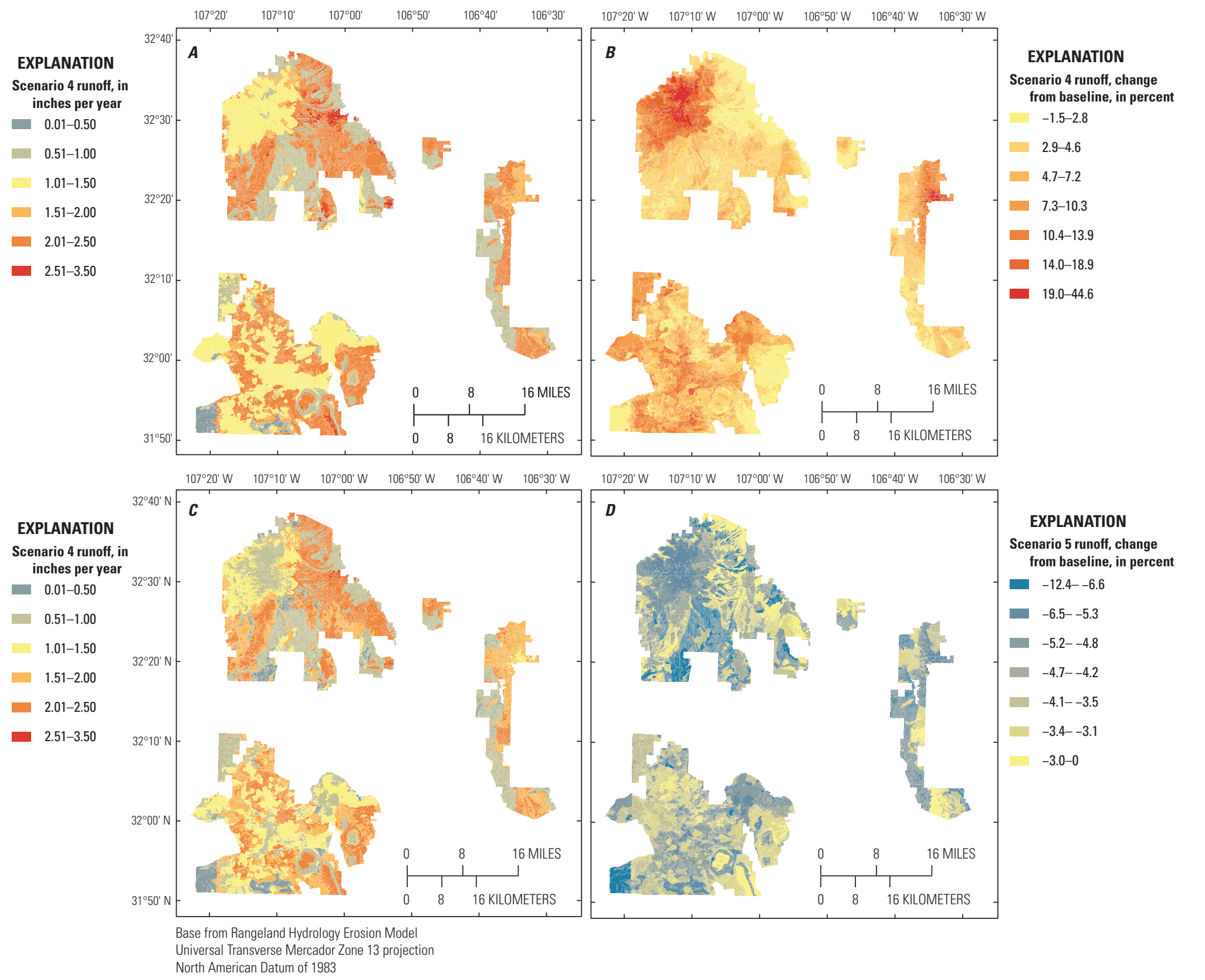

Figure 30. Runoff and percent change from baseline scenario, Organ Mountains-Desert Peaks National Monument, New Mexico. A, Scenario 4: baseline runoff. $B$, Scenario 4: percent runoff change from baseline. $C$, Scenario 5: runoff. $D$, Scenario 5: percent runoff change from baseline. 
Table 14. Slope percentage, cover percentage, soil loss, and runoff for the Organ Mountains-Desert Peaks National Monument, New Mexico, and for vegetation macrogroups with plots within the Monument.

[Vegetation macrogroups are defined in table 9. \%, percent; -, no data; \pm , plus or minus; (ton/acre)/yr, ton per acre per year; in/yr, inch per year]

\begin{tabular}{|c|c|c|c|c|c|c|c|c|c|c|c|c|}
\hline \multirow{4}{*}{ Scenario } & \multicolumn{6}{|c|}{ Total monument } & \multicolumn{2}{|c|}{ M086 } & \multicolumn{2}{|c|}{ M087 } & \multicolumn{2}{|c|}{ M512 } \\
\hline & \multicolumn{2}{|c|}{ Average slope \% } & 8 & - & - & - & 8.1 & - & 10.1 & - & 1.9 & - \\
\hline & \multicolumn{2}{|c|}{ Average cover \% } & 38.4 & - & - & - & 34.8 & - & 42.7 & - & 35.3 & - \\
\hline & $\begin{array}{c}\text { Average } \\
\text { soil loss } \\
\text { ([ton/acre]/yr) }\end{array}$ & \pm & $\begin{array}{c}\text { Average } \\
\text { soil loss } \\
\% \text { change }\end{array}$ & $\begin{array}{l}\text { Average } \\
\text { runoff } \\
\text { (in/yr) }\end{array}$ & \pm & $\begin{array}{c}\text { Average } \\
\text { runoff } \% \\
\text { change }\end{array}$ & $\begin{array}{c}\text { Average } \\
\text { soil loss } \\
\text { ([ton/acre]/yr) }\end{array}$ & $\begin{array}{l}\text { Average } \\
\text { runoff } \\
\text { (in/yr) }\end{array}$ & $\begin{array}{c}\text { Average } \\
\text { soil loss } \\
\text { ([ton/acre]/yr) }\end{array}$ & $\begin{array}{c}\text { Average } \\
\text { runoff } \\
\text { (in/yr) }\end{array}$ & $\begin{array}{c}\text { Average } \\
\text { soil loss } \\
\text { ([ton/acre]/yr) }\end{array}$ & $\begin{array}{c}\text { Average } \\
\text { runoff } \\
\text { (in/yr) }\end{array}$ \\
\hline 1 & 0.37 & 0.67 & - & 1.52 & 16.94 & - & 0.45 & 1.61 & 0.38 & 1.52 & 0.14 & 1.29 \\
\hline 2 & 0.19 & 0.35 & -49.3 & 0.69 & 7.75 & -54.4 & 0.21 & 0.65 & 0.20 & 0.76 & 0.08 & 0.62 \\
\hline 3 & 0.45 & 0.8 & 21.5 & 1.62 & 17.49 & 7.1 & 0.53 & 1.70 & 0.48 & 1.64 & 0.17 & 1.38 \\
\hline 4 & 0.48 & 0.86 & 30.9 & 1.60 & 17.26 & 5.6 & 0.56 & 1.67 & 0.53 & 1.63 & 0.17 & 1.37 \\
\hline 5 & 0.38 & 0.71 & 4.6 & 1.45 & 16.47 & -4.1 & 0.47 & 1.55 & 0.40 & 1.44 & 0.14 & 1.24 \\
\hline
\end{tabular}




\section{Assessment of Livestock Grazing}

RHEM estimates using Scenario 1, baseline conditions for the Monument, indicate that most soil loss occurs in the higher elevations of the Monument. Figure 31 shows watering troughs in the Monument with a quarter-mile buffer of increased grazing. Many of the troughs are within areas of prominent soil loss, as estimated by using RHEM. This soil loss can be attributed to a variety of factors including slope, rainfall, loss of vegetation, and general erosion. The presence of troughs and associated increased grazing in areas of relatively high soil loss may exacerbate existing conditions that contribute to high soil loss.

Baseline conditions for runoff simulated by the RHEM and locations of watering troughs within the Monument are shown in figure 32. Most troughs are in areas with moderate to high runoff. Model results indicate that runoff increases with decreased vegetation cover, which may occur because of the overgrazing that commonly occurs near watering troughs. High runoff tends to occur in areas with low available water capacity and in areas that have generally moderate to high soil loss. Grazing animals in these areas may contribute to the runoff problem by eating vegetation that would otherwise help to stabilize the soil and create less runoff.

\section{Assessment of Arroyo Location and Infiltration Potential}

The infiltration potential within the Monument can indicate areas with a lack of moisture-retentive soil. As shown in figure 33, arroyos tend to form in the Monument at higher elevations where there is a lower IPI value, and then the arroyos flow to the Rio Grande or lower valleys and flats.

Low infiltration potential in parts of the Monument leads to arroyo formation. In areas with low infiltration, relatively little runoff can be absorbed into the underlying soil; therefore, excess runoff may be concentrated into erosive, arroyoforming surface runoff. Many of these arroyos pass under or through roads and into the cities, such as Las Cruces, south of the Monument.

One of the largest arroyos in the area is the Placitas Arroyo (fig. 33), northwest of the Desert Peaks subunit. While not located in the Monument itself, this large arroyo has several smaller tributary arroyos that originate in the Desert Peaks subunit. The Placitas Arroyo flows directly into the Village of Hatch, where flooding from the Placitas Arroyo has been an issue (Korte, 2006); however, IPI values in the Desert Peaks subunit where some Placitas tributary arroyos originate are moderate to high. Runoff from that portion of the tributary arroyos within the Desert Peaks subunit therefore may not contribute substantially to flooding in the Placitas Arroyo. IPI calculations would have to be extended out of the Monument to determine other possible causes of flooding.

\section{Assessment of Roads and Trails}

Spatial analysis of the study area determined average road density to be $0.17 \mathrm{mi} / \mathrm{mi}^{2}$ for the entire Monument area, which is within the WCC Class 1 limit of $<1 \mathrm{mi} / \mathrm{mi}^{2}$. By subunit, road densities were $0.25 \mathrm{mi} / \mathrm{mi}^{2}$ for Desert Peaks, $0.09 \mathrm{mi} / \mathrm{mi}^{2}$ for Potrillo, $0.04 \mathrm{mi} / \mathrm{mi}^{2}$ for Doña Ana, and $0.17 \mathrm{mi} / \mathrm{mi}^{2}$ for Organ Mountains. For the entire Monument area, 28.8 percent of total road length was within $300 \mathrm{ft}$ of an ephemeral drainage (Class 3). By subunit, the percentages of total road length within $300 \mathrm{ft}$ of an ephemeral drainage were 32.9 percent (Class 3) for Desert Peaks, 16.9 percent (Class 2) for Potrillo, 72.8 percent (Class 3) for Doña Ana, and 26.9 percent (Class 3) for Organ Mountains (fig. 34). It is important to note that the Doña Ana subunit only has 0.59 mile of road.

Within the Monument boundary, available water capacity ranges from 0 to 30 in. (fig. 6). Available water capacity is critical for sustained plant life in this arid region. The disappearance of plants due to lack of soil moisture may result in erosion in the Monument, which can then be further accelerated by human activities such as building roads. Roads within this Monument generally fall within a moderately low water capacity area of about $2.4-4.7$ in. (6-12 cm) except for some roads in the Desert Peaks subunit that fall within a moderate range of 2.4-4.7 in. (12-18 cm) (figs. 6, 34). Erosion may be more likely to occur where roads exist in areas with little to no available water capacity. Available water capacity in the Potrillo subunit is also low to moderate. 


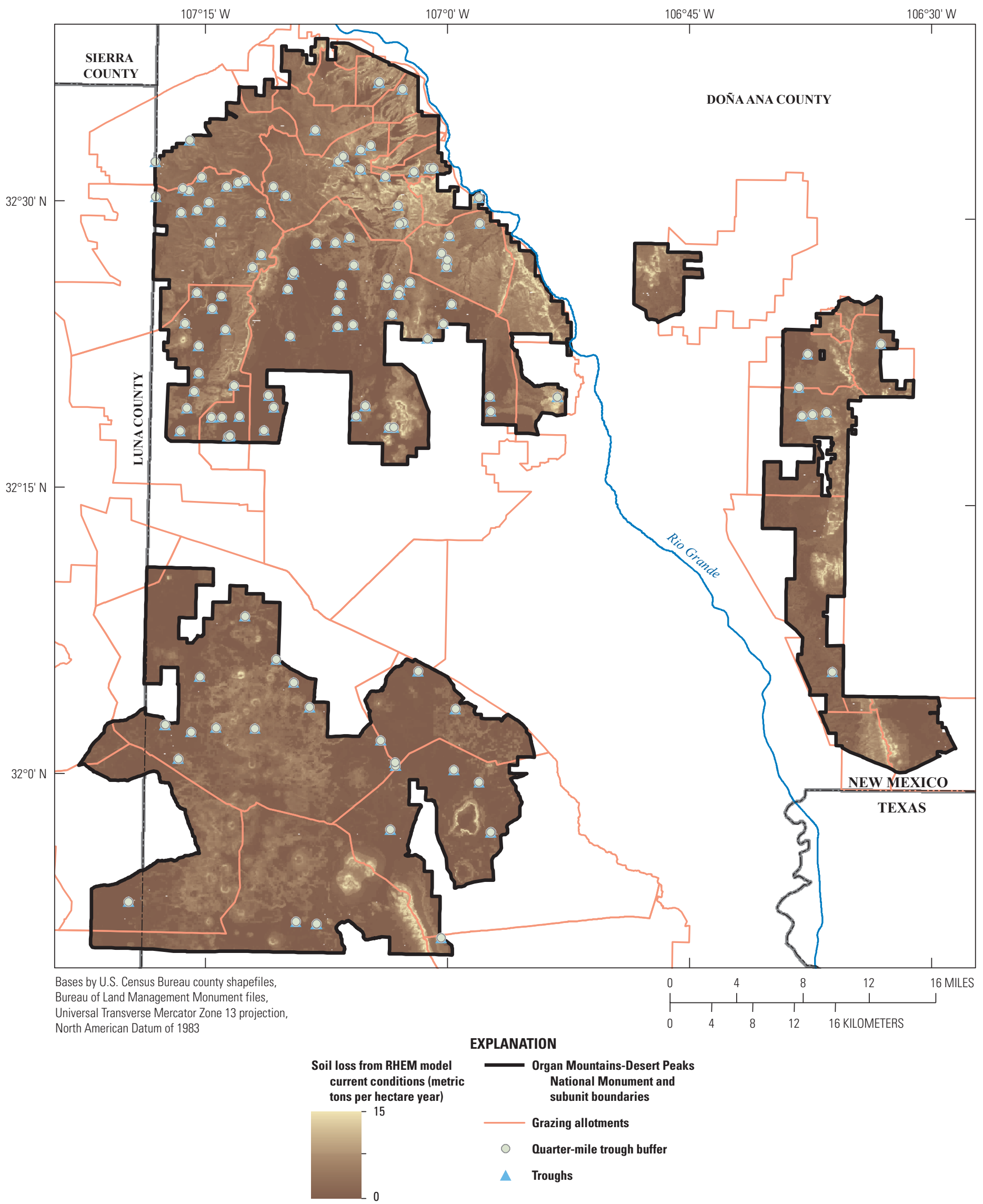

Figure 31. Watering trough locations and baseline soil loss conditions simulated by the Rangeland Hydrology and Erosion Model (RHEM), Organ Mountains-Desert Peaks National Monument, New Mexico. 


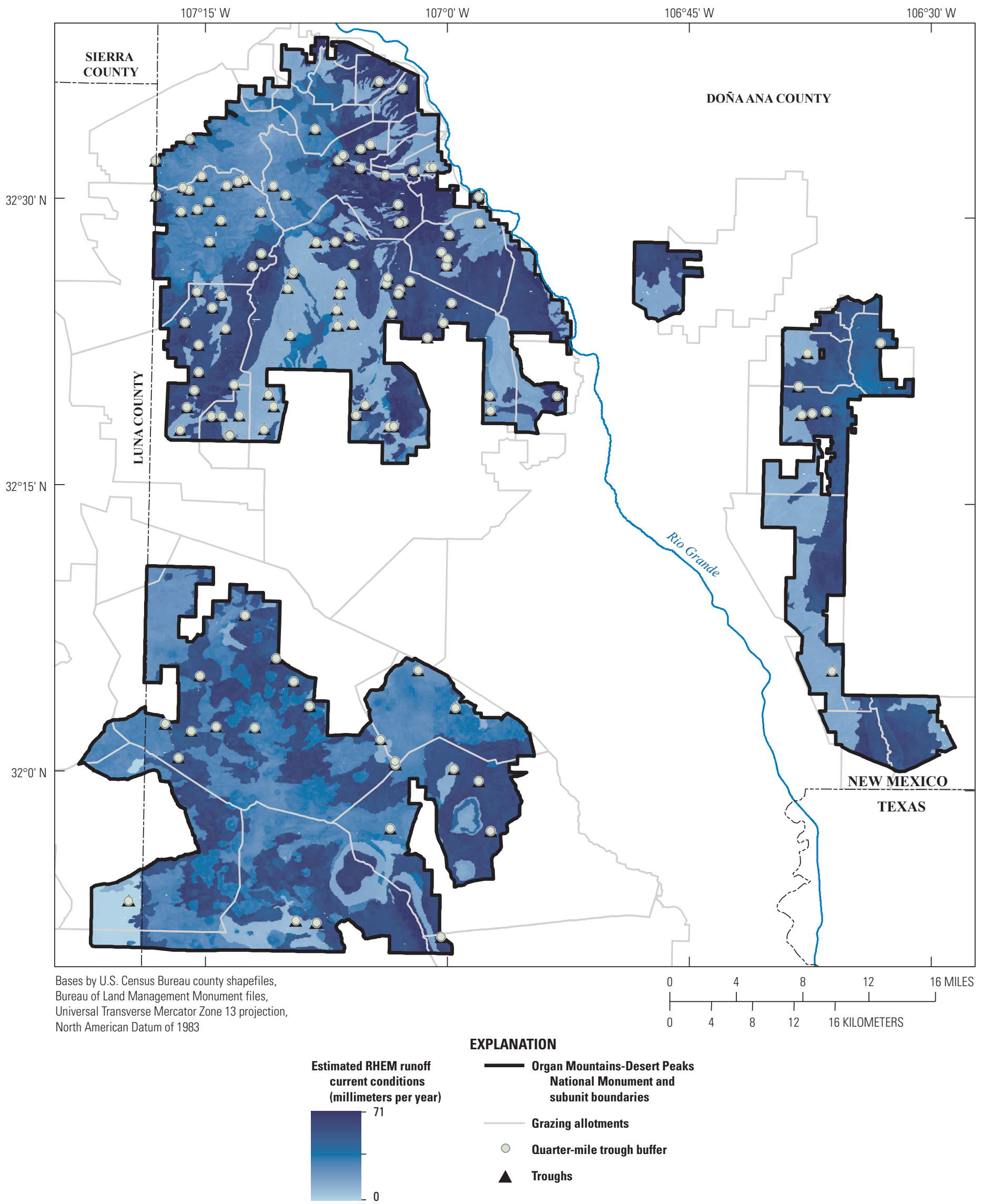

Figure 32. Watering trough locations and baseline runoff conditions simulated by the Rangeland Hydrology and Erosion Model (RHEM), Organ Mountains-Desert Peaks National Monument, New Mexico. 


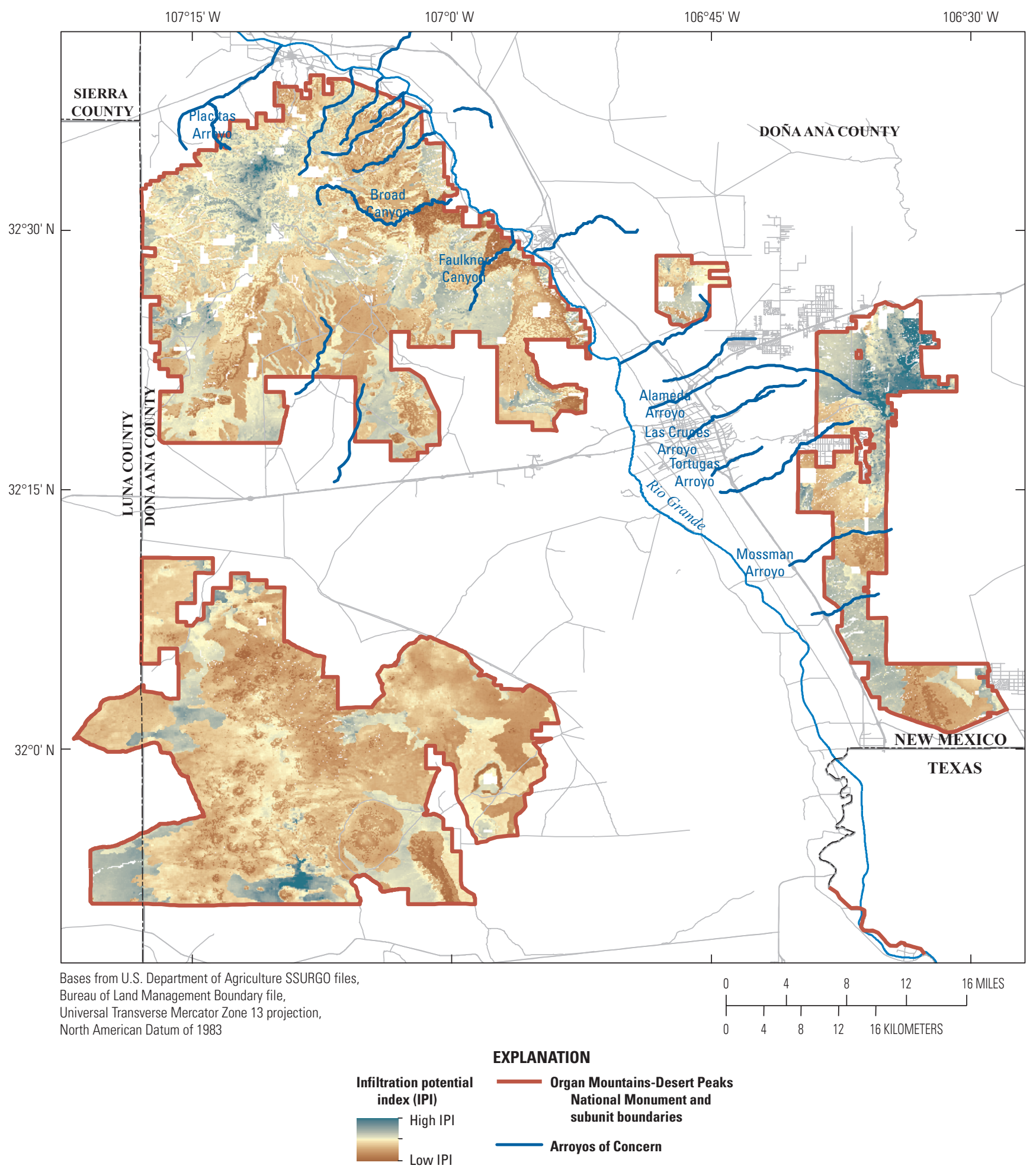

Figure 33. Location of arroyos of concern and infiltration potential in the Organ Mountains-Desert Peaks National Monument, New Mexico. 


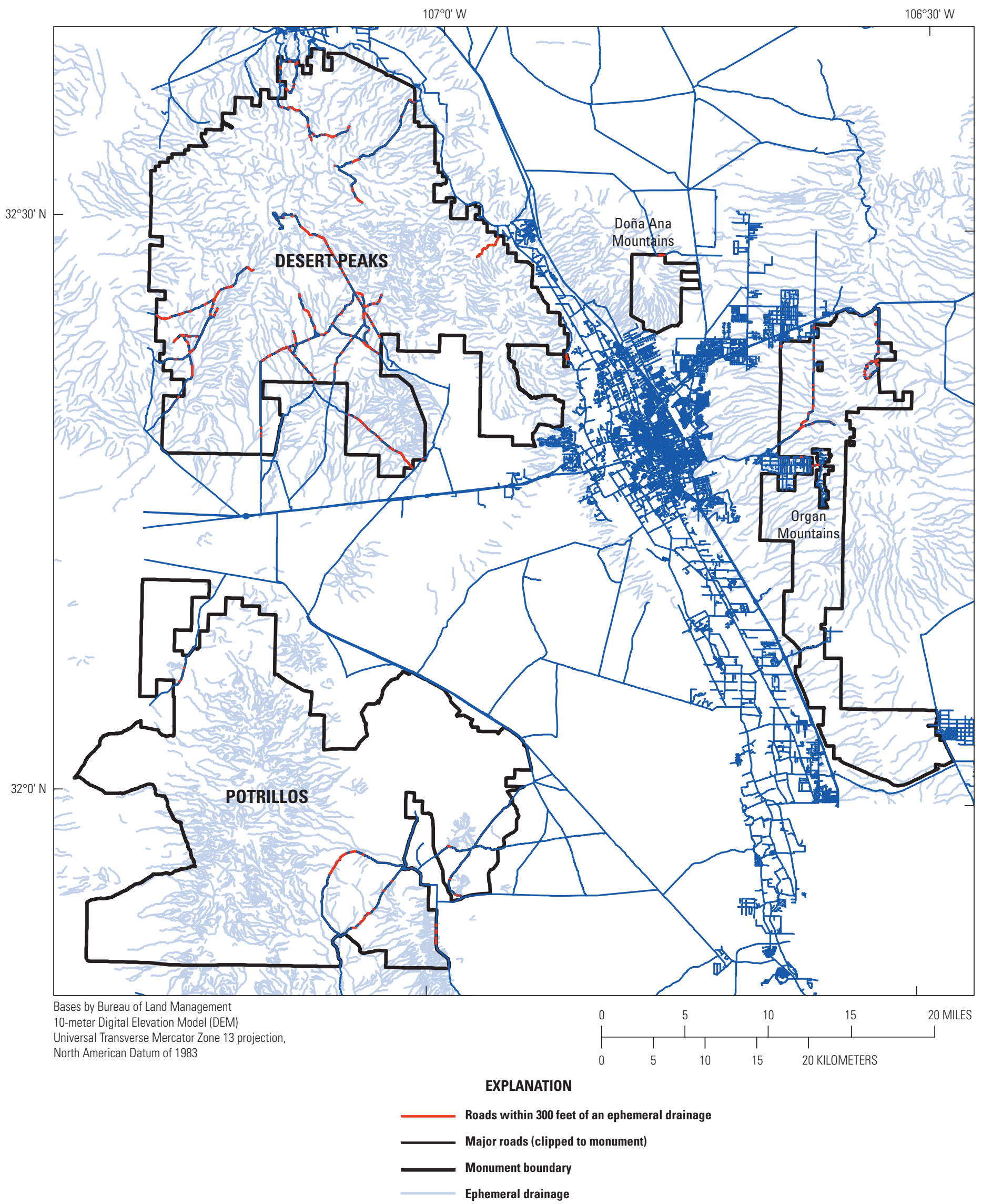

Figure 34. Location of major roads and roads within 300 feet of an ephemeral drainage in the Organ Mountains-Desert Peaks National Monument, New Mexico. 


\section{Assessment of Watershed Health}

The objective of this report was not specifically to evaluate watershed health, but the data and maps compiled and created here may provide initial understanding of overall health of the watersheds within the Monument. For example, the locations within the Monument with higher weathering potential like in the Organ Mountains, may have higher total dissolved solids or other water-quality constituents related to rock weathering. Groundwater and surface-water quality was not examined in this study, but locations of known wells (fig. 9) and surface-water channels (fig. 10) are included. There are multiple arroyos in the Organ Mountains subunit and the Desert Peaks subunit that flow from points of higher elevation towards the Rio Grande.

The climate of the region may affect a watershed through increased or reduced precipitation. Long-term changes in annual average precipitation can change vegetation patterns, rock weathering, water availability, and livestock grazing patterns. The maps provided in this report are a snapshot in time (all data available as of 2018) of these parameters.

The RHEM scenarios provide a simulated outlook of how soil loss and runoff might change based on changing parameters. Model results show locations in the Monument that may be more susceptible to soil loss and runoff. For example, in Scenario 2, the eastern sides of the Organ Mountains subunit and the Desert Peaks subunit show the highest runoff. However, in Scenario 3, the highest runoff is on the western side of the Desert Peaks subunit.

\section{Data Gaps Identified and Further Study Needs}

To enhance the understanding of soil and water resources in the Monument, additional data collection and study would improve modeling efforts. Future study would benefit from ground-truthing soils data and collection of additional soil information such as more detailed information in the subunits. If the soil data are incorrect or there are large gaps, then that inaccuracy can affect not only the actual soil types used in the modeling, but also the calculated estimates that rely on the soil data. There is a gap in the percentage of vegetation cover for the Potrillo subunit (fig. 4). Vegetation data can be collected by using unmanned aerial systems (UAS) across a broader area in a shorter time period than collecting data by using transects on the ground. By combining transect data and UAS data, a more robust vegetation dataset could be compiled. In addition, a long-term monitoring program of changing vegetation, erosion, and water availability would provide additional understanding of the effect of management decisions on the landscape.

It would be beneficial to view surface-water and groundwater resources together to fully understand the water resources in the Monument. The area has many groundwater wells (fig. 9), but most are inactive. Future studies could include analysis of groundwater resources and how different factors (climate, population growth, increased infrastructure, or change in grazing) might influence water availability and quality.

More detailed metadata of watering features in the Monument would assist in further understanding the effects of livestock or other animals on the Monument. In addition, information on the number and type of grazing animals per allotment would help to better explain the relation between livestock and model results for soil loss or changes in runoff.

\section{Summary}

The Organ Mountains-Desert Peaks National Monument (Monument) in southern New Mexico was established in 2014. Given anticipated future demands in the Monument for recreation, livestock grazing, and maintenance of rightsof-way (for example, pipelines and powerlines), the Bureau of Land Management (BLM) needs a better understanding of the current soil and water resources and how infrastructure improvements could affect these resources and the watershed. Specifically, the BLM is concerned with infiltration and erosion and their relations to existing or planned infrastructure, such as roads, campgrounds, location of livestock grazing, and rights-of-way. Alternatives to the current land-use conditions, land-management practices, and infrastructure will be assessed by BLM to best protect Monument resources. The U.S. Geological Survey, in cooperation with the Bureau of Land Management, conducted a study to assess the soil and water resources within the Monument to provide an inventory and compilation of natural-resource information needed by resource managers for the BLM's land-use planning process for this new national monument.

Data related to soil and water resources were collected and compiled for four subunits in the Monument: the Organ Mountains, the Doña Ana Mountains, the Desert Peaks (includes the Sierra de las Uvas and Robledo Mountains), and the Potrillo Mountains. These data were used to assess the relations among soils, vegetation, livestock, landforms, weathering, slope, infiltration, erosion, and runoff in the Monument. A series of maps was developed. The maps were created by combining spatial data in a geographic information system. Monument location, vegetation macrogroups, vegetation cover, soil texture classes, evapotranspiration, geology, well locations, surface-water features, current infrastructure, and grazing allotment maps are provided. Physical and chemical weathering potential maps and landform maps indicate locations where erosion and decreased infiltration may occur. In addition, the landform maps show specific locations of landform types that can be used to evaluate the addition of infrastructure in the Monument.

Five scenarios were simulated in the Rangeland Hydrology Erosion Model (RHEM) to calculate potential effects on 
runoff and erosion within the Monument based on changes in total foliar cover and changes to each foliar group (bunch grass, forbs, shrubs, and sod grass). The output from the RHEM scenarios provide information such as the effects of vegetation on model-estimated soil loss and runoff. This information, combined with results from infiltration potential indices, locations and types of landforms, weathering potential of rocks, water capacity, distance between roads and channels, and distance from water troughs, provides an array of spatial data in the Monument that can help management decisions related to soil and water resources in the Monument. Each map is included in the associated geodatabase (Mitchell and others, 2019; https://doi.org/10.5066/P9JVHA4Z), and maps can be overlain to identify areas of concern.

\section{References}

Al-Hamdan, O.Z., Pierson, F.B., Nearing, M.A., Williams, C.J., Hernandez, M., Boll, J., Nouwakpo, S.K., Weltz, M.A., and Spaeth, K., 2017, Developing a parameterization approach for soil erodibility for the Rangeland Hydrology and Erosion Model (RHEM): Transactions of the American Society of Agricultural and Biological Engineers, v. 60, no. 1, p. 85-94, accessed August 29, 2019, at https://doi. org/10.13031/trans.11559.

Anderson, E.W., 1986, A guide for estimating cover: Rangelands, v. 8, no. 5, p. 236-238.

Arguez, A., Durre, I., Applequist, S., Vose, R.S., Squires, M.F., Yin, X., Heim, R.R., Jr., and Owen, T.W., 2012, NOAA's 1981-2010 U.S. Climate Normals-An overview: Bulletin of the American Meteorological Society, v. 93, p. 1687-1697, accessed August 29, 2019, at https://doi. org/10.1175/BAMS-D-11-00197.1.

Arnáez, J., Larrea, V., and Ortigosa, L., 2004, Surface runoff and soil erosion on unpaved forest roads from rainfall simulation tests in northeastern Spain: Catena, v. 57, p. 1-14.

Baird, J.E., Floyd, W., Meerveld, I.V., and Anderson, A.E., 2012, Road surface erosion, part 1-Summary of effects, processes, and assessment procedures: Streamline Watershed Management Bulletin, v. 15, no. 1, p. 1-9.

Ball, G.P., and Douglas-Mankin, K.R., 2019, Geospatial scaling of runoff and erosion modeling in the Chihuahuan Desert: Applied Engineering in Agriculture, v. 35, no. 5, p. 733-743, accessed January 15, 2020, at https://doi. org/10.13031/aea.13275.

Belsky, A.J., Mwonga, S.M., Armundson, R.G., Duxbury, J.M., and Ali, A.R., 1993, Comparative effects of isolated trees on their undercanopy environments in high- and lowrainfall savannas: Journal of Applied Ecology, v. 30, no. 1, p. 143-155.
Bergkamp, G., 1998, A hierarchical view of the interactions of runoff and infiltration with vegetation and microtopography in semiarid shrublands: Catena, v. 33, no. 3-4, p. 201-220.

Bierman, P.R., and Montgomery, D.R., 2014, Key concepts in geomorphology (1st ed.): W.H. Freeman, 544 p.

Birkeland, P.W., ed., 1999, Soils and geomorphology: New York, Oxford University Press, 430 p.

Blackburn, W.H., 1983, Grazing impacts on watersheds: Rangelands, v. 5, no. 3, p. 123-125.

Bowen, N.L., 1922, The reaction principle in petrogenesis: Journal of Geology, no. 3, p. 177-198.

Brito, M.G., Costa, C.N., Almeida, J.A., Vendas, D., and Verdial, P.H., 2006, Characterization of maximum infiltration areas using GIS tools: Engineering Geology, v. 85, no. 1-2, p. 14-18, accessed August 29, 2019, at http://doi. org/10.1016/j.enggeo.2005.09.022.

Bureau of Land Management [BLM], 2018a, Organ Mountains-Desert Peaks National Monument, accessed February 8, 2018, at https://www.blm.gov/programs/national-conservation-lands/new-mexico/organ-mountains-desert-peaksnational-Monument.

Bureau of Land Management [BLM], 2018b, BLM and Forest Service announce 2018 grazing fees, accessed August 17, 2018, at https://www.blm.gov/press-release/blm-and-forestservice-announce-2018-grazing-fees.

Bureau of Land Management [BLM], 2019, National Environmental Policy Act, accessed February 26, 2019, at https:// www.blm.gov/programs/planning-and-nepa/what-informsour-plans/nepa.

Croke, J., Mockler, S., Fogarty, P., and Takken, I., 2005, Sediment concentration changes in runoff pathways from a forest road network and the resultant spatial pattern of catchment connectivity: Geomorphology, v. 68, p. 257-268.

Department of Primary Industries, Parks, Water and Environment, Tasmanian Government, 2014, Land Tasmania, Place naming in Tasmania, Rules and processes, Topographical features web page, accessed March 28, 2018, at http:// dpipwe.tas.gov.au/land-tasmania/place-naming-in-tasmania/ rules-and-processes/topographical-features.

Dikau, R., Brabb, E.E., and Mark, R.M., 1991, Landform classification of New Mexico by computer: U.S. Geological Survey Open-File Report 91-634, 16 p., accessed on February 8, 2018, at https://doi.org/10.3133/ofr91634.

Drever, J.I., 1994, The effect of land plants on weathering rates of silicate minerals: Geochemica et Cosmochimica Acta, v. 58, no. 10, p. 2325-2332. 
Dunne, T., Zhang, W., and Aubry, B.F., 1991, Effects of rainfall, vegetation, and microtopography on infiltration and runoff: Water Resources Research, v. 27, no. 9, p. 2271-2285.

EarthChem, 2018, EarthChem Portal, accessed November 18, 2018, at http://www.earthchem.org/portal.

Emenkie, H.I., Samson, S.A., Babalogbon, A.A., Adewoyin, J.E., Alaga, A.T., and Emenalom, O.O., 2016, Rangeland suitability for livestock grazing and economic implications in Irepodun area of Osun state Nigeria using remote sensing and GIS techniques: International Journal of Trend in Research and Development, v. 3, p. 189-195.

Eppes, M.C., McFadden, L.D., Wegmann, K.W., and Scuderi, L.A., 2010, Cracks in desert pavement rocks-Further insights into mechanical weathering by directional insolation: Geomorphology, v. 123 , no. 1-2, p. 97-108.

Esri, 2015, ArcGIS 10.4.1 for Desktop: Redlands, Calif., Environmental Systems Research Institute.

Flanagan, D.C., Frankenberger, J.R., and Ascough, J.C., II, 2012, WEPP - Model use, calibration, and validation: Transactions of the American Society of Agricultural and Biological Engineers, v. 55, no. 4, p. 1463-1477, accessed August 29, 2019, at https://doi.org/10.13031/2013.42254.

Flanagan, D.C., and Nearing, M.A., 1995, Water erosion prediction project-Hillslope profile and watershed model documentation: U.S. Department of Agriculture NSERL report, v. 10.

Gaines, L., Hemstrom, M., Kagan, J., and Salwasser, J., 2013, Integrated Landscape Assessment Project final report: Oregon State Institute for Natural Resources, 62 p., accessed December 1, 2017, at https://d2k78bk4kdhbpr.cloudfront. net/media/content/files/ILAP_final_report_sep9_2013.pdf.

Gibbens, R.P., and Beck, R.F., 1988, Changes in grass basal area and forb densities over a 64-year period on grassland types of the Jornada Experimental Range: Journal of Range Management, v. 41, no. 3, p. 186-192.

Gibbens, R.P., McNeely, R.P., Havstad, K.M., Beck, R.F., and Nolen, B., 2005, Vegetation changes in the Jornada Basin from 1858 to 1998: Journal of Arid Environments, v. 61, no. 4, p. 651-668.

Goldich, S.S., 1938, A study in rock weathering: Journal of Geology, v. 46, p. 17-58.

Glover, T.G., 1975, Geology of the central Organ Mountains Doña Ana County, New Mexico: New Mexico Geologic Society Guidebook, 26th Field Conference, p. 157-161.
GRASS Development Team, 2017, Geographic Resources Analysis Support System (GRASS) software: Open Source Geospatial Foundation, Electronic document v. 7.2, accessed August 29, 2019, at http://grass.osgeo.org.

Green, G.N., and Jones, G.E., 1997, The Digital Geologic Map of New Mexico in ARC/INFO Format: U.S. Geological Survey Open-File Report 97-0052, 9 p.; accessed August 6, 2019, at https://pubs.er.usgs.gov/publication/ofr9752.

Hajiaghaei, A., Rashidi, M., Sadeghi, M.A., Gholami, M., and Jaberinasab, B., 2014, Prediction of soil infiltration rate based on silt and clay content of soil: American-Eurasian Journal of Agriculture and Environmental Science, v. 14, no. 8, p. 702-706.

Harnois, L., 1988, The CIW index-A new chemical index of weathering: Sedimentary Geology, v. 55, p. 319-322.

Hawley, J.W., Hibbs, B.J., Kennedy, J.F., and Creel, B.J., 2001, The Mesilla Basin aquifer system of New Mexico, West Texas and Chihuahua-An overview of its hydrogeology framework and related aspects of aquifers of west Texas: Texas Water Development Board Report 356, p. 76-99, accessed April 12, 2018, at http://www.twdb. texas.gov/publications/reports/numbered_reports/doc/r356/ chapter7.pdf.

Helsel, D.R., and Hirsch, R.M., 2002, Statistical methods in water resources: U.S. Geological Survey Techniques of Water-Resources Investigations, book 4, chap. A3, 522 p.

Hernandez, M., Nearing, M.A., Al-Hamdan, O.Z., Pierson, F.B., Armendariz, G., Weltz, M.A., Spaeth, K.E., Williams, C.J., Nouwakpo, S.K., Goodrich, D.C., Unkrich, C.L., Nichols, M.H., and Holifield Collins, C.D., 2017, The Rangeland Hydrology and Erosion Model-A dynamic approach for predicting soil loss on rangelands: Water Resources Research, v. 53, no. 11, p. 9368-9391, accessed August 29, 2019, at https://doi.org/10.1002/2017WR020651.

Herrick, J.E., Van Zee, J.W., Havstad, K.M., Burkett, L.M., and Whitford, W.G., 2005a, Monitoring manual for grassland, shrubland and savanna ecosystems, volume I-Quick start: USDA-ARS Jornada Experimental Range, $44 \mathrm{p}$.

Herrick, J.E., Van Zee, J.W., Havstad, K.M., Burkett, L.M., and Whitford, W.G., 2005b, Monitoring manual for grassland, shrubland, and savanna ecosystems, volume IIDesign, supplementary methods and interpretations: USDAARS Jornada Experimental Range, 206 p.

Hoffer, J.M., 2001, Geology of the West Potrillo Mountains, in Crumpler, L.S., and Lucas, S.G., eds., Volcanology in New Mexico: New Mexico Museum of Natural History and Science Bulletin 18, p. 141-145. 
Holechek, J.E., Tembo, A., Daniel, A., Fusco, M.J., and Cardenas, M., 1994, Long-term grazing influences on Chihuahuan Desert rangeland: The Southwestern Naturalist, v. 39, no. 4, p. 342-349.

Horton, R.E., 1933, The role of infiltration in the hydrologic cycle: Transactions of the American Geophysical Union, v. 14 , p. $446-460$.

Horton, R.E., 1940, An approach towards physical interpretation of infiltration capacity: Proceedings of the Soil Science Society of America, v. 5, p. 399-417.

Hubbard, R.K., Newton, G.L., and Mill, G.M., 2004, Water quality and the grazing animal: Journal of Animal Science, v. 82, p. E255-E236.

Huggett, R.J., 2007, Fundamentals of geomorphology (2d ed.): Routledge Fundamentals of Physical Geography, 483 p.

Jasiewicz, J., and Stepinski, T.F., 2012, Geomorphons-A pattern recognition approach to classification and mapping of landforms: Geomorphology, v. 182, p. 147-156.

Khumalo, G., and Holechek, J., 2005, Relationships between Chihuahuan desert perennial grass production and precipitation: Rangeland Ecology and Management, v. 58, no. 3, p. 239-246.

Kilburn, J.E., Stoeser, D.B., Zimbelman, D.R., Hanna, W.F., and Gese, D.D., 1988, Mineral resources of the West Potrillo Mountains-Mount Riley and the Aden Lava Flow Wilderness Study Areas, Dona Ana and Luna Counties, New Mexico: U.S. Geological Survey Bulletin 1735-B, accessed August 29, 2019, at https://doi.org/10.3133/b1735B.

Korte, Tim, 2006, Crews drain water from flooded N.M. town: Washington Post, August 17, 2006, accessed December 10, 2018, at http:/www.washingtonpost.com/ wp-dyn/content/article/2006/08/16/AR2006081600512_ pf.html?noredirect $=$ on.

Mabbutt, J.A., 1977, Desert landforms: An introduction to systematic geomorphology v. 2, 340 p.

Malm, N.R., 2003, Climate guide, Las Cruces, 1892-2000: New Mexico State University, Agricultural Experiment Station, Research Report 749, 27 p., accessed January 25, 2018, at http://aces.nmsu.edu/pubs/research/weather_ climate/RR749.pdf.

Mankin, K.R., Ward, A.D., and Boone, K.M., 1996, Quantifying changes in soil physical properties from soil and crop management-A survey of experts: Transactions of the American Society of Agricultural and Biological Engineers, v. 39, no. 6, p. 2065-2074.
McCalla, G.R., II, Blackburn, W.H., and Merrill, L.B., 1984, Effects of livestock grazing on infiltration rates, Edwards Plateau of Texas: Journal of Range Management, v. 37, no. 3, p. 265-269, accessed January 25, 2018, at https:// www.jstor.org/stable/3899153.

McFadden, L.D., Eppes, M.C., Gillespie, A.R., and Hallet, B., 2005, Physical weathering in arid landscapes due to diurnal variation in the direction of solar heating: GSA Bulletin, v. 117, no. 1-2, p. 161-173, accessed August 29, 2019, at https://doi.org/10.1130/B25508.1.

McIntyre, D.S., 1958, Soil splash and the formation of surface crusts by raindrop impact: Soil Science, v. 85, p. 261-266.

Megahan, W.F., and Ketcheson, G.L., 1996, Predicting downslope travel of granitic sediments from forest roads: Idaho Water Resources Bulletin, v. 32, p. 371-382.

Mitchell, A.C., Shephard, Z.M., Blake, J.M., Ball, G.P., Chavarria, S.B., and Douglas-Mankin, K.R., 2019, Database associated with the assessment of soil and water resources in the Organ Mountains-Desert Peaks National Monument: U.S. Geological Survey data release, https://doi. org/10.5066/P9JVHA4Z.

Morgan, J.M., III, and Lesh, A.M., 2005, Developing landform maps using ESRI's ModelBuilder: Towson University, 11 p., accessed March 1, 2019, at http://proceedings.esri.com/ library/userconf/proc05/papers/pap2206.pdf.

Morino, K.A., 1996, Reconstruction and interpretation of historical patterns of fire occurrence in the Organ Mountains, New Mexico: University of Arizona, Thesis, 144 p.

National Aeronautics and Space Administration [NASA], 2015, ASTER Global Digital Elevation Model 30 meters: NASA EOSDIS Land Processes DAAC, USGS Earth Resources Observation and Science (EROS) Center, accessed January 17, 2017, at https://search.earthdata.nasa. gov/search.

National Oceanic and Atmospheric Administration [NOAA], 2018, Climate data online search: NOAA National Centers for Environmental Information, accessed January 15, 2018, at https://www.ncdc.noaa.gov/cdo-web/search.

Natural Resources Conservation Service [NRCS], 1998, Soil quality resource concerns-Available water capacity: U.S. Department of Agriculture, accessed August 8, 2018, at https://www.nrcs.usda.gov/Internet/FSE_DOCUMENTS/ nrcs142p2_051279.pdf. 
Natural Resources Conservation Service [NRCS], 2009, Chapter 7, Hydrologic soil groups: U.S. Department of Agriculture, Part 630 Hydrology National Engineering Handbook (2010-VI-NEH), accessed November 18, 2018, at https:// www.wcc.nrcs.usda.gov/ftpref/wntsc/H\&H/NEHhydrology/ ch7.pdf.

Natural Resources Conservation Service [NRCS], 2017a, Gridded soil survey geographic (gSSURGO) database for State name: U.S. Department of Agriculture, accessed December 1, 2017, at https://gdg.sc.egov.usda.gov/.

Natural Resources Conservation Service [NRCS], 2017b, U.S. General Soil Map (STATSGO2): U.S. Department of Agriculture, accessed December 1, 2017, at https://sdmdataaccess.sc.egov.usda.gov.

Natural Resources Conservation Service [NRCS], 2018, National soil survey handbook, title 430-VI: U.S. Department of Agriculture, accessed March 28, 2018, at http://www.nrcs.usda.gov/wps/portal/nrcs/detail/soils/ ref/?cid=nrcs142p2_054242.

Nearing, M.A., Wei, H., Stone, J.J., Pierson, F.B., Spaeth, K.E., Weltz, M.A., Flanagan, D.C., and Hernandez, M., 2011, A rangeland hydrology and erosion model: Transactions of the American Society of Agricultural and Biological Engineers, v. 54, no. 3, p. 901-908, accessed November 23, 2017, at https://doi.org/10.13031/2013.37115.

Nesbitt, H.W., and Young, G.M., 1982, Early Proterozoic climates and plate motions inferred from major element chemistry of lutites: Nature, v. 299, p. 715-717.

New Mexico Office of the State Engineer/Interstate Stream Commission [NMOSE/ISC], 2018, Statewide Groundwater Level Monitoring Program, accessed October 11, 2018, at http://www.ose.state.nm.us/Hydrology/groundWater.php.

Parker, A., 1970, An index of weathering for silicate rock: Geological Magazine, v. 107, p. 501-504.

Pei, X., and Bin, F., 2011, The runoff characteristics under simulated rainfall on purple soil sloping cropland: Chinese Journal of Geochemistry, v. 30, p. 317, accessed August 29, 2019, at https://doi.org/10.1007/s11631-011-0515-5.

Potyondy, J.P., and Geier, T.W., 2011, Watershed condition classification technical guide: U.S. Department of Agriculture, Forest Service, FS-978, accessed November 18, 2018, at https://www.fs.fed.us/biology/resources/pubs/watershed/ maps/watershed_classification_guide2011FS978.pdf.

Price, J.R., and Velbel, M.A., 2003, Chemical weathering indices applied to weathering profiles developed on heterogeneous felsic metamorphic parent rocks: Chemical Geology, v. 20, p. 397-416, accessed August 29, 2019, at https://doi. org/10.1016/j.chemgeo.2002.11.001.
Reiche, P., 1943, Graphic representation of chemical weathering: Journal of Sediment Petrology, v. 13, p. 58-68.

Roaldset, E., 1972, Mineralogy and geochemistry of Quaternary clays in the Numedal area, southern Norway: Norwegian Journal of Geology, v. 52, p. 335-369.

RStudio, 2015, RStudio-Integrated development for R: Boston, Mass., RStudio, Inc., accessed November 27, 2018, at http://www.rstudio.com/.

Sampaio de Almeida, W., Panachuki, E., Tarso Sanches de Oliveira, P., da Silva Menezes, R., Alves Sobrinho, T., and Fonseca de Carvalho, D., 2018, Effect of soil tillage and vegetal cover on soil water infiltration: Soil and Tillage Research, v. 175, p. 130-138, accessed August 29, 2019, at http://dx.doi.org/10.1016/j.still.2017.07.009.

Seager, W.R., 1995, Geology of southwest quarter of Las Cruces and northwest El Paso $1^{\circ} \times 2^{\circ}$ sheets, New Mexico: New Mexico Bureau of Mines and Mineral Resources, Geologic Map 60.

Seager, W.R., Clemons, R.E., and Hawley, J.W., 1976, Geology of Sierra Alta quadrangle, Doña Ana County, New Mexico: New Mexico Bureau of Mines and Mineral Resources, Bulletin 102.

Seager, W.R., Clemons, R.E., Hawley, J.W., and Kelley, R.E., 1982, Geology of northwest part of Las Cruces $1^{\circ}$ x $2^{\circ}$ sheet, New Mexico: New Mexico Bureau of Mines and Mineral Resources, Geologic Map 53.

Seager, W.R., Hawley, J.W., Kottlowski, F.E., and Kelley, S.A., 1987, Geology of east half of Las Cruces and northeast El Paso $1^{\circ}$ x $2^{\circ}$ sheets, New Mexico: New Mexico Bureau of Mines and Mineral Resources, Geologic Map 57.

Selby, M.J., 1993, Hillslope materials and processes ( 2 d ed.): New York, Oxford University Press, 451 p.

Senay, G.B., Friedrichs, M., Singh, R.K., and Velpuri, N.M., 2016, Evaluating Landsat 8 evapotranspiration for water use mapping in the Colorado River Basin: Remote Sensing of Environment, v. 185, p. 171-185, accessed August 29, 2019, at https://doi.org/10.1016/j.rse.2015.12.043.

Seutloali, K.E., and Beckedahl, H.R., 2015, A review of roadrelated soil erosion-An assessment of causes, evaluation techniques and available control measures: Earth Science Research Journal, v. 19, no. 1, p. 73-80.

Sharma, K.D., 1997, Assessing the impact of overgrazing on soil erosion in arid regions at a range of spatial scales: Human Impact on Erosion and Sedimentation, Proceedings of the Rabat Symposium, April 1997, 1 1Q IAHS no. 245. 
She, D.L., Fei, Y.H., Liu, Z.P., Liu, D.D., and Shao, G.C., 2014, Soil erosion characteristics of ditch banks during reclamation of a saline/sodic soil in a coastal region of China-Field investigation and rainfall stimulation: Catena, v. 121, p. 176-185.

Sheng, Z., 2013, Impacts of groundwater pumping and climate variability on groundwater availability in the Rio Grande Basin: Ecosphere, v. 4, no. 1, p. 1-25, accessed August 16, 2018, at https://doi.org/10.1890/15-0938.1.

Spinelli, R., and Marchi, E., 1996, A literature review of the environmental impacts of forest road construction: Proceedings of the Seminar on Environmentally Sound Forest Roads and Wood Transport: Food and Agriculture Organization of the United Nations, accessed November 19, 2018, at http://www.fao.org/docrep/X0622E/x0622e0p.htm.

Teeple, A.P., 2017, Geophysics- and geochemistry-based assessment of the geochemical characteristics and groundwater-flow system of the U.S. part of the Mesilla Basin/ Conejos-Médanos aquifer system in Doña Ana County, New Mexico, and El Paso County, Texas, 2010-12: U.S. Geological Survey Scientific Investigations Report 2017-5028, 183 p., accessed August 29, 2019, at https://doi.org/10.3133/ sir20175028.

Terracon, John Shomaker and Associates, Inc., Livingston Associates, LLC., Inc., Zia Engineering and Environmental, Inc., and Sites Southwest, 2003, The New Mexico Lower Rio Grande regional water plan: New Mexico Office of State Engineers, 216 p., accessed August 16, 2018, at http://www.ose.state.nm.us/Planning/RWP/Regions/11 LRG/1999/LOWER-RIO-GRANDE-REGIONAL-WAT̄ERPLAN.pdf.

The Jornada, 2016, Database for Inventory, Monitoring and Assessment (DIMA), accessed August 6, 2019, at https:// jornada.nmsu.edu/monit-assess/dima.

The White House Office of the Press Secretary, 2014, Establishment of the Organ Mountains-Desert Peaks National Monument: Presidential Proclamation, accessed March 8, 2018, at https://obamawhitehouse.archives.gov/the-pressoffice/2014/05/21/presidential-proclamation-organ-mountains-desert-peaks-national-Monument.

Thornton, P.E., Thornton, M.M., Mayer, B.W., Wei, Y., Devarakonda, R., Vose, R.S., and Cook, R.B., 2016, Daymet: Daily surface weather data on a 1-km grid for North America: Oak Ridge, Tennessee, ORNL DAAC, v. 3, accessed July 1, 2018, at https://doi.org/10.3334/ORNLDAAC/1328.

Undersander, D., Albert, B., Cosgrove, D., Johnson, D., and Peterson, P., 2002, Pastures for profit - A guide to rotational grazing: University of Wisconsin-Madison A3529, 38 p.
U.S. Climate Data, 2018, Climate Las Cruces-New Mexico, accessed January 15, 2018, at https:/usclimatedata.com/ climate/las-cruces/new-mexico/united-states/usnm0492.

U.S. Department of Agriculture, Agricultural Research Service, Southwest Watershed Research Center [USDA-ARSSWRC], 2013, Rangeland Hydrology and Erosion Model web tool, accessed October 20, 2017, at https://apps.tucson. ars.ag.gov/rhem/.

U.S. Geological Survey [USGS], 2014, USGS 1:1,000,000scale federal lands of the United States 201412 shapefile: National Atlas of the United States, accessed August 29, 2019, at https://www.sciencebase.gov/catalog/ item/5d150464e4b0941bde5b7654.

U.S. Geological Survey [USGS], 2018a, Earth Explorer, accessed November 19, 2018, at https://earthexplorer. usgs.gov/.

U.S. Geological Survey [USGS], 2018b, Geographic Names Information System (GNIS), accessed November 19, 2018, at http://geonames.usgs.gov/apex/f?p=gnispq.

U.S. Geological Survey [USGS], 2018c, National Water Information System Mapper, accessed November 19, 2018, at http://dx.doi.org/10.5066/F7P55KJN. [Mapper directly accessible at https://maps.waterdata.usgs.gov/mapper/ index.html].

U.S. Geological Survey [USGS], 2018d, The National Map, accessed January 17, 2018, at https://viewer.nationalmap. gov/basic/?basemap=b1\&category $=$ ned,nedsrc\&title $=3 \mathrm{DEP}$ percent20View.

U.S. Geological Survey [USGS], 2019, Evapotranspiration and the water cycle, accessed March 1, 2019, at https:// water.usgs.gov/edu/watercycleevapotranspiration.html.

U.S. National Vegetation Classification [USNVC], 2017, U.S. National Vegetation Classification Database, v. 2.01, Federal Geographic Data Committee, accessed on January 17, 2018, at http://usnvc.org/explore-classification./.

Vincent, C.H., 2017, Livestock grazing in Organ Mountains-Desert Peaks National Monument: Congressional Research Service Memorandum, 7-5700, accessed May 5, 2018, at https://www.organmountains.org/wp-content/ uploads/2017/07/OMDPNM-Grazing-Final-Memo_ CRS_2017.pdf.

Vogel, D.E., 1975, Precambrian weathering in acid metavolcanic rocks from the Superior Province, Villebon Township, south-central Quebec: Canadian Journal of Earth Sciences, v. 12, p. 2080-2085.

Webb, N.P., Herrick, J.E., and Duniway, M.C., 2014, Ecological site-based assessments of wind and water erosionInforming accelerated soil erosion management in rangelands: Ecological Applications, v. 24, no. 6, p. 1405-1420. 
Wilson, M.J., 2004, Weathering of the primary rock-forming minerals - Processes, products and rates: Clay Minerals, v. 39, p. 233-266, accessed August 29, 2019, at https://doi. org/10.1180/0009855043930133.

World Landforms, 2015, World landforms, accessed June 15, 2017, at http://worldlandforms.com/landforms/list-of-alllandforms/.

Zhang, X.C., and Garbrecht, J.D., 2003, Evaluation of CLIGEN precipitation parameters and their implication on WEPP runoff and erosion prediction: Transactions of the ASAE, v. 46, no. 2, p. 311-320, accessed August 29, 2019, at https://doi.org/10.13031/2013.12982.

Zhuang, X., Wang, W., Ma, Y., Huang, X., and Lei, T., 2018, Spatial distribution of sheet flow velocity along slope under simulated rainfall conditions: Geoderma, v. 321, p. 1-7, accessed August 29, 2019, at https://doi.org/10.1016/j. geoderma.2018.01.036.

For more information about this publication, contact

Director, New Mexico Water Science Center

U.S. Geological Survey

6700 Edith Blvd NE

Albuquerque, New Mexico 87113

For additional information, visit

https://www.usgs.gov/centers/nm-water

Publishing support provided by

Lafayette Publishing Service Center 



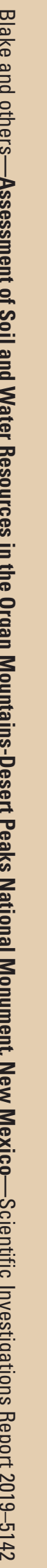

